TOM ALEXANDRE BRANDÃO

\title{
CONTRIBUIÇÃO AO ESTUDO DAS OBRIGAÇÕES PROPTER REM E INSTITUTOS CORRELATOS
}

Dissertação de mestrado em Direito Civil Orientação: Professora Titular Teresa Ancona Lopez

Faculdade de Direito da Universidade de São Paulo Departamento de Direito Civil 
Agradeço à professora Teresa Ancona Lopez pela orientação, paciência e, sobretudo, amizade ao longo desses anos de intenso convívio. Além dos profundos conhecimentos jurídicos - os quais são notórios e inerentes à posição que ocupa - impressiona a humildade e generosidade no trato com os seus alunos, desde o primeiro ano da graduação. É um exemplo que busco seguir em minha vida. 


\section{RESUMO}

A presente dissertação tem como objeto o estudo das obrigações propter rem e figuras correlatas.

Os grandes civilistas dedicaram-se ao tema que será desenvolvido neste trabalho; o assunto não é inédito, muito ao contrário. Contudo, vários pontos permanecem controversos, até mesmo quanto à própria definição e alcance da noção de obrigação real.

A importância da matéria não se resume a uma discussão acadêmica, meramente abstrata. Em realidade, o instituto é extremamente recorrente na doutrina e jurisprudência.

Ocorre que, considerada a confusão conceitual que caracteriza essa espécie de obrigação, verifica-se que o instituto serve de fundamento a diversas decisões, muitas delas sem precisão técnica necessária.

Decerto, criam-se vínculos e deveres sem que exista uma lei específica nesse sentido, sob o simples argumento de que se trata de uma obrigação propter rem. Não bastasse, são atribuídos determinados efeitos a essas obrigações, os quais não são necessariamente essenciais ao instituto.

Nesse contexto, consideramos que uma releitura do conceito de obrigação real é oportuna e pode contribuir para um tratamento mais adequado de uma série de questões. 


\begin{abstract}
This dissertation discusses the propter rem obligations and related legal aspects.

The propter rem obligations are not a new topic and it was studied by all main civil law scholars. However, there are a many unsolved matters related to such obligations, including its exact definition and extension.
\end{abstract}

The relevance of propter rem obligations is not limited to an academic debate; in fact it is a recurring matter by commentators and court precedents.

Due to the conceptual misunderstanding as to the correct definition of propter rem obligations, this concept has been mistakenly used in several court decisions.

Courts are creating legal obligations without proper legislation, based solely on the argument that such obligations are based on the propter rem principles, including the attribution of supposed legal effects not related to these obligations.

In this context, we believe it is important to revisit the concept of the propter rem obligations to promote a better understanding of several issues. 


\section{SUMÁRIO}

INTRODUÇÃO

PARTE I

\section{CAPÍTULO ÚNICO: ASPECTOS GERAIS DOS DIREITOS REAIS}

1. Conceito e conteúdo dos direitos reais 10

2. Os princípios e as características fundamentais dos direitos reais 12

$\begin{array}{ll}\text { 2.1. Sequela } & 12\end{array}$

2.2. Preferência ou prevalência $\quad 13$

$\begin{array}{ll}\text { 2.3. Perpetuidade } & 14\end{array}$

2.4. Eficácia absoluta (oponibilidade erga omnes) 15

$\begin{array}{ll}\text { 2.5. A taxatividade e a tipicidade } & 16\end{array}$

2.6. Outras características $\quad 19$

3. Classificação dos direitos reais 20

3.1. Direitos reais de gozo 20

3.2. Direitos reais de garantia 22

3.3. Direito real de aquisição 22

4. Distinção entre os direitos reais e pessoais 23

\section{PARTE II}

\section{CAPÍTULO I: OBRIGAÇÕES PROPTER REM}

1. Conceito de obrigações reais 29

2. Dos fundamentos das obrigações propter rem 31

3. Breves considerações acerca da origem histórica das obrigações reais $\quad 33$

4. Sujeitos da obrigação real 34

5. A terminologia empregada 36

6. A natureza jurídica da obrigação propter rem 37

7. O conteúdo das obrigações reais 40

8. A controvérsia a respeito dos direitos reais in faciendo 41

9. A taxatividade das obrigações reais 45

10. Transmissão da obrigação propter rem: ambulatoriedade 47

11. Renúncia liberatória e abandono 53

11.1. Aspectos gerais $\quad 53$

11.2. Das conseqüências da renúncia em relação às obrigações propter rem 55 


\section{CAPÍTULO II: OUTRAS SITUAÇÕES CONSIDERADAS HÍBRIDAS}

1. Obrigações com eficácia real 60

1.1. Considerações gerais $\quad 60$

1.2. A obrigação com eficácia real não é uma obrigação propter rem 62

2. Ônus real

2.1. Acepções da expressão ônus e distinções necessárias 63

2.2. Da noção de ônus real $\quad 65$

2.3. Distinção entre ônus real e obrigação propter rem 68

PARTE III

\section{CAPÍTULO I: CONTRIBUIÇÕES CONDOMINIAIS}

1. O dever do condômino de participar do custeio do condomínio 70

2. A transmissão da propriedade e a contribuição condominial

3. Noção de condômino: legitimidade passiva e aspectos processuais 74

4. A preferência do crédito condominial 76

5. Condomínios irregulares e atípicos 77

CAPÍTULO II: DIREITO AMBIENTAL

1. Breves considerações acerca da responsabilidade civil objetiva 84

2. O caráter objetivo da responsabilidade civil ambiental 86

3. Princípios da responsabilidade civil ambiental 88

4. A reparação ambiental como obrigação propter rem 89

CAPÍTULO III: IMPOSTOS SOBRE PROPRIEDADE IMOBILIÁRIA

1. Classificação dos tributos. Impostos reais e pessoais 94

2. Noções gerais sobre IPTU 95

3. Sucessão da responsabilidade tributária 97

4. O IPTU como ônus real 98

CAPÍTULO IV: OUTRAS SITUAÇÕES

1. Direitos de vizinhança

1.1. Considerações gerais 100

1.2. Direitos de vizinhança como obrigação propter rem 101

2. Servidões 105

3. Usufruto

3.1. Considerações gerais 108

3.2. Os deveres e obrigações impostos ao usufrutuário 109

CONCLUSÕES

BIBLIOGRAFIA 


\section{INTRODUÇÃO}

Para a correta apreensão da noção de obrigação propter rem é necessária uma análise, ainda que não aprofundada, das principais características dos direitos das coisas.

Decerto, a obrigação propter rem está intimamente relacionada aos direitos reais, na medida em que decorre justamente da titularidade de uma situação jurídica do direito das coisas.

Assim, consideramos imprescindível o conhecimento dos aspectos mais importantes dos direitos reais; abordaremos, também, as diferenças essenciais entre os direitos pessoais e reais, pois a matéria é bastante útil à conceituação e natureza das obrigações propter rem.

Essas questões serão desenvolvidas na primeira parte da dissertação.

A segunda parte, que constitui a essência do nosso trabalho, tratará dos fundamentos teóricos das obrigações reais e institutos correlatos.

Pretendemos atualizar o conceito de obrigação real, destacando as suas características mais importantes. Envidaremos esforços para estabelecer critérios que permitam identificar se determinada relação jurídica pode, ou não, ser considerada uma obrigação propter rem.

Trataremos dos atributos que geralmente são associados às obrigações reais, em especial quanto à origem legal (taxatividade), transmissibilidade (ambulatoriedade) e possibilidade de exoneração pela renúncia.

Um ponto de destaque em nossa dissertação diz respeito à diferenciação das obrigações reais e situações jurídicas assemelhadas; é o que ocorre com os ônus reais e as obrigações com eficácia real. 
Não raro, essas expressões são utilizadas de forma indiscriminada pela doutrina e jurisprudência, como se sinônimos fossem, em prejuízo à boa técnica.

A terceira parte é dedicada a uma análise detida nas hipóteses mais corriqueiras de obrigações reais.

Abordaremos a contribuição condominial em seus diversos aspectos; serão discutidas a noção de condômino e as conseqüências da transmissão da propriedade em relação às dívidas condominiais pendentes.

Outrossim, trataremos de importante questão debatida em nossos tribunais a respeito da contribuição em condomínios irregulares ou de fato. Para tanto, importa verificar se essas despesas realmente podem ser cobradas pelas associações de moradores e, em caso positivo, se aderem ao imóvel na hipótese de transmissão da propriedade.

As obrigações propter rem têm destaque em matéria ambiental.

É o que acontece, por exemplo, na responsabilidade civil por danos ao meio ambiente. Há acórdãos da lavra do Superior Tribunal de Justiça que estabelecem a obrigação do atual proprietário de área desmatada em promover a recuperação, mesmo que não tenha sido ele o causador da degradação.

Ainda que se admita a importância e o interesse social que motivam essas decisões, é preciso questionar se tal obrigação é realmente propter rem, ao menos segundo os critérios estabelecidos pela nossa doutrina.

Os impostos cujo fato gerador consistem na propriedade de bem imóvel (IPTU e ITR) são comumente considerados pela doutrina obrigações propter rem ou ônus reais. 
Serão analisadas a natureza dessa espécie de tributo, a noção de contribuinte e, ainda, a sucessão tributária e suas conseqüências em relação aos débitos fiscais em aberto.

Por fim, serão também abordadas outras hipóteses associadas às obrigações reais, tais como os direitos de vizinhança, as servidões e o usufruto. 


\section{CAPÍTULO ÚNICO: ASPECTOS GERAIS DOS DIREITOS REAIS}

\section{Conceito e conteúdo dos direitos reais}

Os direitos reais expressam uma verdadeira ideologia e demonstram a forma como a sociedade civil se organiza e se estrutura ${ }^{1}$.

Consistem, na definição de Clóvis Beviláqua, no complexo de normas reguladoras das relações jurídicas referentes às coisas suscetíveis de apropriação pelo homem ${ }^{2}$. Em termos mais simples, tratam das relações existentes entre os homens e as coisas.

Arnoldo Wald destaca que o direito das coisas "se caracteriza por um colorido profundamente nacional, sendo marcado por sua época" ${ }^{3}$.

É antiga a discussão a respeito da terminologia apropriada. Os alemães usam a designação Sachenrecht, que pode ser traduzida como direito das coisas. Em Portugal predomina a expressão direitos reais ${ }^{4}$.

Para José de Oliveira Ascensão, os direitos reais "são direitos absolutos, inerentes a uma coisa e funcionalmente dirigidos à afectação desta aos interesses do sujeito" 5 .

\footnotetext{
${ }^{1}$ Para Orlando Gomes (Direitos Reais, p. 16), "o Direito das Coisas entende diretamente com a organização social porque regula o poder dos homens sobre os bens e as formas de sua utilização econômica. É a estrutura das fortunas privadas que a ordem jurídica informa, disciplinando o fim da atividade econômica individual".

${ }^{2}$ Direito das Coisas, p. 9. Os bens imateriais, a exemplo dos direitos autorais, são disciplinados em leis especiais. O Código Civil só disciplina, no Livro do Direito das Coisas, os bens materiais ou corpóreos. Há, ademais, uma série de leis especiais que são inseridas no conceito do Direito das Coisas, a exemplo da legislação sobre loteamentos.

${ }^{3}$ Curso de Direito Civil Brasileiro - Direito das Coisas, p. 16. E, portanto, afirma que o intérprete deve admitir com reservas as lições do direito estrangeiro sobre a matéria.

${ }^{4}$ Entre nós, o Código Civil de 2002 manteve a denominação direito das coisas, que já prevalecia no Código anterior. Para Luciano de Camargo Penteado (Direito das Coisas, p. 72), a expressão direito das coisas é mais ampla, pois abrange também o fenômeno da posse. Decerto, fundamenta o autor, a posse não é caracterizada como direito real pelo artigo 1.225 do Código Civil. Em nosso trabalho, usaremos as expressões direitos reais e direitos das coisas indistintamente.

${ }^{5}$ Direito Civil - Reais, p. 44.
} 
Não são todos os bens que interessam ao direito das coisas, mas apenas aqueles úteis à satisfação de necessidades pelo homem.

Do mesmo modo, os bens de extrema abundância (o ar atmosférico e a luz solar como usualmente exemplifica a doutrina) não são abrangidos pelo direito das coisas, pois inexiste interesse econômico que justifique a sua regulação.

Miguel Maria de Serpa Lopes ressalta que a coisa, para consistir em objeto de um direito, deve apresentar os seguintes pressupostos: a) ser representada por um objeto capaz de satisfazer um interesse econômico; b) ser suscetível de gestão econômica autônoma; c) ter capacidade para ser objeto de uma subordinação jurídica ${ }^{6}$.

O caráter corpóreo como requisito necessário à configuração de uma situação jurídica real gera polêmica. No Código Civil de 1916 havia um capítulo, no Livro do Direito das Coisas, que tratava da propriedade literária, artística e científica.

Todavia, consideradas as especificidades desses direitos, notadamente pela íntima relação com os direitos extrapatrimoniais, tornou-se necessário um regramento específico $^{7}$.

A lei admite, excepcionalmente, a existência de direitos reais sobre bens incorpóreos ${ }^{8}$. Os casos mais importantes são o usufruto sobre universalidades e os direitos de garantia sobre direitos ou títulos de crédito.

É importante ressaltar, como será desenvolvido ao longo deste trabalho, que a relação jurídica real não implica apenas poderes e direitos do sujeito sobre a coisa objeto do direito, mas também gera deveres ${ }^{9}$.

\footnotetext{
${ }^{6}$ Curso de Direito Civil - Direito das Coisas, p. 40.

${ }^{7}$ Cf. Lei 5.988/72 e, posteriormente, a Lei $\mathrm{n}^{\circ}$ 9.610/98.

${ }^{8}$ É a opinião de Orlando Gomes (Op. cit., p. 20): "Objeto de direito real podem ser tanto as coisas corpóreas como as incorpóreas. Sua limitação às primeiras não se justifica. É reconhecida a existência de direitos sobre direitos, que são bens incorpóreos. Admite-se que o usufruto e o penhor possam ser objeto de outro direito real. Discute-se, porém, sobre a possibilidade de ter um direito por objeto um direito pessoal. Admitido que o usufruto e o penhor podem recair em créditos, que são direitos pessoais, nenhuma dúvida subsiste para uma resposta afirmativa. Desde que o poder do titular se exerça diretamente sobre um crédito, em intermediário, como se exerce sobre uma coisa corpórea, o direito é de natureza real". Distinta é a posição de Serpa Lopes, para quem é impossível que um direito tenha por objeto outro direito (Op. cit., p. 50).
} 


\section{Os princípios e as características fundamentais dos direitos reais}

A doutrina ressalta a sequela e a preferência como as características distintivas dos direitos reais ${ }^{10}$.

Serpa Lopes, nessa linha de pensamento, sustenta que os direitos de sequela e de preferência representam as duas grandes superioridades do direito real sobre o direito de crédito ${ }^{11}$.

2.1 Sequela ${ }^{12}$

Também chamada de perseguição ou seguimento, a sequela permite ao titular de direito real seguir a coisa em poder de todo e qualquer detentor ou possuidor ${ }^{13}$.

Está diretamente relacionada à aderência (ou inerência) dos direitos reais; significa que o conteúdo do direito real é projetado sobre a coisa que constitui o seu objeto.

Como sustenta Luís A. Carvalho Fernandes, a sequela é a manifestação dinâmica da inerência dos direitos reais: "por ser inerente a ela (coisa), o direito muda, em geral, se passar a recair sobre coisa diversa; em contrapartida, acompanha a coisa nas suas vicissitudes" 14 .

\footnotetext{
${ }^{9}$ A esse respeito, confira-se o conceito de direito real apresentado por Manuel Henrique Mesquita, respeitado professor português, autor de obra imprescindível ao estudo das obrigações propter rem: "direito real é a relação jurídica através da qual uma coisa fica directamente subordinada ao domínio ou soberania de uma pessoa, segundo certo estatuto, que constitui a fonte não apenas dos poderes que assistem ao respectivo titular, mas também dos deveres que sobre ele impendem" (Obrigações Reais e Ónus Reais, p. 55).

${ }^{10}$ Oliveira Ascensão critica severamente a doutrina latina que dá grande ênfase ao estudo da sequela e da preferência, meras consequências da noção de direito real, negligenciando a análise do tema das pretensões reais (Op. cit., p. 621).

${ }^{11}$ Op. cit., 29.

${ }^{12}$ Explica Menezes Cordeiro (Direito Reais, p. 317) que "a idéia de sequela, já antiga, foi muito utilizada em França, como fruto do labor dos seguidores da formulação clássica: explicava-se que sendo o direito real um poder directo e imediato sobre a coisa, podia atingi-la ainda que ela estivesse nas mãos de terceiro. Era, então, designada de droit de suite, tendo passado a Itália como diritto di seguito". Para os franceses, ainda seguindo o autor, a sequela não seria um direito, mas apenas uma característica ou faculdade específica do direito real.

${ }^{13} \mathrm{O}$ direito é estampado na parte final do artigo 1.228 do Código Civil: "O proprietário tem a faculdade de usar, gozar e dispor da coisa, e o direito de reavê-la do poder de quem quer que injustamente a possua ou detenha".

${ }^{14}$ Lições de Direitos Reais, p. 67.
} 
Numa expressão metafórica, o direito real adere à coisa como a lepra ao corpo (uti lepra cuti) ${ }^{15}$.

Observa Oliveira Ascensão que apenas os direitos reais têm sequela ${ }^{16}$. A característica é peculiar a toda espécie de direito real e pode voltar-se, inclusive, contra o proprietário $^{17}$.

Para Menezes Cordeiro, usualmente os direitos reais são exercidos por meios materiais, de sorte que a sequela só surge como manifestação patológica, isto é, quando o titular é obrigado a recorrer a meios jurídicos para reaver a coisa ${ }^{18}$.

\subsection{Preferência ou prevalência ${ }^{19}$}

Restrito aos direitos reais de garantia, consiste no privilégio de obter o pagamento de uma dívida com o valor do bem aplicado exclusivamente à sua satisfação ${ }^{20}$.

Nesse passo, uma vez constituído o direito real de garantia, a responsabilidade da obrigação se concentra sobre determinado bem do patrimônio do devedor, excluindo o direito de outros credores que tenham apenas direito pessoal ou, ainda, direito real com inscrição posterior.

Miguel Maria de Serpa Lopes afirma que a preferência pode ser compreendida em dois aspectos: temporal e espacial ${ }^{21}$.

\footnotetext{
${ }^{15}$ Orlando Gomes (Direitos Reais, p. 19). Para Carlos Roberto Gonçalves (Direito Civil Brasileiro, Vol. V, p. 13) "a aderência do direito real à coisa não é senão a constatação do fato de que o direito real permanece incidindo sobre o bem, ainda que este circule de mão em mão e se transmita a terceiros, pois o aludido direito segue a coisa (jus persequendi)".

${ }^{16}$ Op. cit., p. 625.

${ }^{17}$ Miguel Maria de Serpa Lopes, Op. cit., p. 29.

${ }^{18}$ op. cit., p. 319. Não é o que ocorre, diz o autor, nos direitos reais de garantia e aquisição, nos quais o exercício é jurídico e a sequela se manifesta habitualmente.

${ }^{19}$ Luís A. Carvalho Fernandes sustenta que a designação preferência deve ser evitada, pois tem sentido técnico preciso, qual seja, a faculdade obrigacional ou real reconhecida a alguém de ser preferido a terceiros na aquisição de um direito (Op. cit. p. 70).

${ }^{20}$ É expresso no artigo 1.419: "Nas dívidas garantidas por penhor, anticrese ou hipoteca, o bem dado em garantia fica sujeito, por vínculo real, ao cumprimento da obrigação".

${ }^{21}$ Op. cit., p. 30.
} 
O primeiro é restrito ao âmbito dos direitos reais de garantia. Em caso de conflito entre dois direitos reais de igual conteúdo, mas de titulares diversos, prevalece aquele que for inscrito em primeiro lugar.

A ordem espacial significa que o bem onerado com a garantia deverá ser alienado e o produto da venda, utilizado, prioritariamente, para o pagamento do titular do direito real correspondente.

José de Oliveira Ascensão afirma que a prevalência é uma consequência do direito real, que se apresenta como distintiva dos direitos reais e dos créditos ${ }^{22}$.

Menezes Cordeiro se opõe à prevalência do direito real sobre o direito de crédito e argumenta que, com a constituição do direito real, o direito de crédito se extinguiria pela impossibilidade do seu objeto.

\subsection{Perpetuidade}

Os direitos reais tendem à perpetuidade. Nas palavras de Luciano de Camargo Penteado, possuem forte disposição para permanecer na esfera jurídica do titular $^{23}$.

Pela perpetuidade entende-se que o direito real não se perde pela falta de uso, mas apenas pelos meios e formas legais. Nesse particular, diferenciam-se dos direitos pessoais, que, em regra, são instantâneos.

A. Santos Justo rejeita essa característica, pois considera que há direitos reais temporários, tal como o usufruto, e outros que se extinguem pelo exercício, como os direitos reais de garantia. Assim, a perpetuidade não seria uma característica dos direitos reais, mas apenas uma tendência ${ }^{24}$.

\footnotetext{
${ }^{22}$ Op. cit., p. 630.

${ }^{23}$ Op. cit., p. 89.

24 Direitos Reais, p. 23/24. Nesse mesmo sentido, Oliveira Ascensão (Op. cit. p. 622). Realmente, a característica expressa uma tendência, mas admite exceções. O direito real do promitente comprador de imóvel (artigo 1.225 do Código Civil) é temporário, pois em regra é extinto com a transmissão da propriedade (é o seu objetivo). Em relação aos direitos pessoais, a obrigação de não fazer tem característica de permanência.
} 


\subsection{Eficácia absoluta (oponibilidade erga omnes)}

O absolutismo está relacionado ao caráter erga omnes do direito real, que pode ser exercido contra todos. Há um dever de abstenção imposto à coletividade: todos são obrigados a respeitar o direito, se abstendo de qualquer ato que impeça ou dificulte o seu exercício pelo respectivo titular.

Na lição de Arnoldo Wald, a distinção entre os direitos absolutos e os direitos relativos remonta ao direito romano, na classificação das ações então existentes entre reais e pessoais ${ }^{25}$.

Há quem considere o absolutismo uma característica essencial à definição dos direitos reais. Todavia, ainda que aceita a premissa de que existem direitos absolutos, é forçoso reconhecer que tal circunstância não é exclusiva dos direitos reais, abrangendo outros, tais como os direitos da personalidade ${ }^{26}$.

Oliveira Ascensão faz uma análise por exclusão e explica que direitos absolutos são os direitos não relativos, isto é, aqueles que são independentes de uma relação particular ${ }^{27}$.

Serpa Lopes assevera que a oponibilidade do direito real não é sempre absoluta e frequentemente ela pode ser restrita aos terceiros que tiveram ou puderam ter conhecimento do direito ${ }^{28}$.

\footnotetext{
${ }^{25}$ Op. cit., p. 23: "As primeiras (reais), como a reivindicação, se referiam à coisa pretendida, enquanto as segundas, como a ação de cobrança, continham, nas fórmulas, o nome do devedor de quem se exigia determinada prestação. Os juristas romanos conheceram pois as ações em que o réu estava devidamente identificado como pessoa (ações pessoais) e outras que visavam conseguir ou obter certo objeto, sem cuidar do sujeito passivo, fazendo-se a reivindicação contra quem tivesse a coisa em seu poder (ações reais)”.

${ }^{26}$ Novamente é oportuna a lição de Arnoldo Wald (Op. cit., p. 24): "Quando os direitos absolutos defendem bens que estão na própria pessoa do seu titular são denominados direitos da personalidade. (...) Quando os bens protegidos são exteriores à pessoa do titular do direito e o dever jurídico recai sobre todos os outros homens, os direitos absolutos são denominados direitos reais. São direitos absolutos, por não terem sujeito passivo indeterminado, e são reais, pois seu objeto não está na personalidade do titular (sujeito ativo) mas numa coisa, numa res”.

${ }^{27}$ Op. cit., p. 46. Em suas próprias palavras: "há direitos que não assentam em relação alguma. Os seus titulares têm uma posição absoluta, porque é garantida pela ordem jurídica, independentemente de qualquer relação particular. Por isso, são válidos erga omnes - no sentido de que podem ser feitos valer potencialmente contra qualquer um. A relação surgirá acessoriamente na vida destes direitos, mas não é constitutiva deles".

${ }^{28}$ Op. cit., p. 28.
} 
Essa característica, contudo, perde sua importância, pois a moderna doutrina reconhece que mesmos os direitos pessoais, considerados relativos, devem ser respeitados por todos.

Nessa linha de raciocínio, todos os direitos seriam dotados de oponibilidade absoluta $^{29}$.

\subsection{A taxatividade e a tipicidade}

Vigora, entre nós, o sistema do numerus clausus, de modo que os direitos reais são taxativamente enumerados na $1 \mathrm{ei}^{30}$.

Conforme esclarece Gustavo Tepedino, o princípio do numerus clausus "se refere à exclusividade de competência do legislador para a criação de direitos reais, os quais, por sua vez, possuem conteúdo típico, daí resultando um segundo princípio, corolário do primeiro, o da tipicidade dos direitos reais, segundo o qual o estabelecimento de direitos reais não pode contrariar a estruturação dos poderes atribuídos ao respectivo titular" ${ }^{31}$.

Assim, prossegue o autor, embora aparentemente coincidentes, o "numerus clausus" e a tipicidade "diferenciam-se na medida em que o primeiro diz respeito à fonte do direito real e o segundo à modalidade de seu exercício" ${ }^{32}$.

À época da promulgação do Código Civil de 1916, indagou-se qual o regime adotado pelo legislador pátrio: numerus clausus (enumeração taxativa) ou numerus apertus (enumeração simplesmente exemplificativa).

\footnotetext{
${ }^{29}$ Cf. Menezes Cordeiro, Direitos Reais, p. 301/316.

${ }^{30} \mathrm{O}$ artigo 1.225 do Código Civil estabelece que são direitos reais: a propriedade, a superfície, as servidões, o usufruto, o uso, a habitação, o direito do promitente comprador do imóvel, o penhor, a hipoteca, a anticrese, a concessão de uso especial para fins de moradia e a concessão de direito real de uso. Vale advertir que a taxatividade não significa a proibição de criação, pelo legislador ordinário, de novas categorias de direitos reais, mas apenas que a vontade particular não é autônoma para a formação de novas figuras.

${ }^{31}$ Multipropriedade Imobiliária, p. 82.

${ }^{32}$ Em raciocínio semelhante, vale conferir Edmundo Gatti (Teoria General de Los Derechos Reales, p. 126127): assevera que os conceitos de numerus clausus e tipicidade dos direitos reais podem, conforme o sentido que se dê à tipicidade, identificar-se ou não.
} 
Prevaleceu a primeira posição ${ }^{33}$, mantida com o novo Código Civil.

A questão é tormentosa, também, no direito estrangeiro. O Código Civil Português, em seu artigo 1.306, foi o primeiro Código europeu a resolver expressamente o problema, destacando que "não é permitida a constituição, com carácter real, de restrições ao direito de propriedade ou de figuras parcelares desse direito senão nos casos previstos em lei”.

O sistema fechado também prepondera nos ordenamentos suíço, austríaco, sueco, holandês e argentino. Na França e na Espanha, ao revés, concluiu-se pela existência de um numerus apertus.

O numerus clausus se justifica pela oponibilidade erga omnes dos direitos reais. Com efeito, entende-se que não seria razoável admitir que a autonomia da vontade gerasse vínculos que atingissem situações jurídicas de terceiros ${ }^{34}$.

Nesse mesmo sentido, assevera A. Santos Justo ${ }^{35}$ que "impedindo a proliferação de direitos reais e a sua contitularidade, afasta embaraços à livre circulação de bens; permite a melhor exploração das coisas; evita atritos; e afasta a possibilidade de alguns agravarem a liberdade dos restantes membros da comunidade”.

\footnotetext{
${ }^{33}$ Explica o Darcy Bessone (Direitos Reais, p. 9) que Lafayette, Dídimo da Veiga e Pontes de Miranda, dentre outros, entendiam que a lista do artigo 674 do Código Civil de 1916 era taxativa. Outra corrente, sustentada por doutrinadores de renome como Afonso Fraga, Lacerda de Almeida e Carvalho Santos consideravam o rol exemplificativo. O debate é interessante e merece o registro: "O último grupo se vale do argumento de que, no projeto elaborado por Clóvis, estava expresso que somente se consideram direitos reais, além da propriedade, os arrolados por lei. O advérbio somente foi suprimido em conseqüência de emenda aprovada. De outra parte, acrescenta, podendo o domínio ser decomposto em tantos direitos quantas sejam as frações de utilidade econômica que da coisa se obtém, não é possível determinar-se, em um texto legal, o número desses direitos. Não se deve, por isso mesmo, restringir a aplicação do princípio da liberdade das convenções, nesse terreno. A esses argumentos, podem ser opostos outros, como o de que a supressão do advérbio somente visou apenas aprimorar a redação do texto, sem lhe comprometer o alcance, ou o de que, quando um direito é considerado real pela lei, todas as partes, em que ele se decomponha, serão também reais, por força da lei, já que a realidade do todo se comunica, necessariamente, às partes resultantes de seu fracionamento. Assim, o caráter real, nesses casos de decomposição do direito real, teria origem na lei, não na convenção. Por fim, deve-se ter em vista que, destinando-se o direito real a operar contra todos, não deve ter origem apenas na vontade das partes, recomendando-se, por isso mesmo, que tenha base legal”.

${ }^{34}$ Para Gustavo Tepedino (Op. cit., p. 84) "tal concepção, ainda hoje justificada, sobretudo pelo princípio da relatividade dos contratos, segundo o qual a autonomia privada não pode criar vínculos que atinjam situações de terceiros, veda a criação de direitos reais que, sendo dotados de eficácia erga omnes, criariam o dever genérico de abstenção, sem o prévio consenso da coletividade e sem a generalidade e abstração próprias da norma jurídica. Só a lei, no sistema democrático, revela o consenso social capaz de permitir a produção de efeitos erga omnes".

${ }^{35}$ Direitos Reais, p. 36.
} 
O tema, contudo, não é pacífico.

José de Oliveira Ascensão, embora aplauda o legislador português pela clareza na resolução do problema, considera que o fez na direção errada, por uma excessiva preocupação com a segurança. Para o ilustre professor da Faculdade de Direito de Lisboa, o sistema aberto seria preferível, pois atenderia muito mais às necessidades, adaptando-se a uma evolução que não deve ser dificultada ${ }^{36}$.

Em sua concepção, os inconvenientes apontados pelos autores que repudiam tal sistema poderiam ser prevenidos desde que traçados "cuidadosamente os limites de atuação da autonomia privada" e, também, que se exigisse "a publicidade de todo o direito real inominado".

Luciano de Camargo Penteado, que adota posição em favor do sistema fechado, retrata a mesma discussão do direito italiano ${ }^{37}$. Cita a posição de Maria Costanza, para quem os danos à coletividade de atos de autonomia privada na modelagem de novas categorias de direito real não necessitariam de outra regra de controle que a do interesse merecedor de tutela, prevista no artigo 1.322 do Código Civil italiano ${ }^{38}$.

Trata-se, sem dúvida, de um traço que distingue os direitos reais dos direitos pessoais. Nestes, ainda que existam figuras típicas, predomina a autonomia da vontade, de sorte que os particulares podem dispor dos seus interesses de forma bastante $\operatorname{ampla}^{39}$.

\footnotetext{
${ }^{36}$ Op. cit. p. 154.

${ }_{37}^{37}$ Para o autor (Op. cit. p. 93).

38 "Art. 1322 Autonomia contrattuale

Le parti possono liberamente determinare il contenuto del contratto nei limiti imposti dalla legge (e dalle norme corporative).

Le parti possono anche concludere contratti che non appartengono ai tipi aventi una disciplina particolare, purché siano diretti a realizzare interessi meritevoli di tutela secondo l'ordinamento giuridico."

${ }^{39}$ Estabelece o artigo 425 do Código Civil que é lícito às partes estipular contratos atípicos, observadas as regras gerais. Como observa Serpa Lopes (ob. cit., p. 32), no direito das obrigações, "ao lado das figuras típicas, legalmente reguladas (...) estende-se um imenso campo ao jurista, semeado das mais caprichosas formas contratuais - os contratos atípicos - conseqüência e criação das necessidades econômicas, dia a dia mais crescentes, formando o que se denominou a pululação dos contratos, dada a facilidade proporcionada pela autonomia da vontade, que, malgrado as limitações sofridas, ainda continua com larga margem para criar e desenvolver novos tipos de contrato".
} 
Todavia, mesmo reconhecendo a plena validade dos princípios da taxatividade e tipicidade, não se pode excluir a autonomia da vontade do âmbito dos direitos reais.

Decerto, ainda que necessária a previsão legal, existe um amplo campo para que as partes definam o conteúdo e a estrutura desses direitos ${ }^{40}$.

Gustavo Tepedino sustenta que há margem para a atuação da autonomia privada no âmbito de cada direito real $^{41}$. Partindo dessa constatação, conclui que a discussão quanto ao numerus clausus deve ser redimensionada, pois o estabelecimento de situações jurídicas com eficácia real, cuja origem é convencional, é uma realidade.

Assim, na opinião do renomado autor, é preciso que se estabeleça um controle de legitimidade sobre tais vínculos ${ }^{42}$.

\subsection{Outras características}

A aquisição dos direitos reais exige visibilidade (característica da publicidade). Em se tratando de bens imóveis, os direitos reais só se adquirem com o registro. Para os móveis, é necessária a tradição.

\footnotetext{
40 André Pinto da Rocha Osorio Gondinho, em interessante monografia sobre o tema da autonomia da vontade nos direitos reais (Direitos Reais e Autonomia da Vontade, p. 35), alcança igual conclusão: "Assim é que a autonomia da vontade, conquanto esteja proibida de constituir tipos exóticos de direitos reais, pode intervir na modelação dos direitos reais estatuídos em lei, sempre que isto seja permitido, quer seja mediante disposições genericamente permissivas (...), quer seja através do simples afloramento do princípio geral de que os direitos reais menores se regem pelos seus respectivos títulos. Na verdade, a tipologia dos direitos reais satisfaz-se com a descrição fundamental das situações jurídicas com essa natureza, mas não exclui que nelas se encontre ainda um conteúdo acessório, que pode ser obra das partes. A admissão, portanto, em nosso Direito, do princípio do numerus clausus não impede que se acatem modificações dos direitos reais por obra da autonomia da vontade. Com efeito, o tipo de direito real tem todo um conteúdo acessório, que é vastamente moldável pela atuação dos sujeitos de direito interessados, através da substituição de disposições supletivas”.

${ }^{41}$ Ob. cit., p. 83.

${ }^{42}$ Op. cit. p.85: "Reside aí, a rigor, o verdadeiro significado de que se reveste o princípio da tipicidade, capaz de evitar vínculos (e, de uma maneira geral, formas de aproveitamento de coisas) prejudiciais para os contratantes e para a coletividade. O controle de legalidade não pode limitar-se, por isso mesmo, ao princípio do numerus clausus (no sentido de impedir o surgimento de situações reais) e tampouco à legislação ordinária, devendo abranger a tutela constitucional da iniciativa privada e da propriedade, de maneira que a atividade econômica se submeta aos princípios constitucionais, fazendo incidir, nas relações privadas, no âmbito das quais se inserem as relações de multipropriedade, os valores existenciais e sociais situados no vértice do ordenamento."
} 
A oponibilidade erga omnes torna necessário que todos conheçam - ou possam conhecer - os titulares do direito real. Deste modo, o registro e a tradição funcionam como meio de publicidade da titularidade dos direitos reais.

Não existem dois direitos reais, de igual conteúdo, sobre a mesma coisa. Trata-se da característica da exclusividade ${ }^{43}$. O poder real e imediato sobre uma coisa exclui a existência de outro direito real idêntico sobre o mesmo objeto.

Admite-se, todavia, o desmembramento dos direitos reais (princípio da elasticidade). Como observa A. Santos Justo, o direito sobre uma coisa tende a abranger o máximo de utilidades que proporciona, de modo a estender-se para abranger as faculdades que abstratamente contém ${ }^{44}$.

É o caso, por exemplo, do usufrutuário, que exerce seus direitos sobre a coisa de modo independente aos direitos do nu-proprietário. E, quando o direito se extingue, retorna às mãos do proprietário, em função da característica elástica dos poderes.

\section{Classificação dos direitos reais:}

A doutrina apresenta diferentes classificações para os direitos reais. Predomina aquela que os ordena em direitos reais de gozo, de garantia e de aquisição ${ }^{45}$.

\subsection{Direitos reais de gozo}

Os direitos reais de gozo conferem ao seu titular o poder ou a faculdade de utilizar, total ou parcialmente, a coisa, e também de se apropriar dos seus frutos.

${ }^{43}$ O condomínio não contraria a ideia da exclusividade, pois cada condômino exerce seu direito sobre porções ideais, distintas e exclusivas.

${ }^{44}$ Op. cit., p. 29.

${ }^{45}$ Maria Helena Diniz adota a classificação de Serpa Lopes, seguindo o critério da extensão dos seus poderes atribuídos pelo direito real. Assim, a propriedade "seria o núcleo do sistema dos direitos reais devido estar caracterizada pelo direito de posse, uso, gozo e disposição. A posse aparece como exteriorização do domínio. Os demais direitos reais formam características conforme atinjam o jus disponendi, utendi ou fruendi" (Op. cit. 20). É a mesma classificação adotada por Washington de Barros Monteiro. Assim, de um lado se coloca a propriedade (direito sobre a própria coisa) e, de outro, os chamados direitos reais limitados ou direitos reais sobre coisa alheia. 
Estão relacionados à função econômica consagrada da trilogia "usar", "fruir" e "dispor". O conteúdo do direito pode ser mais ou menos amplo, pois compreende desde a propriedade até o direito real de habitação.

Destinam-se, em síntese, à satisfação de necessidades do titular, realçando a noção de utilidade que o bem proporciona ao sujeito.

Os direitos reais de gozo são divididos em direitos reais sobre coisa própria (jus in re propria) e direitos reais sobre coisa alheia (jus in re aliena).

Na primeira espécie encontra-se a propriedade ou domínio, o direito real por excelência ${ }^{46}$. Aqui, há uma submissão total da coisa em relação ao titular ${ }^{47}$, que detém a faculdade de usar, gozar e dispor da coisa, e o direito de reavê-la do poder de quem quer que injustamente a possua ou detenha.

Os direitos reais sobre coisa alheia são os direitos reais limitados, tais como a servidão, o usufruto e o uso. Proporcionam ao titular uma função de gozo e aproveitamento $^{48}$; sempre existirá, contudo, a figura do proprietário ${ }^{49}$.

O titular do domínio sofre uma restrição temporária nos seus poderes, vez que o terceiro gozará e usará a coisa que lhe pertence. A disponibilidade, entretanto, é exclusiva do proprietário.

\footnotetext{
${ }^{46}$ Para Luiz Edson Fachin (Direitos Reais, p.1), na introdução à obra de Orlando Gomes, da qual é atualizador, ressalta que "a propriedade está na base de sustentação de um dos pilares do sistema jurídico espelhado no Direito Civil tradicional; ao lado da posse e da empresa, propicia edificar uma espécie de estatuto jurídico sobre o patrimônio. Emerge daí o conjunto de direitos e deveres atinentes à titularidade de bens, coisas e interesses. Tal feixe de posições jurídicas, na radiografia das relações jurídicas de Direito Privado, se posiciona ao lado do contrato e da família. Juntos, propriedade, contrato e família compõem esse tríplice sustento das relações jurídicas".

${ }^{47}$ Evidente que a liberdade não é irrestrita e está limitada pela função social da propriedade.

${ }^{48}$ Maria Helena Diniz ( $\mathrm{Ob}$ cit., p. 360), com apoio nas lições de Goffredo Telles Jr., explica que "relativamente a coisas alheias uma pessoa tem direito real, se recebeu, por meio de norma jurídica, permissão do seu proprietário para usá-las ou tê-las, como se fossem suas, em determinadas circunstâncias, ou sob condição, de acordo com a lei e com o que foi estabelecido, em contrato válido. Os direitos reais referentes a coisas alheias são os citados direitos subjetivos concernentes a coisas incorpóreas, como os direitos do usufrutuário, do enfiteuta, do credor hipotecário, anticrético etc. (...) A propriedade é o direito real mais completo; seu titular detém o jus utendi, o jus fruendi e o jus abutendi ou disponendi, podendo reivindicar o bem de quem quer que injustamente o possua. De maneira que nada obsta que ele faça com que alguns dos seus poderes passem a pertencer ao patrimônio de outrem, que terá, então, direito real sobre coisa alheia".

${ }^{49}$ Esses direitos reais conferem aos titulares determinada fração dos poderes do titular.
} 


\subsection{Direitos reais de garantia}

Os direitos reais de garantia conferem ao credor o poder ou faculdade de receber o seu crédito com preferência sobre os demais credores do devedor.

Visam assegurar a satisfação de direitos de crédito, colocando os seus titulares numa posição preferencial em relação aos outros credores.

Conferem ao credor a pretensão de obter o pagamento de uma dívida com o valor do bem aplicado exclusivamente à sua satisfação ${ }^{50}$.

Como explica Luciano de Camargo Penteado, "os direitos reais com função de garantia situam-se no nível da responsabilidade da relação obrigacional, permitindo a adstrição da coisa à satisfação do crédito, na hipótese de não cumprimento espontâneo, conferindo, assim, uma maior força econômica e jurídica à pretensão de direito das obrigações" ${ }^{\text {"51. }}$.

Para Serpa Lopes, os direitos reais de garantia afetam o ius disponendi, pois, enquanto a dívida garantida não for paga, paralisa a função de transmissibilidade integral da coisa onerada, vinculando o adquirente na proporção do ônus real que a sobrecarregar $^{52}$.

\subsection{Direito real de aquisição}

O direito real de aquisição confere, ao seu titular, a faculdade de adquirir um direito real de gozo sobre a coisa.

\footnotetext{
${ }^{50}$ Os direitos reais com função de garantia têm como características principais a sequela, a excussão e a preferência.

${ }^{51}$ Ob. cit., p. 127. O autor propõe uma distinção entre os direitos reais de garantia e os direitos reais em garantia. Estes últimos, seriam direitos reais típicos empregados com função outra que a típica. É o caso da propriedade fiduciária, que não é um direito real novo, mas sim um direito real já conhecido, empregado com função diversa (dado em garantia).

${ }^{52}$ Op. cit. p. 39.
} 
É a promessa irretratável de venda e compra, contrato pelo qual o promitente vendedor obriga-se a vender ao compromissário comprador determinado imóvel, pelo preço, condições e modo convencionados, outorgando-lhe a escritura definitiva quando houver o adimplemento da obrigação.

O compromissário comprador adquire direito real sobre o imóvel, oponível erga omnes e desfruta da sequela. Pode, assim, reivindicar a coisa em poder de quem quer que a detenha ${ }^{53}$.

\section{Distinção entre direitos reais e direitos pessoais}

Tormentosa a distinção entre os direitos reais e os direitos pessoais, é forçoso reconhecer que inexiste um critério satisfatório para estabelecer essa diferenciação. Há, inclusive, aqueles que afastam a separação ${ }^{54}$.

São duas as teorias essenciais ao estudo da questão: a realista (clássica ou tradicional) e a personalista.

A primeira considera direito real o poder da pessoa sobre a coisa, em relação estabelecida de forma direta e sem intermediários. No exercício de uma faculdade real não se identifica relação com qualquer outro sujeito ${ }^{55}$.

Prevaleceu até o século XIX e remonta à Idade Média, mais precisamente aos glosadores, que a elaboraram com base no conceito romano de ação real (actio in rem).

\footnotetext{
${ }^{53}$ Para Serpa Lopes (Op. cit. p. 39), o direito real de aquisição se reflete igualmente sobre o ius disponendi, pois caso o devedor resolva alienar a coisa que prometeu vender, o comprador, ao adquiri-la, se subordina igualmente ao ônus real que sobre ela pesa, ou seja, a obrigação de outorgar a escritura definitiva.

${ }^{54}$ A doutrina monista afasta a dicotomia entre os direitos reais e pessoais. Como explica Miguel Maria de Serpa Lopes (ob. cit., p. 21), para tal corrente os direitos reais seriam dotados dos mesmos caracteres dos direitos das obrigações, de modo a não existir entre eles qualquer ponto de dessemelhança. Demogue sustenta que o problema está apenas na intensidade do direito. Haveria, assim, direitos mais fortes e mais fracos. $\mathrm{O}$ direito real seria mais forte do que o direito pessoal, pois reúne alguns atributos que lhe são próprios, como a sequela e a preferência.

55 A. Santos Justos (Op. cit., p. 45), com apoio em Orlando de Carvalho, destaca que a teoria clássica "corresponde à intuição mais ostensiva ou mais empírica do fenômeno: à sensação que a dominialidade imediatamente nos dá e que é da fruição, sem intermediários, de um objecto”.
} 
Para os seus adeptos, essa é a essência que diferencia os direitos reais dos direitos pessoais, que poderiam ser opostos unicamente a uma pessoa, de quem se exige um determinado comportamento.

Observa Darcy Bessone, ao abordar o ponto de vista da escola clássica, que o papel da pessoa é completamente diferente nos pessoais e reais: "no primeiro, o devedor, cumprindo a obrigação, presta colaboração, para a realização do direito, pois é através da prestação prometida que ele se efetiva. No direito real, a participação de outra pessoa, que não seja o titular do direito, terá o caráter de oposição, porque, sendo o direito real um poder jurídico e imediato sobre a coisa, somente interfere outra pessoa no quadro próprio dele para embaraçar-lhe o exercício, como ocorre, por exemplo, na usurpação de coisa alheia" 56.

Os personalistas se opõem à ideia de uma ligação entre o sujeito e a $\operatorname{coisa}^{57}$.

Defendem que todo direito pressupõe, necessariamente, uma relação entre pessoas. $\mathrm{O}$ poder direto e imediato sobre a coisa seria uma simples consequência jurídica de impor aos outros uma abstenção.

Ademais, a oponibilidade a terceiros não seria uma característica exclusiva dos direitos reais, mas presente em todos os direitos absolutos, tal como ocorre com os direitos da personalidade.

Conceituam o direito real como um poder atribuído ao titular para excluir as demais pessoas de qualquer ingerência na coisa que constitui o seu objeto, desde que incompatível com seu conteúdo.

\footnotetext{
${ }^{56}$ Ob. cit., p. 5.

${ }^{57}$ Destaca-se na crítica à teoria realista Bernard Windscheid, da escola Pandectística. Seu pensamento é sintetizado por Luciano de Camargo Penteado (Op. cit., p. 60): “haveria, em realidade, relação entre pessoas quando também se falasse de propriedade, mas esta relação teria por objeto a coisa e por sujeito passivo a coletividade concebida de modo indeterminado e potencial. Criou assim a categoria conceptual de um sujeito passivo universal. Este sujeito passivo, composto por todos os integrantes da comunidade em que se exerce propriedade, em virtude da relação jurídica, teria assim, em sua esfera jurídica patrimonial, um dever de abstenção. Deste modo, o poder de vontade que o proprietário exercesse sobre o mundo exterior corpóreo, sobre as coisas, seria correlato a um específico dever legal de respeito e não intromissão e teria por substância uma pretensão geral à exclusão”. A teoria personalista também é defendida por Thön, Roguin e Planiol.
} 
A coisa consistiria, na verdade, no objeto do direito, ao passo que o sujeito passivo seria a generalidade anônima dos indivíduos.

Em outra expressão, sujeito passivo universal ${ }^{58}$.

Assim, o direito protege-se com a obrigação passiva universal, mas não fica claro o que é e em que consiste esse direito. Além disso, a obrigação não tem conteúdo patrimonial, de sorte que não poderia ser a contrapartida de um direito real ${ }^{59}$.

\section{Caio Mário da Silva Pereira afirma que a teoria personalista tem} importância, do ponto de vista filosófico e moral, pois é de difícil aceitação a ideia de uma relação direta entre uma pessoa e uma coisa ${ }^{60}$.

\footnotetext{
${ }^{58}$ Neste ponto, vale mencionar a observação crítica de Oliveira Ascensão quando diz que "sobre todos os outros recai o dever genérico de se absterem de actividades que invadam a esfera reservada ao titular. $O$ dever genérico não está por natureza integrado numa relação. Mas note-se que desde que surja a possibilidade de violação por quaisquer meios - materiais ou jurídicos - dum determinado direito alheio, nasce um dever específico, a cargo do sujeito, de respeitar aquele bem juridicamente afecto a outrem. A inobservância desse dever constitui o violador em responsabilidade e origina uma verdadeira relação jurídica. (...) Este esquema, simples e aderente à realidade, permite obter os mesmos resultados práticos que a relação passiva universal, sem reproduzir os vícios teóricos desta” (Direito Civil. Reais, p. 608).

${ }^{59}$ Orlando Gomes (Direitos Reais, p. 14), com apoio em Marty et Raynaud, sintetiza as críticas à concepção personalista: “1 ${ }^{a}$ ) A obrigação passiva universal é fundamentalmente diferente da obrigação comum que liga um devedor a seu credor, pois esta é um elemento do passivo daquele; ora, ninguém pensaria em inscrever no passivo de seu patrimônio a obrigação de respeitar os direitos reais de outrem; na realidade, pois, a obrigação passiva universal não é uma obrigação no sentido estrito da palavra; é uma regra de conduta; $2^{a}$ ) a obrigação de respeitar os direitos de outrem não é especial dos direitos reais; existe para todos os direitos, mesmo os de crédito, assim como o demonstra, notadamente, a responsabilidade do terceiro, autor ou cúmplice da violação de uma obrigação contratual. Ademais, a aceitação da teoria personalista, em suas conseqüências últimas, conduziria à supressão da categoria de direitos reais, pois todos os direitos seriam pessoais, dado que ficariam reduzidos a vínculos obrigacionais". Também Darcy Bessone (Op. cit., p. 5) argumenta que não se concebe uma obrigação que não tenha conteúdo patrimonial. Assim, explica, Marcel Planiol e George Ripert retificaram sua teoria, de sorte que a concepção da obrigação passiva universal fosse substituída pela ideia do devedor indeterminado. Desse modo, existiria o dever geral de respeito ao direito real, mas a figura do devedor surgiria, determinadamente, quando se violasse tal obrigação, ofendendo-se o direito. Vale dizer, a indeterminação provisória do sujeito passivo desapareceria no momento em que se verificasse a lesão do direito.

${ }^{60}$ Op. cit., p. 3. "não obstante o desfavor que perante bons autores envolve a doutrina personalista, ela continua, do ponto de vista filosófico, a merecer aplausos. Sem dúvida que é muito mais simples e prático dizer que o direito real arma-se entre o sujeito e a coisa, através de assenhoramento ou dominação. Mas, do ponto de vista moral, não encontra explicação satisfatória esta relação entre pessoa e coisa. Todo direito se constitui entre humanos, pouco importando a indeterminação subjetiva, que, aliás, em numerosas ocorrências aparece, sem repulsa ou protesto. E no caso da pessoa jurídica, é necessária sua personificação hominum causa, a fim de que se revista da titularidade jurídica. A teoria realista seria então mais pragmática. Mas encarada a distinção em termos de pura ciência, a teoria personalista é mais exata”.
} 
Para Manuel Henrique Mesquita, a nota ou momento fundamental do fenômeno da realidade é a subordinação das coisas à soberania das pessoas. Nesse passo, observa, o dever geral de abstenção surge de modo reflexo, como um efeito da atribuição ou reconhecimento dessa soberania ${ }^{61}$.

$\mathrm{Na}$ opinião do autor, enquadrar o fenômeno com base em seus elementos ou categorias secundários acarretaria o desvirtuamento de sua essência. Assim, “o direito real proporciona ao respectivo titular uma esfera ou área reservada e afasta ou exclui dessa área, através do dever geral de abstenção, todas as demais pessoas”.

Manuel Henrique Mesquita aponta que a doutrina clássica limitava-se a definir o direito real como um poder direto e imediato sobre uma coisa, sem a preocupação de mencionar a matriz ou o fundamento jurídico desse poder.

Ocorre que nos direitos pessoais de gozo (a exemplo do comodato), também existe um poder direto e imediato sobre a coisa em favor do comodatário. O que distingue as situações é a relação de domínio ou soberania estabelecida entre o titular do direito e a coisa ${ }^{62}$.

Uma terceira corrente, chamada de eclética ou mista, busca conciliar as posições extremadas de clássicos e personalistas ${ }^{63}$. Seus defensores sustentam que os direitos reais ostentam duas faces: uma interna (ou instrumental), que se traduz no poder direto e imediato sobre a coisa; outra externa (essencial), que se identifica com a relação entre o titular desse direito e as demais pessoas.

\footnotetext{
${ }^{61}$ Op. cit., p.70 e ss. O autor entende que os direitos reais não são direitos contra as pessoas ou em relação às pessoas, mas sim direitos de soberania sobre as coisas.

${ }^{62}$ Nas palavras do autor (Op. cit., p. 73): "Esse fundamento é a relação de domínio ou soberania estabelecida entre o titular do direito e a coisa. O poder directo e imediato surge como conseqüência ou corolário desta relação, revestindo a natureza de um poder autônomo ou independente, isto é, de um poder que tem a sua fonte ou matriz na própria relação de soberania e que, por conseguinte, não pressupõe a cooperação de quem quer que seja, não depende de ninguém”. Um direito pessoal de gozo não se assenta numa relação de soberania, mas antes numa obrigação assumida por quem tem a legitimidade para dispor de gozo da coisa.

${ }^{63}$ A teoria surgiu na Alemanha com Bekker (apud A. Santos Justo, p. 48).
} 
Miguel Maria de Serpa Lopes, após abordar os principais elementos de cada uma dessas teorias, conclui que nenhuma delas é verdadeira por si mesma. Recorre à lição de Carvalho de Mendonça para estabelecer a distinção ${ }^{64}$.

Orlando Gomes explica que os autores modernos recorrem aos preceitos da teoria clássica, mas com enfoque na estrutura interna do direito real, destacando que o poder de utilização da coisa, sem intermediários, é a característica fundamental dos direitos reais ${ }^{65}$.

Estabelecidas as principais correntes, é possível resumir as diferenças apontadas pelos estudiosos. Pode-se destacar a dualidade que caracteriza os direitos pessoais (binômio credor e devedor), em contraposição à unicidade do direito real, que envolve apenas o sujeito ativo.

Outrossim, os direitos pessoais, quando violados, atribuem ao titular ação apenas contra quem figura na relação jurídica como sujeito passivo, ao passo que, nos direitos reais, ao titular é conferida ação real contra quem indistintamente detiver a coisa, em virtude da sequela.

O objeto do direito pessoal é uma prestação do devedor, que pode ser genérica, desde que determinável; já os direitos reais têm como objeto coisas corpóreas e sempre determinadas.

\footnotetext{
${ }^{64}$ Diz o autor (Op. cit., p. 26) que "não se pode ser exclusivamente monista ou propender unicamente pela solução dos exegetas; não se pode criticar a proposição dêstes em proveito da idéia exclusiva de obrigação passiva universal. A realidade das coisas impõe a utilização de ambas as proposições para se poder bem caracterizar o direito real (...)"o direito real é um poder que a sociedade reconhece no titular sobre uma coisa do mundo externo; o direito de crédito é o mesmo poder que a sociedade reconhece no indivíduo para limitar momentaneamente a liberdade de outrem e exigir-lhe um fato, uma prestação. Os elementos das duas séries, portanto, são: a) o titular do direito, ou o poder reconhecido; b) o poder que o titular tem sôbre a coisa (direito real) ou sôbre a pessoa (direito obrigacional), por cujo motivo existe o direito. Mas nunca a pessoa do devedor no direito de crédito, nem a coisa no direito real constitui o objeto do direito".

${ }^{65} \mathrm{O}$ autor (Op. cit., p. 15) cita De Page para esclarecer a ideia: "a característica do direito real será sempre o fato de se exercer diretamente, sem interposição de quem quer que seja, enquanto o direito pessoal supõe necessariamente a intervenção de outro sujeito de direito. Assim, o proprietário, titular máximo de um direito real, o exerce, utilizando a coisa sem ser preciso qualquer intermediário. Sua ação é direta e imediata. Já o comodatário, para que possa usar a coisa emprestada, necessita da intervenção do comodante; precisa que, mediante o contrato de comodato, o proprietário da coisa, nele figurando como comodante, lha entregue, assegurando-lhe o direito de usá-la com a obrigação de restitui-la após o decurso de certo tempo".
} 
O direito de crédito tem natureza transitória. O direito real, ao contrário, tende à perpetuidade.

As normas que regulam os direitos reais têm natureza cogente, de ordem pública; as que disciplinam o direito obrigacional, por sua vez, são, em regra, dispositivas ou facultativas, permitindo às partes o livre exercício da autonomia da vontade.

É bem verdade que a clássica distinção dos direitos subjetivos vem sofrendo revisão pela doutrina.

Isso porque há certas relações reais, como ocorre nos direitos de fruição, que não podem ser estendidas à coletividade, mas apenas aos titulares de determinadas relações subjetivas. É o caso, por exemplo, do proprietário do prédio serviente.

De outra parte, o respeito aos direitos subjetivos alheios não é uma característica exclusiva dos direitos reais.

Assim, nos direitos de crédito também existe uma espécie de sujeição universal; com efeito, terceiros devem respeitar os contratos firmados, sob pena de incorrerem em responsabilização civil. A ideia está relacionada com os princípios da função social e da boa-fé dos contratos.

Roberta Mauro e Silva faz uma extensa análise dos critérios usualmente utilizados pela doutrina para diferenciar os direitos reais dos obrigacionais e sustenta que muitos dos argumentos que sustentaram a dicotomia não mais subsistem. Deste modo, conclui, "talvez não seja absurdo sustentar a formulação de um direito comum às situações patrimoniais, que seria a síntese da disciplina de todas as relações de caráter patrimonial” 66 .

\footnotetext{
${ }^{66}$ Relações Reais e Relações Obrigacionais, p. 69. Pietro Perlingieri (Perfis do Direito Civil, p. 204), festejado autor italiano, apresenta conclusão semelhante: "portanto, as situações jurídicas reais não se reduzem ao exclusivo dever genérico de abstenção por parte de terceiros; elas, especialmente aquelas limitadas de gozo, caracterizam-se pela presença de obrigações específicas integrativas. Não existe, portanto, uma precisa separação entre situações creditórias e reais; frequentemente situações obrigacionais integram-se com interesses mais amplos e constituem situações complexas".
} 


\section{CAPÍTULO I: OBRIGAÇÕES PROPTER REM}

\section{Conceito de obrigações reais}

Como visto em capítulo próprio, predomina o entendimento de que a nota caracterizadora do direito real é o seu exercício pelo titular, de um modo autônomo, isto é, sem a intermediação de qualquer outro sujeito. A coisa é colocada à disposição ou à ordem do titular respectivo.

Nas palavras de Manuel Henrique Mesquita "é como se o legislador dissesse ao titular do direito: esta coisa pertence-te (direito de propriedade) ou está parcialmente afectada ao teu domínio (direitos reais limitados), segundo as regras por mim estabelecidas" 67.

Essas regras - poderes e limites impostos ao titular - constituem aquilo que o doutrinador português denomina de estatuto do direito real.

Ocorre que, com freqüência, o direito real impõe deveres ao seu titular. Assim, na esteira do renomado doutrinador português, as obrigações propter rem seriam justamente os "vínculos jurídicos por virtude dos quais uma pessoa, na qualidade de titular de um direito real, fica adstrita a outra (titular ou não, por sua vez, de um ius in re) à realização de uma prestação de dare ou de facere" ${ }^{\text {.68 }}$.

Em linha semelhante de raciocínio, Luís A. Carvalho Fernandes explica que, na análise da situação jurídica que decorre da titularidade de um direito real, há limitações ao exercício das faculdades que integram o seu conteúdo ${ }^{69}$.

Essas restrições, que têm origem em motivos de naturezas distintas (interesses públicos ou particulares), podem consistir na abstenção de certas condutas; em outros casos implicam na adoção de certos comportamentos: são as obrigações reais.

\footnotetext{
${ }^{67}$ Obrigações reais e ônus reais, p. 100.

${ }^{68}$ Idem. Vale observar que o autor ele restringe o conceito de obrigações reais àquelas que têm como objeto uma prestação de conteúdo positivo.

${ }^{69}$ Lições de direitos reais, p. 179.
} 
Em suma, infere-se que, em diversas hipóteses, o direito real impõe ao seu titular a satisfação de uma obrigação.

Como explica Antunes Varela, o caráter real das obrigações propter rem reside justamente na sua vinculação à coisa $^{70}$; vale dizer, o sujeito passivo será sempre aquele que for o titular da situação jurídica de direito real $^{71}$ e a prestação é imposta precisamente por causa dessa titularidade.

As obrigações reais são, portanto, situações nas quais o sujeito passivo é determinado, mediatamente, pela titularidade de uma situação jurídica de direito real ${ }^{72}$.

A definição de Giovanni Balbi é mais complexa e compreende aspectos que, na opinião deste autor, caracterizam a obrigação propter rem. Fala, desse modo, em obrigação real nos casos em que o devedor é titular de um direito real de gozo, de tal sorte que, extinto ou transmitido o direito real, se extingue ou se transmite a qualidade de devedor ${ }^{73}$.

A doutrina nacional acompanha a conceituação da obrigação propter rem como a situação pela qual o devedor é determinado em razão da titularidade de um direito real.

Confira-se, por todos, Serpa Lopes, para quem as obrigações reais podem ser definidas como "obrigações cuja força vinculante se manifesta, tendo em vista a situação do devedor em face de uma determinada coisa, isto é, quem a ela se vincula o faz em razão de sua situação jurídica de titular do domínio ou de uma relação possessória sobre uma determinada coisa, que é a base desse débito" 74 .

\footnotetext{
${ }^{70}$ Direito das obrigações, p. 45.

${ }^{71}$ É importante observar que, como adverte Eduardo A. Zannoni (Elementos de la obligación, p. 41), a relação entre a coisa e a obrigação não se traduz, necessariamente, na titularidade de um direito real. Decerto, há obrigações propter rem que decorrem da simples posse. Esse aspecto é muito importante e pouco explorado pelos tratadistas. Daí porque é mais correto utilizar a expressão situação do direito das coisas, que engloba a posse.

${ }^{72}$ Cf. Oliveira Ascensão, Direito civil - reais, p. 234.

${ }^{73}$ Le obbligazioni propter rem, p. 117.

${ }^{74}$ Curso de direito civil - direito das coisas, p. 50.
} 


\section{Dos fundamentos das obrigações propter rem}

A partir do século XX, foi acentuado o caráter social da propriedade. Decerto, a ideia de um direito pleno e absoluto do indivíduo sobre o bem se esvai, e a propriedade passa a ser compreendida como uma complexa situação jurídica subjetiva, ativa e passiva.

O enfoque, destarte, não é exclusivamente voltado aos interesses individuais do seu titular; a propriedade ostenta uma função social.

Para Orlando Gomes ${ }^{75}$, com supedâneo em Rodotá, a partir do momento em que o ordenamento jurídico reconheceu que o exercício dos poderes do proprietário não devia ser garantido apenas para a satisfação dos seus interesses, a função da propriedade tornou-se social.

A Constituição Federal de 1988, na esteira das Constituições democráticas ocidentais, assegura o direito de propriedade, o qual deverá atender a sua função social ${ }^{76}$. O Código Civil de 2002 contém disposição semelhante ${ }^{77}$.

A propriedade, portanto, apresenta um lado passivo e impõe ao proprietário um conjunto de deveres.

Na feliz expressão da Constituição da República Federal da Alemanha de 1949, a propriedade obriga ${ }^{78}$.

\footnotetext{
${ }^{75}$ Ob. cit., p. 125. Esclarece que a nova visão se manifesta em três aspectos: a) privação de certas faculdades; b) criação de um complexo de condição para que o proprietário possa exercer os seus poderes e c) a obrigação de exercer certos direitos elementares do domínio.

${ }^{76}$ Artigo $5^{\circ}$, XXII e XXIII. A Constituição Federal também estabelece, em seu artigo 170, que o direito de propriedade e a sua função social são princípios da ordem econômica. Para Fredie Didier Jr. (Op. cit., p. 94), esses princípios, numa análise apressada, "poderiam ser entendidos como antitéticos, na verdade se complementam, sendo a função social, atualmente, vista como parte integrante do próprio conteúdo da propriedade, seu outro lado - só há direito de propriedade se este for exercido de acordo com a sua função social".

77 “Art. 1.228. Parágrafo primeiro - O direito de propriedade deve ser exercido em consonância com as suas finalidades econômicas e sociais e de modo que sejam preservados, de conformidade com o estabelecido em lei especial, a flora, a fauna, as belezas naturais, o equilíbrio ecológico e o patrimônio histórico e artístico, bem como evitada a poluição do ar e das águas.
} 
Como assenta Pietro Perlingieri ${ }^{79}$, a função social não diz respeito apenas aos limites da propriedade; sustenta que, num sistema inspirado na solidariedade política, econômica e social, o conteúdo do princípio assume um papel de tipo promocional, de maneira que a disciplina das formas de propriedade e de suas interpretações deve ser dirigida para garantir e promover os valores sobre os quais se funda o ordenamento.

A doutrina da função social da propriedade auxilia a correta apreensão do significado e do fundamento das obrigações propter rem. Com efeito, o direito real não contempla apenas faculdades e benefícios aos seus titulares; ao contrário, também compreende restrições e pode implicar, até mesmo, em obrigações de conteúdo positivo ${ }^{80}$.

A esse respeito, depreende-se que, não obstante a heterogeneidade das hipóteses que podem ser consideradas como obrigações reais, todas estão relacionadas a um interesse, protegido por lei, o qual deverá ser respeitado pelo titular do direito real.

Assim ocorre, por exemplo, no dever imposto ao condômino de contribuir para as despesas do condomínio, na proporção da sua fração ideal. Essa obrigação, cuja natureza é propter rem, tem como fundamento justamente garantir o adequado funcionamento do condomínio.

Nesse passo, pode-se considerar que a obrigação real está relacionada ao conteúdo passivo do direito real que, pelos fundamentos expostos, não traduz apenas vantagens aos seus titulares.

\footnotetext{
${ }^{78}$ Nas palavras de Fredie Didier Jr. (A função social da propriedade e a tutela processual da posse, p. 96): "Se a propriedade não se apresenta, concretamente, como uma garantia da liberdade humana, servindo como instrumento de exercício de poder sobre outrem, seria rematado absurdo que se lhe reconhecesse o estatuto de direito humano; é preciso, enfim, reconhecer a propriedade-dever, o lado passivo de direitos humanos alheios. E aqui surge a concepção da função social da propriedade - outro princípio constitucional que rege a atividade econômica - e que aparece como complemento do estatuto constitucional da propriedade privada, impondo a ela um conjunto de deveres, ao lado dos clássicos poderes antes mencionados. Esse princípio (cláusula geral que rege a atividade econômica) serve como forma de balizamento constitucional do direito fundamental de propriedade, delimitando o seu conteúdo. Estabelece que a propriedade obriga ao proprietário. Além de poder jurídico, a propriedade traz consigo o dever de exercer este direito de modo a atingir determinadas finalidades; deixava a propriedade, pois, de ser um direito absoluto, cuja utilização deveria atender unicamente aos interesses do proprietário, na forma da concepção liberal que então prevalecia”.

${ }^{79}$ Perfis do direito civil, p. 226.

${ }^{80}$ Convém ressaltar, entretanto, que o interesse do credor de uma obrigação real não é, necessariamente, um interesse da coletividade. Ao contrário, no mais das vezes, o sujeito também é titular de um direito concorrente. Todavia, a função social é útil no sentido da limitação da noção da propriedade.
} 


\section{Breves considerações acerca da origem histórica das obrigações reais}

Os autores não costumam tratar dos registros históricos das obrigações reais, de sorte que o material a respeito do tema é escasso. Dentre aqueles que enfrentam a questão há uma considerável divergência, mais precisamente no que se refere à origem romana do instituto.

Paulo Carneiro Maia ${ }^{81}$ recorre a Cogliolo para sustentar que a distinção entre os direitos reais e obrigacionais foi uma conquista da sabedoria romana e um dos momentos fulgurantes da história de sua cultura.

Explica que os romanos estabeleciam uma estrita conexão entre o processo e o direito privado, de tal sorte que a forma de sanção correspondia à própria natureza dos respectivos direitos.

Havia a separação entre as actiones in personam (exercidas contra pessoas determinadas) e as actiones in rem (exercidas contra todos) baseada justamente na diferenciação entre os direitos pessoais e reais.

Uma terceira categoria de ação, chamada actio in rem scriptae, não decorria de um direito real; sua fórmula, entretanto, não indicava a pessoa do réu e, por isso, poderia ser intentada contra quem quer que fosse ${ }^{82}$.

Como exemplo desta espécie de ação, destaca a actio quod metus causa, proposta em face do autor de um ato violento ou, ainda, do possuidor da coisa obtida por meio da violência.

Conclui, portanto, que "no direito romano deparamos antecedentes irrecusáveis da obrigação propter rem. Existiam nêle inescondíveis relações jurídicas de caráter misto, como a qualificam Polacco, Venzi, De Ruggiero e outros mais, tuteladas pela 'actio in rem scriptae' de que emergiram”.

${ }^{81}$ Obrigação propter rem, p. 456.

${ }^{82}$ Paulo Carneiro Maia cita a obra de Alfredo Buzaid, para quem o direito romano conheceu diversas obrigações propter rem, a exemplo da 'servitus oneris ferendi', mediante a qual o proprietário do prédio serviente é obrigado a um facere, isto é, a reparar a parede ou a coluna sobre a qual se apóia o edifício alheio. 
Antunes Varela acompanha tal posição e ressalta que os jurisconsultos romanos já conheciam as obrigações propter rem $^{83}$.

Há, contudo, doutrinadores que consideram que a obrigação propter rem tem sua origem na Idade Média e não guarda qualquer relação com o direito romano.

Nesse sentido, Serpa Lopes, com apoio na lição de Rigaud, sustenta que a obrigação propter rem era totalmente desconhecida dos glosadores e ignorada no direito romano $^{84}$.

Seria, em realidade, um produto da obra dos canonistas, que a caracterizaram como uma espécie singular de obrigação, vinculada a um direito real. Para o autor, a origem seria um benefício que correspondia a todo ofício eclesiástico, consistente em conjunto de bens destinado à manutenção do titular.

A complexa forma de transmissão desse direito desenvolveu a ideia de obrigação propter rem.

\section{Os sujeitos da obrigação real}

Para Roxana B. Cánfora, os sujeitos das obrigações reais são, inicialmente, indeterminados, mas determináveis no surgimento da obrigação. Afirma que são os titulares dos direitos reais que extremam os polos da relação ${ }^{85}$.

\footnotetext{
${ }^{83}$ Direitos das obrigações, p. 65. Nesse mesmo sentido, observa Edgardo Valera (Obligaciones propter rem, p. 135) que as obrigações reais, aparentemente, foram conhecidas em Roma e na Idade Média, porém com contornos distintos. Cita Luis Alberto Peña Guzmán (Derecho Civil. Derechos Reales. Ed. TEA, Buenos Aires, 1973, Tomo I, n 23, I, p. 41), segundo o qual: “Los intérpretes del Derecho Romano dieron a dicho tipo de obligación de propter rem, en razón de que no era posible señalar de antemano quién era el deudor, pues tal carácter revistiría aquel que se encontrare en podeer de la cosa objeto de la obligación en el momento de trabarse la litis contestatio, lo que da lugar a la creación de un acción especial, la actio in rem scripta que permitía dirigirse contra personas distintas del deudor de la obligación".

${ }^{84}$ Observa, ainda, que o Código de Napoleão não tratou das obrigações reais, ainda que tenha sido objeto de estudos, desde os primeiros comentadores. Já o Código Civil Argentino, fiel à orientação de Teixeira de Freitas, estabeleceu expressamente que não existem obrigações que correspondam a direitos reais.

${ }^{85}$ Obligaciones reales, p. 8.
} 
Hassen Aberkane é autor de festejada obra sobre as obrigações propter $\mathrm{rem}^{86}$. Segundo o doutrinador, a utilidade dessa espécie de obrigação é resolver conflitos de interesses entre dois direitos rivais, estabelecendo um modo de convivência entre eles. Argumenta que credor e devedor são titulares de direito real, que pode recair sobre a mesma coisa ou sobre coisas diversas.

Ocorre que esses direitos podem se contrapor (direitos rivais), de modo que a obrigação propter rem tem como função resolver esse conflito, instituindo entre eles um modus vivendi aceitável, que possa assegurar sua existência pacífica e permitir o seu exercício concorrente.

Na concepção do respeitado autor francês, o direito real impõe a terceiros uma obrigação passiva universal, mais precisamente a de não perturbar o exercício do direito real por parte do seu titular.

Todavia, há alguns terceiros que estão em posição especial ao titular do direito real. A lei, para tornar possível o exercício do direito real, cria uma obrigação positiva.

Para Hassen Aberkane, portanto, a obrigação propter rem tem natureza idêntica à obrigação passiva universal, com a modificação derivada do fato de que ela se destina a resolver a situação especial de um terceiro que é titular de um direito antagônico ao direito do autor.

Manuel Henrique Mesquita, embora reconheça que as obrigações propter rem surjam fundamentalmente para solucionar conflitos de direitos reais ou entre cotitulares de direitos reais, assevera que tal situação não é um traço necessário ao instituto ${ }^{87}$.

\footnotetext{
${ }^{86}$ Essai d'une théorie générale de l'obligation "propter rem" en detroit positif français, p 23 e seguintes.

87 Obrigações reais e ônus reais, p. 272. Decerto, como ressalta o autor, na maior parte dos casos as obrigações propter rem são impostas ao titular de um direito real em beneficio do titular de outro direito da mesma natureza. É o que ocorre nas hipóteses de direitos de vizinhança e nos condomínios. Todavia, há outras hipóteses em que o credor não é titular de direito real. Menciona, como exemplo, o direito de preferência nos contratos de locação, que impõe ao locador (titular de um direito real) a obrigação de comunicar ao locatário a existência de proposta sobre o bem, dando-lhe preferência, em igualdade de condições com terceiros. O locatário, sujeito ativo da obrigação propter rem, ao contrário do que usualmente ocorre, não é titular de um direito real. Um outro exemplo, utilizado por José de Oliveira Ascensão (Direito Civil - Reais, p. 235), é o doador que reserva para si certos direitos sobre os bens doados.
} 
Igual é o posicionamento de Luís A. Carvalho Fernandes. Conquanto admita que, na maior parte dos casos, o credor de uma obrigação real também é titular de um direito real (o autor utiliza a expressão crédito $o b$ rem), sustenta que há casos em que o credor não é determinado pela titularidade de um direito real ${ }^{88}$.

Germán de Castro Vítores argumenta que a posição de Aberkane não pode ser considerada em seu sentido estrito e que é recomendável a análise casuística de cada relação ${ }^{89}$.

Não raro, afirma o autor, o implicado na relação pode ser um possuidor ou mesmo o titular de um direito pessoal.

José de Oliveira Ascensão distingue as situações jurídicas propter rem em sentido estrito, nas quais apenas um dos sujeitos é determinado mediatamente pela titularidade de um direito real, das relações jurídicas propter rem, as quais compreendem titulares de direitos reais em ambas as posições da obrigação ${ }^{90}$.

\section{A terminologia empregada}

São diversas as denominações utilizadas na referência ao instituto objeto desta dissertação. Predominam as expressões obrigação propter rem - cuja tradução seria “em razão da coisa” - e obrigação real.

Para ilustrar a variedade de designações, pode-se mencionar obrigação in rem, in rem scriptae, intra rem, obrigação rem, rei coherens, quod rem, obrigação puramente real, semi-real, ambulatória, inerente à posse, em razão da coisa, dentre outras.

\footnotetext{
${ }^{88}$ Lições de direitos reais, p. 181. Sustenta o autor: "Essa correspondência entre a obrigação real e o crédito real, hoc sensu, não é, porém, necessária. Vale isto por dizer que o titular do crédito que constitui o lado activo de uma obrigação real pode não ser determinado em função da titularidade de um direito real, mas por outra via. Um corolário desta mesma atuação é o campo de aplicação das obrigações reais não se circunscrever às relações de vizinhança, nem a casos de concurso de direitos reais sobre a mesma coisa, embora elas tenham aqui sua sede por excelência. Deste modo, se em benefício de certa pessoa, e sem qualquer ligação com um direito real, for imposta ao seu titular, e em conexão com o seu direito, uma obrigação de conteúdo positivo, não se vê razão definitiva para não a configurar como tal”.

${ }^{89}$ La obligación real en el derecho de bienes, p. 502.

${ }^{90}$ Op. cit., pág. 236.
} 
Edmundo Gatti observa que a pluralidade de nomes é um indício da falta de uniformidade de ideias e de conceitos sobre o assunto ${ }^{91}$.

O termo obrigação real, assevera Manuel Henrique Mesquita, está consagrado na doutrina ${ }^{92}$. O autor português considera que a expressão não se constitui em figura híbrida, mas apenas designa aquelas obrigações que têm origem no estatuto de um direito real. Assim, prossegue, o substantivo (obrigação) designa a natureza da figura, ao passo que o adjetivo (real) indica a sua matriz.

Luciano de Camargo Penteado sugere, com coerência, que a terminologia adequada consistiria em dever jurídico de causa real, pois a obrigação encontra sua origem e seu fundamento na titularidade de uma situação jurídica do direito das coisas ${ }^{93}$.

Carlos Roberto Gonçalves destaca que os direitos reais representam um direito sobre a coisa (ius in re), ao passo que as obrigações reais são concebidas como direitos advindos da coisa (ius ad rem) ${ }^{94}$.

\section{A natureza jurídica da obrigação propter rem}

É controvertida a natureza jurídica das obrigações reais ${ }^{95}$. São, fundamentalmente, três as posições que divergem sobre o tema.

\footnotetext{
${ }^{91}$ Derechos reales - teoría general, p. 113.

92 Obrigações Reais e Ónus Reais, p. 27.

93 Direito das coisas, p. 116. É interessante o raciocínio desenvolvido pelo autor: "Sugere-se, aqui, a terminologia de dever jurídico de causa real, ou dever jurídico com causa real, justamente para evidenciar que a gama de realidades ora estudada têm a natureza e a estrutura de uma relação jurídica obrigacional como as demais, particularizando-se, entretanto, pela sua causa aquisitiva, pelo factum antecedens que desencadeia o vínculo, qual seja, a situação jurídica de direito das coisas. Ao invés de ser voluntário, como nos contratos, legal, como na responsabilidade delitual, um desequilíbrio patrimonial, como no enriquecimento injustificado, a causa remota das obrigações propter rem é, apenas e tão somente, a titularidade jurídica de direito das coisas".

${ }^{94}$ Direito civil brasileiro, V Vol., p. 21.

95 O problema é bem colocado por Arnaldo Rizzardo (Direito das coisas: Lei $\mathrm{n}^{\circ}$ 10.406, de 10.01.2002, p. 13): "a natureza de tal obrigação envolve aspectos dos direitos reais e aspectos dos direitos pessoais. Como se observou, há uma obrigação pessoal, dirigida a satisfazer um direito derivado do próprio bem. Este misto de direito real e pessoal resulta do enlace do dever atribuído ao titular do domínio com a prestação que a própria coisa oferece ao terceiro. Todavia, há os que lhe dão o caráter de pessoalidade, em face de ser a relação jurídica uma prestação pessoal. Outra corrente inclina-se pelo aspecto da realidade que resulta o fato de ser alguém o titular de um direito real”.
} 
Para os personalistas, como explica Orlando Gomes, o simples fato de que a obrigação propter rem tem sua origem numa relação jurídica real não lhe retira a natureza predominantemente pessoal. Com o seu surgimento, argumenta, estabelece-se um vínculo jurídico entre dois sujeitos, cujo objeto é uma prestação, tal como ocorre com qualquer outra obrigação ${ }^{96}$.

Antonio Junqueira de Azevedo afirma que a obrigação real é uma obrigação lato sensu. Desse modo, consiste em direito pessoal, ainda que tipologicamente próximo aos direitos reais ${ }^{97}$.

Antunes Varela observa que, estruturalmente, as obrigações reais consistem em verdadeira relação de crédito; todavia, funcionalmente estão ligadas à coisa, de sorte que a substituição do obrigado afasta-se dos moldes comuns da transmissão das obrigações $^{98}$.

Edmundo Gatti corrobora o entendimento daqueles que defendem que a obrigação propter rem tem caráter essencialmente pessoal. Para o autor, são obrigações que ostentam características especiais no que se refere ao nascimento, transmissão e extinção ${ }^{99}$.

Os realistas, por sua vez, afirmam que a obrigação propter rem integra o próprio conteúdo do direito real, do qual não podem ser afastadas. Emprestam, assim, maior importância à sua vinculação à coisa, isto é, ao fato de que será sempre o devedor quem estiver na condição de titular do direito real sobre a coisa.

Edgardo Valera ressalta que a identificação entre as obrigações propter rem e os direitos reais tem grande aceitação entre os alemães ${ }^{100}$.

\footnotetext{
${ }^{96}$ Direitos reais, p. 25.

${ }^{97}$ Restrições convencionais de loteamento, pág. 314.

98 Op. cit., p. 46. Nas palavras do autor: "as obrigações comuns transmitem-se por meio de atos jurídicos (cessão de créditos, sub-rogação, assunção de dívida, endosso, sucessão por morte) que atingem diretamente a relação creditória. Na obrigação real, a substituição do titular passivo opera-se por via indireta, com a aquisição do direito sobre a coisa a que o dever de prestar se encontra ligado (...) Este modo especial de substituição (ou sucessão lato sensu) só vigora, no entanto, enquanto a obrigação real, continuando ligada a determinada coisa, se não autonomiza".

${ }^{99}$ Op. cit. p. 116.

${ }^{100}$ Obligaciones propter rem, p. 134.
} 
Outros, por fim, defendem a criação de uma terceira categoria, de caráter misto.

Nesse sentido, San Tiago Dantas, em magnífica obra sobre os Direitos de Vizinhança, afirma que as obrigações propter rem devem ser entendidas como "uma transição entre os dois extremos do direito real e do direito pessoal, com o fim de qualificar certas figuras ambíguas que tinham tanto de um como de outro" ${ }^{101}$.

Com efeito, para o renomado autor, o instituto consistiria em artifício técnico para explicar situações que não se enquadram nas categorias de direito real e de direito pessoal.

Serpa Lopes compartilha esse entendimento e afirma que o conceito de obrigação real configura uma espécie autônoma ${ }^{102}$.

Manuel Henrique Mesquita rechaça a classificação das obrigações propter rem em categoria mista ${ }^{103}$. Para o autor, não existe uma separação absoluta entre o conceito de obrigação e de direito real, não se justificando, portanto, a classificação.

A tendência dos autores é considerar as obrigações reais como espécie autônoma, situando-as em grupo intermediário entre direito real e direito pessoal.

\footnotetext{
${ }^{101} \mathrm{O}$ conflito de vizinhança e sua composição, p. 244.

102 Segundo o autor (Curso de direito civil - direito das coisas, p. 57): "deve tender a configurar-se como uma espécie autônoma, situada entre o direito real e o direito pessoal, por se destacar com essa peculiaridade: tornar-se dela devedor, quem quer que, em determinadas circunstâncias, se encontre em relação de domínio ou de posse sobre alguma coisa". Também Paulo Carneiro Maia (Op. cit., p. 459): "aquelas relações (obrigações propter rem) em que o direito real fica desvirtuado pela obrigação de fazer, que com êle segue junto, e o direito obrigacional sofre deformação pela faculdade dada ao credor de agir erga omnes relativamente à coisa gravada mediante ação real, não comportam enquadramento singular. Participam tanto dos direitos reais como dos direitos obrigacionais formando, por isto, os denominados direitos mistos, segundo opinião de abalizados autores". Para Carlos Roberto Gonçalves (Op. cit., p. 22) a obrigação propter rem constitui um tertium genus, por revelar a existência de direitos que não são puramente reais nem essencialmente obrigacionais.

103 Op. cit., p. 102-103: "Estruturalmente, é de verdadeiras obrigações que se trata, ou seja, de vínculos jurídicos por virtude dos quais uma pessoa, na qualidade de titular de um direito real, fica adstrita a realizar uma prestação em benefício de outra. Sucede apenas que estas obrigações se encontram exertadas, incluídas ou incrustadas no conteúdo de um ius in re, de cujo estatuto promanam".
} 
É inegável que as obrigações propter rem apresentam características que a identificam com o direito obrigacional, pois o seu conteúdo é precisamente uma prestação.

Não se pode olvidar, contudo, de um componente real, evidenciado na vinculação do proprietário ou possuidor da coisa como o sujeito passivo da obrigação propter rem. Essa característica as afastarias do regime comum das obrigações.

De todo modo, considerando a fragilidade da distinção existente entre os direitos reais e as obrigações, consideramos que a controvérsia acerca da natureza jurídica das obrigações propter rem tem sua importância diminuída.

\section{O conteúdo das obrigações reais}

Manuel Henrique Mesquita considera que somente as obrigações de conteúdo positivo devem ser qualificadas como propter rem; exclui do conceito as hipóteses em que ao titular do direito real sejam impostos comportamentos de abstenção, ainda que em favor de outros sujeitos ${ }^{104}$.

Nestes casos, afirma, a lei não cria relações intersubjetivas, mas apenas traça os contornos da esfera de domínio ou da soberania do titular sobre a coisa. Como assevera Luís A. Carvalho Fernandes, os deveres de conteúdo negativo são explicáveis à luz da noção de direito real, de sorte que a utilização da noção de obrigação propter rem seria um falso problema, uma inútil complicação conceitual ${ }^{105}$.

\footnotetext{
${ }^{104}$ Op. cit., p. 266. Sustenta o autor: "Quando a lei, por exemplo, proíbe que, a menos de certa distancia da linha divisória de um prédio, se abram vistas que excedam as medidas das chamadas aberturas de tolerância ou se plantem determinadas arvores, não estamos, ao invés do que amiúde se entende, perante obrigações propter rem. $O$ objectivo ou o sentido de tais proibições é apenas o de delimitar o conteúdo do direito de propriedade. Vedando ao proprietário a prática de certos actos, a lei não está a envolvê-lo em relações intersubjectivas (não está a criar obrigações em sentido técnico): está, pura e simplesmente, a fixar os limites até onde pode ir sua actuação, a traçar os contornos da sua esfera de domínio ou soberania”. ${ }^{105}$ Op. cit., p. 181.
} 
Luciano de Camargo Penteado segue a mesma orientação e observa que, quando há uma determinação legal de abstenção, não é necessário recorrer ao conceito de obrigações propter rem; são apenas limitações à propriedade com causa legal ${ }^{106}$.

Assim, nas limitações ao direito de propriedade impõe-se um comando genérico de fazer ou não fazer a diferentes titulares de uma situação jurídica do direito das coisas, comprimindo o conteúdo econômico das prerrogativas de determinado titular.

Outros doutrinadores ${ }^{107}$, contudo, consideram que as obrigações reais podem assumir qualquer natureza e, por consequência, não apenas no sentido positivo (fazer ou dar), mas também no sentido negativo, isto é, de tolerar ou de não fazer.

\section{A controvérsia a respeito dos direitos reais in faciendo}

Na sistemática adotada pelo Código Civil $^{108}$, as obrigações têm como objeto uma prestação de dar (dare), fazer (facere) ou não fazer (non facere).

Paulo Luiz Netto Lôbo ${ }^{109}$ entende que todas as obrigações civis são, no limite, obrigações de fazer, pois ao direito apenas interessa a ação, a atividade e o agir humano.

Nesse passo, afirma que o objeto da prestação de dar não seria a coisa, mas a ação do devedor de entregar ou restituir a coisa.

\footnotetext{
${ }^{106}$ Cita, como exemplos, as determinações impostas por plano diretor de município, no sentido de respeitar parâmetros de edificação.

${ }^{107}$ Cf. Edmundo Gatti (Derechos reales - teoria general, p. 117) e Antonio Celso Aguilar Cortez (Obrigações “Propter Rem” - Visão Contemporânea, p. 6).

${ }^{108}$ Artigos 233 a 285. São positivas as obrigações de dar e fazer. Negativas são as obrigações de não fazer ou tolerar. As obrigações de dar consistem na entrega ou restituição de uma coisa. Pode-se mencionar, como ilustração, o contrato de compra e venda, no qual o vendedor pode exigir do devedor o pagamento do preço, ao passo em que o comprador tem o direito à coisa. A obrigação de fazer é concretizada genericamente em um ato do devedor. É o caso de uma prestação de serviços. A obrigação de não fazer é a negativa típica. $\mathrm{O}$ devedor está obrigado a uma abstenção e permanece em situação omissiva.

109 Teoria geral das obrigações, p. 112. A classificação das obrigações em dar, fazer e não fazer, herdada do direito romano, é objeto de severas críticas pela doutrina. Observe-se, ademais, que nem sempre é possível identificá-las com clareza, dada a complexidade das relações sociais e negociais.
} 
O dever jurídico que decorre dos direitos reais consiste em obrigações negativas ${ }^{110}$. Destarte, o sujeito passivo do direito real de propriedade deve se abster de qualquer ingerência no direito alheio.

O direito real também pode implicar em um dever de tolerar (pati), isto é, de suportar determinada limitação ou ônus.

Na servidão de passagem, exemplo comumente suscitado pela doutrina, o titular do direito real sobre o prédio serviente deve tolerar a passagem em favor do prédio dominante, nos exatos termos da servidão constituída.

É acalorada a discussão a respeito da admissibilidade da figura do direito real in faciendo.

Fala-se em direitos reais in faciendo nos casos em que o sujeito passivo deve realizar uma prestação positiva, de dar ou fazer, em favor do titular de um direito real. Ao tratar da questão, os doutrinadores recorrem à figura do ônus real do direito germânico ("Reallast") e do ônus predial do direito suíço ("Grundlast") 111.

A noção de direitos reais in faciendo, para Edgardo Valera ${ }^{112}$, encerra uma contradição, pois sua admissão implicaria em relação de poderio sobre uma pessoa, o que obsta a essência dos direitos reais.

Edmundo Gatti ${ }^{113}$ considera que, em qualquer direito com origem romanista, pretender a possibilidade de um direito real in faciendo significa uma contradição metodológica, conceitual e terminológica. Assevera que, se um direito é real, não pode ser in faciendo, porque o não fazer é um conteúdo típico e exclusivo dos direitos pessoais.

\footnotetext{
${ }^{110} \mathrm{Na}$ verdade, essa conclusão tem como premissa a aceitação da teoria personalista, no sentido de que o direito real gera uma obrigação passiva universal, consistente no dever geral de abstenção da prática de qualquer ato que atinja o direito real.

111 O BGB contempla em seu artigo 1.105 a figura da "Reallast": "Um prédio pode ser onerado de modo que, àquele em favor do qual a oneração tem lugar, sejam satisfeitas, à custa do prédio, prestações periódicas (ônus real)".

${ }_{112}$ Obligaciones propter rem, p. 137.

${ }^{113}$ Derechos reales - teoría general, p. 108.
} 
A ideia era afastada pelos romanos, que manifestavam o aforismo servitus in faciendo consistere nequit. A máxima implicava que o direito real nunca poderia consistir em que o titular do prédio serviente fizesse algo em benefício do proprietário do prédio dominante, isto é, do titular do direito real de servidão.

A noção, explica Gatti ${ }^{114}$, não estava restrita às servidões, mas se estendia a todos os direitos reais.

Na Argentina a questão é abordada em termos peremptórios: o Código Civil daquele país afasta expressamente a possibilidade de direitos reais in faciendo e expressa, no seu artigo 497, que "no hay obligación que corresponda a derechos reales".

Para Manuel Henrique Mesquita não há sentido falar em direito real nos casos em que a coisa não está diretamente subordinada ao domínio de uma pessoa.

Não existe o elemento fulcral da realidade, qual seja, o poder direto e autônomo sobre uma coisa. Conclui afirmando que os direitos reais in faciendo consistem, pelo lado ativo, em puro direito de crédito e correspondem, pelo lado passivo, às obrigações propter rem $^{115}$.

Nessa linha de raciocínio, o conceito de obrigação real seria suficiente para abranger os casos em que o titular de um direito real se encontra obrigado, nessa qualidade, a realizar, reiteradamente ou não, determinada prestação em benefício de um terceiro.

Serpa Lopes enfrenta a questão ao analisar as noções de obrigações reais e de servidão ${ }^{116}$. Explica que os clássicos já separavam os institutos das servidões e das obrigações propter rem. Nas primeiras, o proprietário do prédio serviente limita-se a um conteúdo negativo, isto é, de deixar fazer. Quando, porém, houver um facere, tratar-se-á de uma obrigação real.

\footnotetext{
${ }^{114}$ Idem.

${ }^{115}$ Obrigações reais e ônus reais, p. 118.

${ }^{116}$ Curso de direito civil - direito das coisas, p. 52/54.
} 
Os anticlássicos, por sua vez, ampliariam o conceito de servidão originário do direito romano. Para essa corrente, encabeçada por Ripert e Rigaud, o proprietário do prédio serviente poderia assumir uma posição de pati ou de facere.

Após longa análise sobre as principais posições sobre o tema, arremata afirmando que as obrigações propter rem consistem em figura distinta e autônoma ${ }^{117}$; desse modo, seria impossível a admissão de direitos reais in faciendo.

O Código Civil de 1916 contemplava, entre os direitos reais, a figura da renda constituída sobre imóveis ${ }^{118}$. Para alguns autores, como Arnoldo Wald, o instituto coloca uma pá de cal sobre a discussão acerca da admissão dos direitos reais in faciendo, pois a lei expressamente estabelece uma hipótese na qual o titular de um direito real pode exigir do sujeito passivo, uma obrigação de conteúdo positivo ${ }^{119}$.

Orlando Gomes argumenta que o direito real in faciendo, embora excepcional, é admitido ${ }^{120}$. Utiliza como exemplo a servitus oneris ferendi, que consiste no direito de apoiar a construção no prédio vizinho e que, ao contrário do que ocorre com a generalidade das servidões, impõe ao proprietário do prédio serviente a conservação e reparação do muro de apoio.

Edmundo Gatti $^{121}$ refuta o argumento e sustenta que esse caso excepcional não implica uma quebra do princípio romano da servitus in faciendo consistere nequit. Isso porque o dever de conservar e reparar a parede que suporta a carga é meramente acessório da servidão, cujo único conteúdo é a possibilidade de apoio de um edifício no vizinho.

\footnotetext{
117 Op. cit., p. 55. Nas palavras do autor: "nem a obrigação propter rem pode ser parificada às servidões, pois que, em seu conteúdo, não se concilia com a idéia de servidão, nem é possivel transformá-la em direito real, atento a não se ajustar sua eficácia erga omnes a que circunda os direitos reais".

${ }^{118}$ O instituto era regulado pelos artigos 749 a 754 do Código Civil de 1916 e não foi contemplado pelo atual Código Civil. Como bem explicado por Caio Mário da Silva Pereira, "pela constituição de renda como direito real, uma pessoa entrega um imóvel a outra, com o encargo de lhe fornecer ou a terceiro uma renda periódica. (...) constituído o direito real, reveste-se do atributo da seqüela. Conseguintemente, o adquirente do imóvel está sujeito ao pagamento da renda independentemente de a isto comprometer-se. Estará obrigado, mesmo que o título aquisitivo o dispense, enquanto não cancelado o registro" (Instituições de direito civil. Vol. IV, p. 195).

${ }^{119}$ Curso de direito civil brasileiro - direito das coisas, p. 26.

${ }^{120}$ Direitos reais, p. 25.

${ }^{121}$ Op. Cit., p. 110.
} 


\section{A taxatividade das obrigações reais}

Como observa Trabucchi ${ }^{122}$, predomina o entendimento de que as obrigações propter rem decorrem da lei e, por consequência, estão submetidas ao princípio da taxatividade ${ }^{123}$; a autonomia da vontade, portanto, não criaria obrigações dessa natureza $^{124}$.

O argumento principal, como destaca Serpa Lopes, é o de que "não se pode reconhecer ao indivíduo a faculdade de tornar sucessora num débito uma pessoa dêle insciente ou contra a sua própria vontade ${ }^{\prime 125}$.

Destaca o autor, todavia, que esse caráter de tipicidade não representa um princípio tranqüilo e indica que, na Itália, há um movimento jurisprudencial em sentido inverso, admitindo a criação de obrigações propter rem mediante convenção ${ }^{126}$.

Manuel Henrique Mesquita também considera que a taxatividade das obrigações reais é a única solução razoável ${ }^{127}$. Pondera que, acaso admitida, a liberdade de criação de obrigações reais "seria a porta aberta para a introdução de todas as peias e gravames que o princípio da taxatividade pretende precisamente evitar”.

\footnotetext{
${ }^{122}$ Istituzioni di diritto civile, p. 533: "la dottrina e la giurisprudenza sono orientate nel senso che anche le obbligazione propter rem costituiscano figure tipiche (numerus clausus)". Também Edmundo Gatti (Derechos reales - teoría general, p. 116): "El ministerio de la ley desempeña un factor decisivo (o exclusivo) en el nacimiento y vicisitudes de la obligación real, ya que el nacimiento se produce ope legis”.

${ }^{123}$ Nesse sentido, confira-se Orlando Gomes (Direitos reais, p. 28).

${ }^{124}$ Edgardo Valera (Op. cit., p. 139).

${ }^{125} \mathrm{O}$ fundamento da taxatividade das obrigações reais é bem desenvolvido por Luciano de Camargo Penteado (Direito das coisas, p. 117): "justifica-se o número fechado em vista de duas razões básicas. A estrutura do dever de causa real é apta a atingir os futuros adquirentes do bem. Não seria conforme ao sistema que terceiro fosse obrigado por ato alheio sem fonte legal autônoma a permitir isso. Seria um caso de ultra eficácia de relação obrigacional, para além das partes contratantes, em prejuízo do sujeito, o que é vedado. Ocorreria o absurdo de duas partes criarem um dever propter rem que poderia atingir terceiro sem que este tivesse possibilidade de conhecê-lo previamente. Sendo legais as hipóteses em que este dever se estende, isto não ocorre. Dada a vinculação do dever com coisas, é muito importante que assim o seja para haver agilidade constante nas trocas patrimoniais. Além disso, como são obrigações fortemente conectadas à própria situação de direito das coisas, devem obedecer ao seu regime geral, que é o da taxatividade. Este visa justamente permitir circulação de bens sem grandes travas e impedimentos, com agilidade e impulso fornecidos à economia”.

${ }^{126}$ Apesar dessa observação de Serpa Lopes, Manuel Henrique Mesquita (Obrigações reais e ônus reais, p. 283 e seguintes) explica que essa orientação jurisprudencial italiana mostrou-se equivocada e, assim, foi abandonada. Desse modo, vigora em grande parte da doutrina italiana considera o princípio da taxatividade se aplica às obrigações reais.

127 Op. cit., p. 284 e 288.
} 
Reconhece, todavia, que a regra admite alguns temperamentos, de sorte que aos particulares é permitida a intervenção na modelação do estatuto dos direitos reais nos casos em que a lei admite ${ }^{128}$.

Menciona, como ilustração, as servidões que estabelecem, no título constitutivo, que o titular do direito real sobre o prédio serviente é obrigado a custear as obras de conservação e de manutenção da servidão.

Em matéria condominial, na opinião de Milena Donato Oliva, é possível vislumbrar uma mitigação do princípio da taxatividade das obrigações propter rem $^{129}$.

André Pinto da Rocha Osório Gondinho assevera a prevalência do princípio da taxatividade para as obrigações propter rem. Distingue, todavia, as obrigações reais meramente legais daquelas em que há uma autorização na lei para o estabelecimento voluntário de relações de caráter misto, como ocorre nas obrigações decorrentes de uma convenção de condomínio ${ }^{130}$.

Para demonstrar o seu raciocínio, o autor analisa a convenção de um empreendimento imobiliário situado na cidade de Petrópolis, estado do Rio de Janeiro, que contempla uma série de normas de convivência, as quais determinam, dentre outros pontos, que os projetos de construção, reformas e modificações devem ser submetidos a uma comissão de obras.

Sustenta que tais obrigações, embora convencionais, têm natureza propter rem, pois vinculam os titulares dos direitos reais sobre as unidades, ainda que ocorra a transmissão do direito.

\footnotetext{
${ }^{128}$ Op. cit., p. 290. Exemplifica o autor: "Noutros casos, a margem de actuação deixadas aos particulares possibilita a criação, no âmbito dos direitos reais, de obrigações de dare ou facere, isto é, de verdadeiras obrigações propter rem. É o que se passa, por exemplo, no direito de superfície, quando a lei diz (art. $1530^{\circ}$, $n^{o}$ 1) que no acto de constituição pode convencionar-se, a título de preço, o pagamento pelo superficiário de uma prestação anual, perpétua ou temporária. E é o que se passa também em matéria de servidões, quando a lei (art. $\left.1567^{\circ}\right)$ permite que no título constitutivo se convencione que as obras necessárias ao exercício da servidão serão custeadas pelo proprietário serviente".

${ }^{129}$ A responsabilidade do adquirente pelos encargos condominiais na propriedade horizontal, p. 95.

${ }^{130}$ Direitos reais e autonomia da vontade, p. 126. "há autorização legal para o estabelecimento voluntário de tais relações de caráter misto - v.g. as obrigações decorrentes da convenção de um condomínio sujeito à Lei 4.591/64 -, hipótese na qual haverá a modelação do conteúdo e exercício do direito real em questão".
} 
Considera que apenas terão validade se encontrarem aquilo que denomina de "um critério seguro de legitimidade no bem-estar da comunidade condominial" $" 131$.

Antonio Junqueira de Azevedo aborda o tema em interessante parecer proferido em processo que versa sobre restrições convencionais em loteamento ${ }^{132}$.

Após afirmar que tais limitações registradas na matrícula do imóvel consistiriam em obrigações propter rem, argumenta o professor que a obrigação está sujeita a um juízo de razoabilidade e da finalidade do seu conteúdo ${ }^{133}$.

Nessa esteira, forçoso admitir que as obrigações reais têm, em regra, sua origem na lei.

Em situações especiais, entretanto, é possível que os particulares estabeleçam obrigações reais, as quais estarão, sempre, sujeitas à verificação de sua validade.

\section{A transmissão da obrigação propter rem: a ambulatoriedade}

Fixada a premissa de que a obrigação propter rem surge em razão da titularidade de uma situação jurídica real, importa analisar o que ocorre naqueles casos em que há a transferência desse direito.

\footnotetext{
${ }^{131}$ Idem. Nas palavras do autor: "As restrições convencionais à propriedade do titular da unidade autônoma, mediante a constituição de obrigações propter rem pela convenção condominial, só se justificam quando correspondem à necessidade de se evitar conflitos de interesse entre os titulares dos direitos reais correlacionados, como, por exemplo, aqueles decorrentes do mau uso da propriedade, nas relações de vizinhança". Igual é o entendimento de Milena Donato Oliva (Op. cit., p. 98), para quem a liberdade inserta na autonomia da vontade, pelo fato de vincular futuros consortes, submete-se a um rigoroso controle valorativo, averiguando-se, em concreto, seu merecimento de tutela.

${ }^{132} \mathrm{O}$ caso abordado pelo ilustre professor tratava de mandado de segurança impetrado contra ato do Secretário Municipal da Habitação e Desenvolvimento Humano de São Paulo, o qual havia negado atendimento ao pedido de construção de imóvel apresentado pelo impetrante. Em breve resumo, apoiou-se o impetrado em dispositivo legal, o qual determinava que as restrições convencionais deveriam ser obedecidas quando maiores do que as exigidas pela legislação de parcelamento, uso e ocupação do solo. O terreno em tela consistia em imóvel situado à Avenida Brasil, na Capital de São Paulo, sobre o qual incidiam uma série de restrições criadas pela então loteadora Cia. City, ao lançar o "Jardim América", em 1917. No parecer, Antonio Junqueira de Azevedo analisa, dentre outras questões, a natureza jurídica das restrições convencionais de loteamento, bem assim as eventuais condições de permanência.

${ }^{133} \mathrm{Na}$ realidade, questiona tal natureza em relação à hipótese versada no parecer, mas com base em argumentos específicos àquele caso e que não interessam ao presente trabalho.
} 
Interessa averiguar, portanto, se a obrigação propter rem segue o destino do direito real sempre que se opere uma mutação subjetiva na titularidade.

Não há maiores dúvidas quando a obrigação ainda não se encontra constituída na data da transmissão do direito real; em tais hipóteses, sempre poderá ser exigida do novo titular ${ }^{134}$.

Todavia, questiona-se a responsabilidade pelas obrigações já nascidas - e não cumpridas - no momento do ato translativo do domínio.

A questão é tratada com simplicidade pela maioria dos doutrinadores pátrios, que costumam ressaltar, sem maiores questionamentos, o caráter ambulatório das obrigações reais; predomina, entre nós, a orientação no sentido de que a obrigação real acompanha o direito real sempre que o titular o transmita a outra pessoa ${ }^{135}$.

Como visto alhures, há quem, inclusive, utilize a expressão obrigação ambulatória para designar as obrigações reais e, destarte, considere tal atributo como característica fundamental do instituto.

\footnotetext{
${ }^{134}$ Manuel Henrique Mesquita (Op. cit., p. 312) utiliza o usufruto como exemplo: "(o usufrutuário) não é devedor do comportamento que a lei lhe impõe no artigo $1472^{\circ}, n^{\circ} 1$ (promover as reparações ordinárias indispensáveis para a conservação da coisa), pelo simples fato de ter adquirido o direito de usufruto. A relação obrigacional (que tem como credor o proprietário de raiz) só nasce quando a coisa sujeita a usufruto carecer de reparações. Antes disso, o usufrutuário não está obrigado a realizar qualquer prestação; está apenas sujeito, na qualidade de titular de um ius in re, a um regime ou estatuto de que podem nascer relações obrigacionais. (...) Deve entender-se, portanto, que o problema da sucessão da obrigação propter rem - de origem legal ou negocial, pouco importa - apenas surge quando, verificados os pressupostos que no estatuto do direito real se mencionem e constituída, assim, a relação obrigacional, ocorra um acto translativo do direito real antes do cumprimento da obrigação".

${ }^{135}$ Para Orlando Gomes (Obrigações, p. 21) as obrigações propter rem "caracterizam-se pela origem e transmissibilidade automática. Consideradas em sua origem, verifica-se que provêm da existência de um direito real, impondo-se ao seu titular. Esse cordão umbilical jamais se rompe. Se o direito de que se origina é transmitido, a obrigação o segue, seja qual for o título translativo (...) Conquanto não se enquadrem rigorosamente na categoria das obrigações ambulatórias, que constituem a mais frisante exceção ao princípio da determinação dos sujeitos da relação obrigacional, as obrigações reais distinguem-se, sob esse aspecto, pelo fato de admitirem, por sua própria natureza, a substituição do sujeito passivo, que, assim, se determina mediatamente. Para caracterizar incisivamente tais obrigaçães na sua vinculação ao bem, podese dizer, figurativamente, que têm seqüela.". Nesse mesmo sentido, Serpa Lopes (Curso de direito civil direito das coisas, p. 58), Luciano de Camargo Penteado (Direito das coisas, p. 116), Sílvio Rodrigues (Direito civil - parte geral das obrigações, p. 101) e Carlos Roberto Gonçalves (Direito civil brasileiro direito das coisas, p. 21).
} 
Alberto Trabucchi ${ }^{136}$, a exemplo da doutrina nacional, entende que a obrigação propter rem é sempre transmitida ao adquirente do direito real. A obrigação real, portanto, seria conexa ao direito real, submetida ao princípio de que o acessório segue o principal.

Roxana B. Cánfora afirma que, com a transmissão da coisa, ocorre a substituição do sujeito passivo da relação obrigacional independentemente da vontade do credor $^{137}$.

No direito comparado, contudo, o tema é controverso ${ }^{138}$, sendo identificadas diferentes posições.

Biondo Biondi, em posição diametralmente oposta, sustenta que a obrigação real nunca seria ambulatória. Para o autor, uma vez radicada a obrigação em determinado sujeito, cessa a ambulatoriedade e sua transmissão transcorre pelas causas ordinárias da teoria geral das obrigações ${ }^{139}$.

Para Antunes Varela, a substituição do titular passivo opera-se por via indireta, isto é, com a aquisição do direito sobre a coisa a que o dever de prestar se encontra ligado. Assevera que tal substituição, contudo, não ocorrerá se a obrigação estiver autonomizada $^{140}$.

Eduardo Sócrates Castanheira Sarmento Filho, em raciocínio semelhante, alega que, em caso de alienação do bem, o responsável continua vinculado e responsável pela dívida, não obstante a transmissão do seu direito ${ }^{141}$.

\footnotetext{
${ }^{136}$ Istituzioni di diritto civile, p. 532. Também Edgardo Valera (Obligaciones propter rem, p. 143).

${ }^{137}$ Obligaciones reales, p. 11. A autora diz que as características próprias das obrigações propter rem são a faculdade de abandono da coisa e a ambulatoriedade.

${ }^{138}$ Merece destaque a obra de Manuel Henrique Mesquita que aborda o assunto com bastante profundidade (Obrigações reais e ônus reais, p. 307 e ss.).

${ }^{139}$ Citado e criticado por Manuel Henrique Mesquita: "Ambulatória não é a obrigação, mas a possibilidade do seu nascimento. A obrigação surge a cargo de quem for titular do direito no momento em que se verifique a circunstância prevista em lei para o seu nascimento. Mas, uma vez surgida a obrigação, cessa toda a ambulatoriedade; radicada num determinado sujeito, segue o destino de qualquer outra obrigação; transmite-se aos herdeiros, independentemente da transmissão do direito real".

${ }^{140}$ Direito das Obrigações, p. 46.

${ }^{141}$ A responsabilidade pelo pagamento de cotas condominiais no regime da propriedade horizontal, p. 88 .
} 
Baseando-se em uma série de exemplos hipotéticos, Manuel Henrique Mesquita desconstitui a regra geral de que a ambulatoriedade é inerente a todas as obrigações reais $^{142}$.

Após analisar as diferentes posições acerca da transmissibilidade da obrigação real, o autor sustenta que sempre que o conteúdo da obrigação consistir numa prestação de fazer que imponha a prática de atos materiais na coisa deve ser reconhecido o seu caráter ambulatório ${ }^{143}$.

E, prossegue, todas as demais obrigações propter rem, devem ser consideradas, em princípio, não ambulatórias. Para chegar a tal conclusão, diz que muitas vezes a dívida propter rem representa o correspectivo de um uso ou fruição que coube ao alienante, que deve, por conseguinte, suportar o custo que a coisa lhe proporcionou ${ }^{144}$.

Não se justificaria, ademais, que o adquirente tivesse o ônus de averiguar o passado, isto é, de investigar a pendência de obrigações. Em sua concepção, a ambulatoriedade não consistiria em característica fundamental das obrigações reais ${ }^{145}$.

\section{O traço essencial do instituto seria apenas a taxatividade ${ }^{146}$.}

\footnotetext{
${ }^{142}$ Op. cit., p. 345. A ponderação do renomado autor português é interessante: "a doutrina ainda não se libertou, nesta matéria, de um claro vício conceitualista: em vez de partir, com vista à formulação do conceito de obrigação real, das soluções concretas, como o impõe uma correcta e hoje indiscutida metodologia jurídica, tem feito precisamente o contrário, aceitando um conceito tradicional e todas as suas implicações, sem o submeter, pela via de ponderação dos interesses que se entrechocam nas situações e casos por ele abrangidos, à necessária reflexão crítica”.

${ }^{143}$ Idem, p. 330. Nesses casos, afirma o autor que os pressupostos da obrigação estão materializados ou radicados na própria coisa. Observa, entretanto, que o alienante não está desonerado, mas agora sob o regime culposo da responsabilidade civil.

144 Idem, p. 337.

145 Idem, p. 346 a 348: “A natureza real de uma obrigação significa apenas (...) que ela tem origem no estatuto do ius in re. Não significa que a relação obrigacional tenha de ficar permanentemente ligada à relação de soberania de cujo regime promana. Ora, o que o regime de determinadas obrigações (fixado por via interpretativa, à luz dos interesses em jogo) nos m ostra é que elas se autonomizam no preciso momento em que se verificam ou concretizam os pressupostos de que dependem. Trata-se de obrigações que, mal se constituem, imediatamente se separam ou desprendem da sua matriz, adquirindo total independência. E, como obrigações autonomizadas, fixam naturalmente sujeitas, quer quanto à transmissão, quer quanto aos demais aspectos do seu regime jurídico, à disciplina geral das relações creditórias, das quais apenas se distinguem pela fonte de onde emergem."

${ }^{146}$ Idem: “deve, portanto, entender-se que as obrigações que decorrem do estatuto dos direitos reais, quer fiquem permanentemente ligadas à relação de soberania que lhes dá origem (obrigações ambulatórias), quer dela se autonomizem no momento em que se verifiquem os pressupostos de que dependem, estão sempre sujeitas ao princípio da taxatividade. E isto basta para, em confronto com as obrigações vulgares, justificar o seu enquadramento numa categoria conceitual própria - a categoria das obrigações reais, ob rem, ou propter rem".
} 
O que importa, assim, não é estender aos adquirentes a responsabilidade pelas dívidas vencidas, mas a obrigação propter rem que acompanha o estatuto do direito real.

Luís A. Carvalho Fernandes, ao analisar o debate entre os que defendem e os que não defendem a ambulatoriedade ou não das obrigações propter rem, considera que nenhuma das posições é satisfatória, pois todas elas ignoram os interesses em presença $^{147}$.

Adverte que a solução defendida por Manuel Henrique Mesquita é aceitável, mas que, em rigor, só as obrigações ambulatórias merecem o qualificativo de reais.

Milena Donato Oliva, analisando o tema sob o prisma do Código Civil de 2002, considera que deve prevalecer a orientação no sentido de que as obrigações já autonomizadas não sejam transferidas ao novo titular ${ }^{148}$.

Castro Vítores explica que na doutrina suíça também há uma discussão semelhante àquela que ocorre entre os italianos acerca da ambulatoriedade ${ }^{149}$.

Cita Deschenaux, para quem não há razão que justifique que a ambulatoriedade seja o sentido da caracterização da obrigação real. Para esse autor, se a causa da obrigação se encontra no direito cujo proprietário originário era titular na época do nascimento ou vencimento, não há motivo para que se defenda a extinção da dívida.

\footnotetext{
${ }^{147}$ Lições de Direitos Reais, p. 184. Ainda acerca dessa classificação, A. Santos Justo (Direitos reais, p. 89) menciona a opinião de Rui Pinto Duarte para quem "os critérios de M. Henrique Mesquita podem ser tomados como indiciários - mas nãos mais do que isso".

${ }^{148}$ Op. cit. p. 80. “(...) pode-se inferir que o legislador de 2002 adotou como disciplina geral aplicável às obrigações reais a que impõe ao titular da situação subjetiva real a responsabilidade apenas pelos débitos nascidos na vigência de seu direito, cabendo ao alienante, por isso mesmo, arcar com as dividas surgidas antes da alienação. Desse modo, pode-se sustentar que o Código Civil de 2002, em seu art. 502, estipulou como regra geral, que as obrigações reais, uma vez constituídas, se autonomizam e se incorporam no patrimônio do titular da situação jurídica subjetiva real, que se torna responsável pelo adimplemento dos débitos propter rem. Não obstante ocorra posterior mutação subjetiva do direito real, o titular da obrigação propter rem não se altera". Dispõe o artigo 502 do Código Civil que "o vendedor, salvo convenção em contrário, responde por todos os débitos que gravem a coisa até o momento da tradição".

${ }^{149}$ La obligación real en el derecho de bienes, p. 722.
} 
Giovanni Balbi ${ }^{150}$, ao abordar a ambulatoriedade das obrigações propter rem, traça um quadro de hipóteses e oferece diferentes soluções. Afirma que se o direito real é transmitido antes que o credor possa exigir o cumprimento da obrigação, o adquirente está obrigado, e o alienante, liberado.

Caso a transferência ocorra quando o cumprimento, já devido, ainda não tenha sido iniciado, o sucessor estará obrigado. O alienante, por sua vez, responderá pelas consequências do inadimplemento verificadas enquanto era o titular do direito real.

Se a transferência ocorre quando o cumprimento foi iniciado, mas não terminado, o adquirente deve ultimar o cumprimento, mas não responde pelo comportamento do anterior titular.

Por fim, quando o comportamento devido já foi realizado, as eventuais consequências não se transmitem ao adquirente, pois se trata de uma relação de obrigação comum.

Em nossa concepção, a ambulatoriedade não pode ser considerada uma característica essencial das obrigações propter rem. O elemento que realmente as identifica é apenas o surgimento em decorrência da titularidade de uma situação jurídica dos direitos reais.

Mas isso não implica, forçosamente, que aquele que figurar como titular de um direito real deva assumir as obrigações vencidas anteriormente à transmissão do direito. Assume, por óbvio, as obrigações não constituídas, as quais estão vinculadas ao direito real.

Para que haja essa responsabilidade pelos débitos vencidos é necessário que exista uma disposição legal específica, como ocorre nos casos de débito condominial $^{151}$.

\footnotetext{
${ }^{150}$ Le obbligazioni propter rem, p. 139 e ss.

${ }^{151}$ Cf. artigo 1.345 do Código Civil.
} 
Nessa hipótese, o legislador, considerando os interesses em jogo, considerou que seria interessante que o adquirente respondesse pelos débitos do alienante, inclusive multa.

Mas se não houvesse a mencionada disposição, consideraríamos que o adquirente seria responsável apenas pelos débitos que vencessem após a aquisição do bem, como, aliás, ocorre em Portugal.

Veja-se, por exemplo, o sistema tarifário da Companhia de Saneamento Básico do Estado de São Paulo - SABESP, estabelecido pelo Decreto ${ }^{\circ} 41.446 / 96^{152}$. Ainda que se considere o dever de pagar a tarifa uma obrigação propter rem $^{153}$, não é admissível atribuir a ambulatoriedade em relação aos débitos pretéritos, pois inexiste qualquer previsão legal nesse sentido. É a orientação da jurisprudência do Egrégio Tribunal de Justiça do Estado de São Paulo ${ }^{154}$.

\section{Renúncia liberatória e abandono}

\subsection{Aspectos gerais}

Estabelece o artigo 1.275, II, do Código Civil que a renúncia é uma das formas de perda da propriedade.

\footnotetext{
${ }^{152} \mathrm{O}$ artigo 19, parágrafo segundo, do regulamento estabelece que "é de responsabilidade solidária do proprietário do imóvel, o ressarcimento de débitos de faturas/contas não quitadas por eventual usuário ocupante do mesmo".

${ }^{153}$ A tarifa é devida apenas em caso de existência de ligação de água e esgoto no imóvel. É possível admitir, em tese, um imóvel desprovido desse serviço e, portanto, não sujeito à cobrança de qualquer encargo.

${ }^{154}$ Confira-se: "TARIFA - Água e esgoto - Prestação de serviços - Cautelar inominada e cognitiva declaratória de inexistência de relação jurídica, com pedido contraposto - Recurso preparado - Obrigação de pagar que é de natureza pessoal, não "propter rem" - Incide o princípio da relatividade dos efeitos contratuais - Contrato de prestação de serviços vincula solidariamente os antigos proprietários e a locatária, e não o atual proprietário (Decreto Paulista $n^{\circ} 41446 / 96$, artigo 19, parágrafo segundo) Solidariedade que não se presume, decorre da lei ou da vontade das partes - Pelos direitos reais, as obrigações "propter rem" obedecem ao princípio da numeração restrita, de modo que não se conhece outros tipos além dos configurados na lei, porquanto não podem ser constituídos pelas partes - Cobrança pela ré em relação ao autor da tarifa nascida em agosto de 1995, à míngua de contratação entre as partes em litígio àquela época - Descabimento - Preliminar rejeitada - Recurso improvido." (Tribunal de Justiça do Estado de São Paulo - Ap. Cível no 948.775-0/2 - São Paulo - 25a Câmara de Direito Privado - Relator Antônio Benedito Ribeiro Pinto - J. 18.06.07 - v.u). Veja-se que o acórdão, acertadamente, decidiu que a obrigação de pagar as tarifas de água e esgoto não se transmite ao novo proprietário do bem, por ausência de disposição legal nesse sentido. Vale dizer, a solidariedade pelo débito não se presume. Todavia, a fundamentação da decisão parece-nos incorreta, pois o argumento utilizado pelo relator foi o de que a obrigação não seria transmitida ao novo titular e, portanto, não seria propter rem. Em nossa concepção, a obrigação é propter rem, contudo, não é ambulatória.
} 
Trata-se, conforme conceito de Orlando Gomes ${ }^{155}$, de ato pelo qual o proprietário declara explicitamente o propósito de despojar-se do seu direito. É um negócio jurídico não receptício, de sorte que a produção dos seus efeitos independe da concorrência de outra vontade, isto é, da aceitação de quem quer que seja.

Exige-se, para os bens imobiliários, o registro do ato ${ }^{156}$; também é necessária a escritura pública para imóveis de valor superior a trinta vezes o maior salário mínimo vigente no País ${ }^{157}$.

A renúncia diferencia-se do abandono, que é o ato pelo qual o proprietário se desfaz da coisa que lhe pertence, por não querer conservá-la em seu patrimônio. Há, neste último caso, uma intenção de abandonar, evidenciada por atos inequívocos. Porém, inexiste formalidade.

Para sua configuração, portanto, é necessária a derrelição e a intenção $\operatorname{abdicativa~}^{158}$.

Observa José de Oliveira Ascensão ${ }^{159}$ que a renúncia está inserida no direito de disposição garantido ao proprietário que tem o direito de decidir pela conveniência, ou não, da manutenção da propriedade.

\footnotetext{
155 Direitos Reais, p. 211.

${ }^{156}$ Conforme expressa determinação do artigo 1.275, parágrafo único, do Código Civil.

${ }^{157}$ Artigo 108.

${ }^{158} \mathrm{O}$ abandono também está previsto no artigo 1.275 , III, como forma de perda da propriedade. O artigo 1.276 estabelece uma importante presunção absoluta de abandono na hipótese de o proprietário, cessados os atos de posse, deixar de satisfazer os ônus fiscais. O mesmo dispositivo regula a possibilidade de arrecadação do imóvel abandonado em favor da União ou do Município, conforme se tratar de bem rural ou urbano. O Enunciado n 242 do Conselho da Justiça Federal, aprovado na III Jornada de Direito Civil, explicita que " $a$ aplicação do art. 1.276 depende do devido processo legal, em que seja assegurado ao interessado demonstrar a não-cessação da posse". Já o enunciado $\mathrm{n}^{\circ} 243$ prescreve que "a presunção de que trata o $\$ 2^{\circ}$ do art. 1.276 não pode ser interpretada de modo a contrariar a norma-princípio do art. 150, IV, da Constituição Federal". Trata-se do princípio constitucional que veda a utilização do tributo com efeito de confisco. O Projeto de Lei $n^{\circ}$ 276/2007 expressa que a presunção é relativa e, portanto, admite prova em contrário.

${ }^{159}$ Direito civil. Reais, p. 406. Nas palavras do autor: "a propriedade é um direito subjectivo e não uma função ou um encargo. Só o proprietário é juiz da conveniência ou inconveniência da manutenção da sua situação, não se distinguindo consoante o objeto é móvel ou imóvel. O abandono e a renúncia têm por isso sempre de se afirmar como a última defesa que resta ao particular perante o avolumar das exigências legais".
} 
A extinção do direito de propriedade decorrente da renúncia também é admitida no direito comparado ${ }^{160}$.

Maria Helena Diniz sustenta que a renúncia é realizada em favor de terceira pessoa, que não precisa manifestar sua aceitação. Assevera que, desde que não acarrete prejuízos a terceiros, a renúncia ao direito de propriedade é sempre possível ${ }^{161}$.

11.2. Das consequências da renúncia em relação às obrigações propter rem

Conforme já abordado em capítulo próprio, a vinculação à coisa é uma característica fundamental da obrigação propter rem. O devedor fica sujeito a uma determinada prestação pela simples condição de titular de um direito real.

Desse modo, consoante raciocínio desenvolvido por Sílvio Rodrigues, o devedor se libera da obrigação, se renunciar a esse direito ${ }^{162}$. Para Antunes Varela, a possibilidade de exoneração do devedor é corolário das obrigações reais ${ }^{163}$.

Washington de Barros Monteiro afirma que ônus reais sobremaneira gravosos, fiscais muito pesados ou gastos vultosos para a utilização podem determinar o abandono $^{164}$.

Cita exemplo de Martin Wolff, o qual relata que, na Alemanha, em época de inflação, diversos proprietários optavam pelo abandono de suas propriedades, por não se sentirem capazes de mantê-las de acordo com as disposições administrativas referentes à segurança dos prédios.

\footnotetext{
${ }^{160}$ Confira-se Manuel Henrique Mesquita (Obrigações reais e ônus reais, p. 376). Mas para o Código Português não é admitido: "no plano do direito constituído, porém, a interpretação sistemática da lei não fornece apoio para a livre renunciabilidade do domínio sobre imóveis. Embora o artigo $1305^{\circ}$ declare, em termos genéricos, que o proprietário tem o poder de dispor das coisas que lhe pertencem, existem outros preceitos de onde claramente se infere que o legislador não admite a extinção do direito de propriedade sobre imóveis pela renúncia".

${ }^{161}$ Curso de direito civil brasileiro - $4^{\circ}$ Vol., p. 181.

${ }^{162}$ Op. cit., p. 99. Diz o autor que "o abandono da coisa, por parte do devedor, o libera da dívida, pois ele estava preso a uma obrigação apenas em virtude de sua condição de proprietário, que não mais desfruta".

${ }^{163}$ Diz o autor: "como a obrigação depende do poder que o obrigado tem sobre certa coisa, a lei reconhecelhe, em alguns casos, a possibilidade de se exonerar, renunciando ao poder sobre a coisa. É o chamado abandono liberatório - um ato pelo qual o devedor, renunciando ao direito sobre a coisa, se exonera da obrigação correlativa" (Obrigações, p. 47).

${ }^{164}$ Curso de direito civil - direito das obrigações, p. 170.
} 
A situação é bem explicada por Manuel Henrique Mesquita ${ }^{165}$ : "se a ordem jurídica assegura aos particulares determinado monopólio sobre as coisas - um monopólio correspondente aos poderes contidos nos direitos reais de que podem ser objetcto -, mas a par disso, lhes impõe obrigações que funcionam como uma espécie de 'custo' ou 'preço' das vantagens que auferem, compreende-se perfeitamente que o titular de um ius in re, caso entenda que o desvalor das obrigações não é compensado pelo valor das vantagens proporcionadas pelo direito, possa renunciar à sua posição de soberania em benefício do credor, como forma de se libertar do cumprimento daquelas vinculações".

O assunto, contudo, não é simples e merece reflexão.

Milena Donato Oliva afirma que há dois posicionamentos ${ }^{166}$. O primeiro considera que o devedor de obrigação propter rem, ao renunciar à titularidade do direito real, exonera-se das dívidas nascidas, liberando-se dos vínculos obrigacionais que foram constituídos na constância da relação subjetiva real.

O outro posicionamento sustenta que a renúncia do direito real se opera em favor do credor, exonerando, da mesma forma, o devedor das obrigações propter rem nascidas. A situação corresponderia a uma obrigação facultativa ${ }^{167}$.

Esta última hipótese, afirma Manuel Henrique Mesquita, consiste na renúncia liberatória, ou seja, um ato praticado em benefício do credor de determinada obrigação propter rem: “em vez de realizar a prestação que está vinculado, o devedor põe à disposição do credor o próprio direito real de cujo estatuto a obrigação emerge. É a chamada renúncia liberatória, admitida pela generalidade da doutrina como uma conseqüência que logicamente decorre do fundamento das obrigações propter rem” ${ }^{168}$.

${ }^{165}$ Ob. cit., p. 362.

${ }^{166}$ A responsabilidade do adquirente pelos encargos condominiais na propriedade horizontal, p. 81-83.

${ }^{167}$ A obrigação facultativa tem por objeto uma única prestação e dá ao devedor a faculdade de substituir essa prestação por outra. Há, assim, uma prestação principal e outra acessória. Em caso de nulidade ou perdimento do objeto da obrigação principal, não pode o devedor exigir o cumprimento da acessória.

${ }^{168}$ Op. cit., pág. 382. Não se confunde com o abandono puro e simples. No abandono liberatório, ou renúncia liberatória, o devedor propter rem precisa notificar sua vontade ao credor; o que implica, assim, uma declaração de vontade. É um negócio oneroso e realiza-se pela via de uma declaração unilateral receptícia. Para o autor, é uma faculdade (ou direito potestativo) que assiste ao devedor propter rem e cujo exercício o credor não pode impedir. 
Entende Milena Donato Oliva que nenhuma dessas soluções é adequada ao sistema brasileiro. Isso porque os débitos oriundos da obrigação propter rem se incorporam ao patrimônio do devedor, tal como um outro passivo qualquer ${ }^{169}$.

Dessa forma, prossegue, a renúncia produz efeitos apenas para o futuro, "desvinculando o titular do direito real que emerge a obrigação real de sua fonte". Assim, "trata-se a renúncia ao direito real de faculdade atribuída ao sujeito passivo da obrigação propter rem para liberta-se de sua fonte, mas não tem o condão de extinguir os débitos passados, já nascidos e incorporados ao patrimônio".

Para Edmundo Gatti ${ }^{170}$, em se tratando de prestações propter rem sucessivas, o devedor só responde com todo o seu patrimônio, para aquelas obrigações que venceram ao longo do período em que se manteve como titular do direito real. Pelas anteriores, contudo, responde a coisa.

Carlos Alberto Dabus Maluf, comentando artigo publicado por Nelson Kojranski, rechaça posição adotada por Oficial Registrador no Estado de São Pauo, o qual exigia a aprovação específica em Assembléia Condominial para registrar a renúncia de um flat $^{171}$.

${ }^{169}$ Manuel Henrique Mesquita expressa igual entendimento: "em princípio, o devedor propter rem responde pelo cumprimento da obrigação com todo o seu patrimônio. Não há, com efeito, qualquer razão para não aplicar aqui a regra que responsabiliza pelas dividas de uma pessoa todos os seus bens susceptiveis de penhora." (p. 361). Também Paulo Carneiro Maia (Obrigação propter rem, p. 459), com apoio em Francesco Ferrara, afirma que "enquanto obrigado permanece vinculado pela relação, responde não só com a coisa, mas com o seu patrimônio por inteiro".

${ }^{170}$ Derechos reales - teoría general, p. 116. Nesse mesmo sentido, observa Sílvio da Sálvio Venosa (Direito civil - teoria geral das obrigações, p. 37-38) que "devemos ter cuidado, no entanto, com a afirmação genérica de que todas as ligações desta natureza admitem o abandono liberatório, isto é, liberam o devedor com o abandono da coisa. Não é com todas as obrigaçães propter rem que isso acontece, como no já citado das despesas de condomínio, em que o abandono por parte do proprietário não o libera da dívida".

${ }^{171}$ A propriedade no Código Civil de 2002: principais limitações e renúncia, p. 90. A fundamentação utilizada pelo Registrador, relata o autor, encontra-se no $\S 5^{\circ}$ do artigo 12 da Lei $n^{\circ} 4.591 / 64$, segundo o qual "a renúncia de qualquer condômino aos seus direitos, em caso algum valerá como escusa para exonerá-lo dos seus encargos". Essa posição, ao que parece, não é isolada. Flauzilino Araújo dos Santos (As despesas comuns e a garantia de funcionamento), registrador imobiliário na Capital de São Paulo, considera que "Pese ser a renúncia ao direito de propriedade um ato personalíssimo, em que a manifestação expressa da vontade do titular de domínio que não o quer mais é soberana, para o qual, se exige apenas capacidade do agente abdicante (CC, art.104, I), instrumentação por meio de escritura pública notarial (CC, art.108) e registro (CC, art.1.227, parágrafo único), cumpre, porém, anotar, que o registrador não poderá proceder ao registro do ato jurídico de renúncia abdicativa de domínio de unidade de uso exclusivo em condomínio edilício sem comprovação de prévia deliberação pela assembléia geral, com respeito à exoneração ou não do renunciante do pagamento das contribuições condominiais futuras, cuja circunstância deverá constar do 
O ilustre professor considera que a renúncia é um direito do proprietário, que independe da vontade de outros condôminos. Assim, desde que quitadas as dívidas condominiais e tributárias, é possível a renúncia ${ }^{172}$.

Em relação às dívidas vincendas, estaria exonerado o proprietário renunciante, com fundamento na regra de que o acessório segue o principal.

Germán de Castro Vítores, com apoio na lição de Hernandez Gil, ressalta que o devedor pode libertar-se da responsabilidade inerente à obrigação sempre que exercite esse direito antes de produzir-se o inadimplemento ${ }^{173}$.

Também recorre a Michon e destaca que o abandono jamais é liberatório de uma obrigação atual e exigível. Com fundamento na teoria do quase-contrato de Jouissance, afirma que para os débitos do passado houve renúncia ao direito do abandono.

Em todo caso, a renúncia não poderá prejudicar terceiros, sob pena de nulidade do ato ${ }^{174}$.

De nossa parte, consideramos que a questão deve ser vista com reservas. É certo que a renúncia à propriedade (e a qualquer direito real por extensão) é um direito reconhecido em lei.

registro para efeitos de publicidade". Diferente, contudo, é a posição do Conselho Superior da Magistratura do Estado de São Paulo, em recente julgamento: "Registro de Imóvel. Recusa de registro de escritura pública de renúncia de imóveis integrantes de condomínio edilício, só o fundamento de que, em razão do disposto no $\S 5^{o}$ do art. 12 da Lei $n^{o}$ 4.591/64, há necessidade de exibição de deliberação da Assembléia Geral, em relação à exoneração ou não do pagamento das contribuições condominiais futuras. Inexistência de amparo legal à exigência. Pressupostos do registro caracterizados, os quais não se confundem com os efeitos decorrentes da renúncia operada. Recurso provido, com a reforma da sentença do Juízo Corregedor Permanente e conseqüente improcedência da dúvida, para ingresso do título no registro imobiliário" (Processo 000.665.6/6-00).

${ }^{172}$ O Conselho Superior da Magistratura de São Paulo confirma a exigibilidade de comprovação de quitação de débitos condominiais, para fins de oneração ou alienação do imóvel. Cf. Apelação cível no 56.318-0/6, relatada pelo Desembargador Nigro Conceição.

${ }^{173}$ La obligación real en el derecho de bienes, p. 776.

${ }^{174}$ Op. cit., p. 798. Diz o autor: "en todo caso, la renuncia no puede perjudicar a terceros (tampoco el abandono liberatorio). Será nula si, a pesar de haberse realizado para liberarse de ciertas obligaciones, resulta luego que - por la desproporción entre el valor de lo renunciado y la onerosidad de aquellas - tal renúncia supone un fraude para los derechos de terceros acreedores". 
Todavia, o exercício desse direito não pode ser realizado de modo abusivo, sob pena de causar danos a terceiros ${ }^{175}$.

É o caso, por exemplo, do devedor contumaz de dívida de condomínio que resolve renunciar à propriedade quando suas dívidas superam o valor do próprio bem. Admitir-se tal renúncia nesta situação significaria prestigiar aquele que agiu de modo contrário à boa-fé, exercendo o seu direito de modo abusivo.

Nessa ordem de ideais, o renunciante sempre estará exonerado quanto às obrigações que não foram constituídas até a data da renúncia; mas pode ser compelido a responder vencidas até a renúncia.

De todo modo, a eventual existência de obrigações em aberto não pode impedir o exercício do direito de renúncia.

A renúncia pode, eventualmente, não implicar na exoneração das obrigações propter rem, as quais permanecerão exigíveis em relação ao renunciante; as vincendas, contudo, acompanham o estatuto do direito real.

\footnotetext{
175 A teoria do abuso do direito foi consagrada pelo Código Civil de 2002: "Art. 187. Também comete ato ilícito o titular de um direito que, ao exercê-lo, excede manifestamente os limites impostos pelo seu fim econômico ou social, pela boa-fé ou pelos bons costumes". Não há violação dos limites objetivos da lei. Ao contrário, o agente os obedece, mas desvia-se dos fins sociais a que se destina. Como ressalta Gustavo Tepedino, "a vasta diversidade de conceituações e critérios de aferição da abusividade deriva do fato de ser o abuso de direito uma construção de natureza essencialmente jurisprudencial, nascida da análise de problemas concretos à luz de cada sistema jurídico particular. Não obstante, sustenta-se na atualidade a noção de abuso como uma conduta que, embora lícita, mostra-se desconforme com a finalidade que o ordenamento pretende naquela circunstância fática alcançar e promover. Almeja-se com a disciplina do abuso do direito uma valoração axiológica do exercício de determinada situação jurídica subjetiva - não apenas dos direitos subjetivos, mas também dos interesses potestativos, dos poderes jurídicos, etc. - à luz dos valores consagrados no ordenamento civil-constitucional."
} 


\section{CAPÍTULO II: OUTRAS SITUAÇÕES CONSIDERADAS HÍBRIDAS}

\section{Obrigações com eficácia real}

\subsection{Considerações gerais}

Antunes Varela explica que "as obrigações gozam de eficácia real quando, sem perderem o caráter essencial de direitos a uma prestação, se transmitem, ou são oponíveis a terceiros, que adquiram direito sobre determinada coisa” ${ }^{176}$.

Para exemplificar essa espécie obrigacional os doutrinadores costumam recorrer à chamada cláusula de vigência nos contratos de locação ${ }^{177}$.

A locação é uma relação jurídica de natureza pessoal e, como tal, vincula apenas os sujeitos contratantes. Terá, entretanto, eficácia erga omnes se, no contrato, for consignada uma cláusula de vigência, estabelecendo que todas as condições locatícias serão mantidas em caso de alienação do imóvel.

É importante observar que o inquilino é protegido apenas se o contrato estiver averbado junto à matrícula do prédio averbado. Do contrário, a avença não terá nenhuma eficácia contra o adquirente, que poderá denunciar a locação a qualquer momento.

O Código Civil português contempla, no artigo $1.057^{178}$, disposição semelhante em matéria de locação. Explica Manuel Henrique Mesquita que esse direito não tem natureza real ${ }^{179}$.

\footnotetext{
${ }^{176}$ Direito das obrigações, p. 51.

177 É prevista no artigo $8^{\circ}$ da Lei $n^{\circ}$ 8.245/91: "Se o imóvel for alienado durante a locação, o adquirente poderá denunciar o contrato, com o prazo de noventa dias para a desocupação, salvo se a locação for por tempo determinado e o contrato contiver cláusula de vigência em caso de alienação e estiver averbado junto à matrícula do imóvel".

178 "O adquirente do direito com base no qual foi celebrado o contrato sucede nos direitos e obrigações o locador, sem prejuízo das regras do registo”.
} 
Outro exemplo válido para ilustrar a obrigação com eficácia real é a cláusula especial de retrovenda inserida em contrato de compra e venda de bem imóvel ${ }^{180}$.

É um pacto acessório pelo qual o vendedor reserva para si o direito de recobrar a propriedade, em certo prazo, restituindo o preço recebido e reembolsando as despesas do comprador.

O chamado direito de retrato, assim como a locação, tem natureza obrigacional e permanece válido entre as partes contratantes, ainda que a cláusula não seja averbada na matrícula do imóvel.

Todavia, o registro gera a eficácia erga omnes da obrigação, tornando o direito de retrato oponível a terceiros adquirentes do imóvel. Nesse passo, pode-se afirmar que a cláusula de retrovenda, inscrita no registro de imóveis, é uma obrigação com eficácia real.

Consiste essa modalidade de obrigação, portanto, em exceção à regra geral da relatividade dos contratos, de sorte que o novo titular do domínio deve respeitar os termos de uma avença da qual não fez parte.

\footnotetext{
${ }^{179}$ Obrigações reais e ônus reais, p. 176: "o regime jurídico da locação (...) contém normas - as respeitantes à protecção do gozo da coisa locada - de que resulta para o locatário uma posição jurídica idêntica à conferida pela titularidade de um direito real. Efectivamente, logo que se encontre 'investido' no uso ou fruição da coisa com base num contrato válido e plenamente eficaz, ao locatário não só é lícito opor a sua posição jurídica a todo aquele que ulteriormente adquira um direito com ela conflituante, como lícito lhe é outrossim defender-se autonomamente ou ex proprio iure (com ou sem a intervenção cumulativa do locador, conforme resultar das leis de processo) dos actos de terceiros que violem, pertubem ou simplesmente ameacem essa posição. A relação de gozo que se estabelece entre o locatário e a coisa locada assume, pois, a natureza de uma verdadeira relação de domínio ou soberania - isto é, de uma relação através da qual uma coisa fica directamente subordinada ao poder de uma pessoa, com exclusão de todas as demais.(...) A disciplina da locação não permite, pois, que ao direito do locatário, globalmente considerado, se reconheça, no quando dos conceitos que permitem distinguir entre relações reais e obrigacionais, natureza jurídica unitária. Trata-se de um direito de regime dualista ou misto, sendo o locatário, para determinados efeitos, titular de uma verdadeira posição de soberania e, para outros, mero contraparte de um contrato, que constitui a fonte da relação locativa e do qual este nunca se desliga”.

${ }^{180}$ A retrovenda é prevista nos artigos 505 a 508 do Código Civil. Tem a natureza de uma condição resolutiva expressa e traz como conseqüência o desfazimento da venda, com a restituição do status quo ante.
} 
Milena Donato Oliva afirma que as obrigações propter rem não se confundem com as obrigações com eficácia real ${ }^{181}$. Estas consistem numa obrigação como outra qualquer, com a peculiaridade de que seus efeitos são estendidos a terceiros, por uma opção legislativa.

Decerto, a eficácia real de uma obrigação não decorre do simples registro $^{182}$, mas depende de uma autorização expressa da lei.

Pelos mesmos motivos já expostos quando abordado o princípio da taxatividade para os direitos reais, entendemos que não é possível a criação de obrigações com eficácia real sem previsão legal.

Nesse sentido, discordamos de Luciano de Camargo Penteado que cita, como exemplo de obrigação com eficácia real, as limitações voluntárias ao exercício de empresa. Seriam, na concepção daquele autor, situações nas quais concorrentes contratam o tipo de atividade que cada um deles desenvolverá em uma determinada área fixa, levando o conteúdo do instrumento a registro imobiliário.

\footnotetext{
181 A responsabilidade do adquirente pelos encargos condominiais na propriedade horizontal, p. 83. Nas palavras da autora: "estas (obrigação com eficácia real) consistem em espécie obrigacional como outra qualquer - ao contrário das obrigações reais, cuja fonte está relacionada ao regime de uma situação jurídica subjetiva real, advindo daí diversas peculiaridades anteriormente abordadas - mas o legislador, ponderando em abstrato os interesses envolvidos na relação jurídica, optou por privilegiar a situação subjetiva de uma das partes contratantes, estatuindo que, mediante o preenchimento de certas condições, a obrigação terá eficácia real, sendo oponível a terceiros. (...) portanto, a obrigação terá eficácia real quando, embora se originando e regendo-se pelas normas aplicáveis a qualquer outra espécie obrigacional, é oponível a terceiro, desde que preenchidos determinados requisitos previstos em lei. Dessa forma, as circunstâncias em que a relação obrigacional pode ter eficácia real se encontram estabelecidas na legislação, a qual traz os pressupostos ou requisitos indispensáveis à oponibilidade do vínculo obrigacional".

182 Para Luciano de Camargo Penteado, "esta publicidade, entretanto, não altera a essência da situação jurídica decorrente da cláusula de vigência. O direito continua a ser relativo, pois a pretensão à vigência tem sujeito determinado ou determinável e, além disso, surge na contactação entre partes que declaram e comprometem suas esferas jurídicas individuais. Existem entre partes determinadas. Há um fenômeno, tipicamente eficacial, que amplia a vinculabilidade do direito. Torna-se possível a oposição do mesmo diante de qualquer terceiro, independentemente de vínculo entre o titular do direito e o terceiro. Esta força é adquirida pelo registro. (...) A pretensão à vigência, nesses casos, opera um fenômeno que amplia a eficácia do negócio para além das partes, por força da publicidade que decorre do registro. Esta oponibilidade diante de terceiros é característica das obrigações com eficácia erga omnes, que não perdem o caráter de vínculos relativos nem tampouco se confundem com as chamadas obrigações propter rem." (Direito das coisas, p. 119).
} 
Tais acordos, prossegue, são vínculos jurídicos relacionais, mas por força da específica circunstância do registro, que lhes confere publicidade, vinculariam terceiros adquirentes dos imóveis sob os quais pesam.

A todo sentir, consideramos que esses acordos não têm eficácia em relação a terceiros adquirentes, independentemente do registro dessas obrigações no registro de imóveis. Do contrário, admitir-se-ia a restrição da propriedade, impedindo a livre circulação de bens.

As obrigações com eficácia real não se confundem com o conceito de obrigação propter rem, cujo traço distintivo consiste na sua origem, isto é, na titularidade de um direito real.

A obrigação com eficácia real, por sua vez, é uma obrigação pretérita, constituída como direito pessoal, independente da vinculação ao bem. A peculiaridade consiste em que os eventuais adquirentes da coisa estarão vinculados à avença em razão da autorização legal e, ainda, da publicidade conferida pelo registro imobiliário.

\section{2. Ônus Real}

2.1. Acepções da expressão ônus e distinções necessárias

As expressões dever, obrigação e ônus jurídico são freqüentemente utilizadas de modo pouco preciso, de sorte que é importante estabelecer algumas considerações.

O dever tem um caráter genérico e compreende a necessidade de observância de determinadas regras de conduta, sob pena de incorrer em alguma sanção. Em sentido estrito, caracteriza-se pela extrapatrimonialidade e decorre de liames familiares.

A obrigação, por sua vez, consiste no vínculo jurídico que confere ao credor o direito de exigir do devedor o cumprimento de uma determinada prestação. Tem um conteúdo patrimonial. 
Orlando Gomes, com apoio na lição de Trabucchi, explica que obrigação não se confunde com a noção de ônus ${ }^{183}$. A obrigação tem como característica a imposição do sacrifício de um interesse próprio em proveito de um interesse alheio, ao passo que o ônus implica o sacrifício de um interesse próprio em relação a outro interesse próprio.

O mesmo raciocínio é destacado por Carvalho Santos que reproduz a lição do eminente processualista Carnelutti. Para o professor da Universidade de Milão o ônus pode ser considerado uma subespécie de dever ${ }^{184}$.

Interessante panorama é apresentado por Santoro Passarelli ${ }^{185}$ : o ônus é um poder condicionado; o titular, para realizar o interesse cuja tutela lhe é concedida deve não apenas exercitar esse poder, mas também desenvolver uma atividade distinta, uma certa conduta.

Essa conduta é livre, no sentido de que não se constitui no objeto de uma obrigação ou dever cuja inobservância determine uma sanção; mas é necessária para a realização do seu interesse.

Assim, como exemplo de ônus jurídico, pode-se citar o registro de um contrato de locação com cláusula de vigência como condição de eficácia do negócio em relação a terceiros adquirentes ou, ainda, o ônus probatório em matéria processual.

A sujeição, a seu turno, não se confunde com ônus nem com obrigação.

Consiste na necessidade imposta a um sujeito de suportar as conseqüências do exercício legítimo de um direito potestativo por um outro sujeito. É o que ocorre, por exemplo, na execução do patrimônio do devedor, na revogação de um mandato, na divisão do condomínio.

\footnotetext{
183 Obrigações, p. 21.

${ }^{184}$ Vale reproduzir suas palavras: "assim como o poder, na sua acepção de situação de predomínio sôbre outrem, e não na acepção de liberdade em relação aos outros, se desdobra em direito subjetivo e potestas, igualmente o dever, na acepção de ineficácia e não de um vínculo de vontade, se bifurca em sujeição e ônus. Sujeição é o estado de impossibilidade de se subtrair a um comando; ônus o de não poder valer-se do comando a não ser sob certas condições”. A posição, contudo, não é tranqüila. Carvalho Santos também cita Domenico Barbero, para quem a incoercibilidade é uma característica do ônus, em contraste com o dever. ${ }^{185}$ Op. cit., p. 181.
} 
2.2. Da noção de ônus real ${ }^{186}$

Trata-se de figura bastante complexa que, a todo sentir, não recebe um tratamento adequado pela doutrina. Não raro, autores, jurisprudência e lei recorrem à expressão ônus reais sem qualquer preocupação técnica ou científica com o seu significado.

Como observa José de Oliveira Ascensão, a designação "tem servido muitas vezes para disfarçar dificuldades de qualificação, quando referida a figuras em que se notam certos efeitos reais, mas se hesita em considerar direitos reais" ${ }^{187}$.

Em um sentido lato, os ônus reais consistem no conteúdo passivo dos direitos reais, mais precisamente naqueles casos em que há concorrência de direitos reais sobre a mesma coisa ${ }^{188}$.

Na clássica definição de Plácido e Silva, caracterizam-se os ônus reais como encargos ou obrigações que recaem diretamente sobre a propriedade, limitando sua fruição e disposição, ou servindo de garantia a outras obrigações. São, assim, fonte dos direitos reais limitados.

\footnotetext{
${ }^{186}$ Os ônus reais se distinguem dos pessoais ou jurídicos. Seriam pessoais aqueles que devem ser cumpridos pela pessoa, sem qualquer alusão ou referência a coisas. Já os ônus reais refletem diretamente na coisa, restringindo o direito de propriedade.

187 Direito civil. reais, p. 586. Também Manuel Henrique Mesquita observa que a doutrina só muito raramente, e sempre a título acidental, tem procurado delimitar o significado (Obrigações reais e ônus reais, p. 413). A jurisprudência, com frequência, utiliza as expressões ônus reais e obrigações propter rem como se sinônimas fossem.

188 Esse é o conceito defendido pelos principais doutrinadores argentinos. Confira-se Edmundo Gatti (Derechos reales - teoría general, p. 113): "El nombre de cargas o gravámenes reales, entendemos nosotros, debe reservarse para designar el aspecto pasivo de los derechos reales sobre la cosa ajena, con relación, no sólo a la cosa gravada, sino al dominio sobre ella (y por tanto, a su titular) que, en virtud de ese gravamen, resulta disminuido en su contenido normal. No se trata, pues, más que de la obligación pasiva universal, pero tan solo cuando ella es el correlato de un derecho real sobre la cosa ajena, y con referencia solamente al dueño de ella (y a sus causahabientes) y no para los terceros en general, integrantes del sujeto pasivo universal, pues la obligación pasiva de ellos nuguna modificación sufre (en la amplitud de su contenido) con el gravamen. (...) El usufructo, el uso, la habitación, la servidumbre, la hipoteca, la prenda, el anticresis, son 'derechos reales' en cabeza de sus respectivos titulares, y, en cambio, constituyen 'cargas o gravámenes reales' para el propietario de la cosa sobre la que esos derechos reales recaen”. Nesse mesmo sentido, Edgardo Valera (Op. cit., 136). Antunes Varela rechaça essa concepção: "Para que haja um ônus real, e não um simples direito real de garantia (como a hipoteca ou o privilégio creditório especial), é essencial que o titular da coisa seja realmente devedor, sujeito passivo duma obrigação, e não apenas dono ou possuidor de certa coisa cujo valor assegura o cumprimento de divida alheia” (Op. cit., p. 50).
} 
Milena Donato Oliva afirma que "os ônus reais constituem espécie peculiar de dever, contrapostos às prerrogativas asseguradas aos titulares de direitos reais, de molde a gravar o bem sobre o qual se exerce a titularidade, limitando, assim, a extensão do aproveitamento econômico (à senhoria)" ${ }^{189}$.

Assim, por exemplo, num imóvel gravado pelo direito real de usufruto, o ônus real consistiria justamente no dever que o nu-proprietário tem de respeitar o direito do usufrutuário. Da mesma forma, sobre um imóvel hipotecado recai um ônus, que é a garantia em favor do credor.

O nosso Código Civil, em diversos artigos ${ }^{190}$, faz menção aos ônus reais nesse exato sentido, isto é, dos direitos reais sobre coisa alheia que gravam o bem.

Há, contudo, uma acepção estrita para os ônus reais e que está diretamente relacionada ao objeto desta dissertação. Para José de Oliveira Ascensão: "os ônus reais são direitos inerentes cujo conteúdo essencial é o poder de exigir a entrega, única ou repetida, de coisas ou dinheiro, a quem for titular de determinado direito real de gozo" ${ }^{\prime 191}$.

O sujeito passivo, explica, é determinado propter rem: será devedor todo aquele a quem couber o gozo da coisa. Já o sujeito ativo não tem qualquer contato com a coisa, de modo que todo o proveito que o direito lhe concede resulta da titularidade de créditos.

Antunes Varela conceitua os ônus reais como "verdadeiras obrigações, no geral de prestação periódica ou reiterada, que recaem sobre o titular de determinada coisa, e que, uma vez constituídas, ficam ligadas à coisa” ${ }^{192}$.

\footnotetext{
${ }^{189}$ Milena Donato Oliva: "Exemplos de ônus reais, assim, são os deveres ambulatórios decorrentes dos direitos reais de garantia. A hipoteca, por exemplo, grava o bem, reservando-o à disposição do credor para $o$ caso de inadimplemento de uma obrigação. $O$ adquirente de um bem hipotecado não responde com o restante de seu patrimônio pelo remanescente da dívida, uma vez que o credor tem, na relação jurídica acessória de hipoteca, pretensão executória circunscrita ao bem que se encontra gravado com a hipoteca. Trata-se de um ônus real, em que somente o valor da coisa responde pela dívida" (A responsabilidade do adquirente pelos encargos condominiais na propriedade horizontal, p. 86).

${ }^{190}$ Cf. artigos 978, 1.105, 1.409, 1.474, 1.674, 1.678, 1.691 .

${ }^{191}$ Op. cit., p. 587.

192 Op. cit., p. 47.
} 
Alberto Trabucchi ${ }^{193}$ diz que, forçosamente, quem deve é a própria coisa. Luís A. Carvalho Fernandes observa que os ônus reais exerceram um papel importante no passado, tornando-se, porém, figuras relativamente raras no ordenamento ${ }^{194}$.

A mesma observação é feita por Carvalho Santos quando afirma que os ônus reais foram muito importantes na história do direito germânico. Entretanto, a partir do século XIX, sua importância foi sensivelmente reduzida, mesmo no direito alemão ${ }^{195}$.

Menezes Cordeiro ${ }^{196}$ afirma que os ônus reais colocam-se no coração da Idade Média. Naquele tempo, explica, havia a predominância da terra na vida econômica em geral, de sorte que o direito contemplava diversos benefícios de natureza econômica ditados pela forma como a sua exploração se encontrava distribuída.

Carvalho Santos cita Planitz e destaca que a origem dos ônus reais pode ser identificada nos deveres de prestação pessoal inerentes ao estado de dependência senhorial, próprios da relação existente entre senhor e vassalo ${ }^{197}$.

Para José de Oliveira Ascensão o ônus real não é um direito real, pois embora contenha a característica da inerência (o ônus adere à coisa e a determinação do sujeito passivo é determinada pela titularidade de um direito real) não está funcionalmente dirigido à atribuição da coisa ${ }^{198}$.

\footnotetext{
${ }^{193}$ Istituzioni di diritto civile, p. 493. Para Manuel Henrique Mesquita: “Estar-se-á perante exemplos desta figura jurídica, portanto, nos casos em que o proprietário de determinado prédio se encontre obrigado, nessa qualidade, ao pagamento de certa prestação, em regra periódica ou reiterada, de gêneros ou dinheiro - pagamento pelo qual responde sempre o imóvel, seja quem for o respectivo proprietário à data da execução e dispondo o credor de preferência sobre os demais credores do executado, podendo acrescer a esta responsabilidade, cumulativa ou subsidiariamente, a responsabilidade de todo o patrimônio do devedor da prestação (isto é, da pessoa a quem o prédio pertencia no período a que a prestação diz respeito”.

${ }^{194}$ Lições de direitos reais, p. 186. Cita como exemplos de ônus reais no ordenamento jurídico português, o imposto municipal sobre imóveis, a taxa de beneficiação, a taxa de exploração e conservação. ${ }^{195}$ Op. cit., p. 180.

${ }^{196}$ Direito reais, p. 363. Nas palavras do autor: "Paradigmáticos eram os direitos que os senhores feudais e os dignatários eclesiásticos tinham de perceber dos produtores directos - que nessa qualidade, se encontravam investidos em determinados direitos reais - certas prestações. No que toca aos senhores reais, essas prestações consistiam, inicialmente, em prestações de facere - por exemplo, tantos dias de trabalho anual não retribuído. Pelo contrário, o clero preferia prestações em géneros e, mais tarde, em moeda. Eram os conhecidos dízimos. Os titulares de direitos deste tipo beneficiavam, à sua maneira, da afectação da coisa: era propter rem (por causa da coisa) que usufruiam das prestações aludidas: a identidade do devedor não interessava; este encontrava-se obrigado apenas por ser titular de determinado direito real de gozo". ${ }^{197}$ Op. cit., p. 179. ${ }^{198}$ Ob. cit., p. 593.
} 
Entre nós, consideram-se exemplos de ônus reais o foro anual na enfiteuse, a renda constituída sobre imóvel.

Os impostos cujo fato gerador consistem na propriedade sobre bens imóveis (IPTU e ITR) também podem ser considerados ônus reais, na acepção mais estrita, pois guardam características que os diferenciam do regime ordinário das obrigações

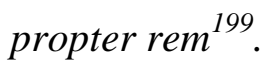

\subsection{Distinção entre ônus real e obrigação propter rem}

Tal como ocorre com as obrigações propter rem, o sujeito passivo do ônus real é o titular do direito real de gozo sobre o bem onerado. Os institutos, entretanto, não se confundem.

A responsabilidade pelo ônus real é limitada ao bem onerado, pois é a coisa que se encontra gravada; na obrigação propter rem, por sua vez, responde o devedor com todos os seus bens, ilimitadamente ${ }^{200}$.

Antunes Varela sustenta que, em se tratando de obrigação propter rem, o titular da coisa só responde pelos vínculos constituídos na vigência do seu direito, ao passo que, no ônus real, a responsabilidade é estendida àquelas obrigações constituídas anteriormente $^{201}$.

A coisa, assim, serve de garantia ao cumprimento da prestação.

\footnotetext{
${ }^{199}$ Cf. Capítulo III, item 4, da Parte III desta dissertação (p. 98).

${ }^{200}$ Nesse sentido, Trabucci (Op. cit., p. 533). Milena Donato Oliva (Op. cit., p. 85). Também para Luciano de Camargo Penteado (Direito das Coisas, p. 120).

${ }^{201}$ Confira-se o posicionamento do autor (Direito das obrigações, p. 50): "nas obrigações reais, o titular da coisa só responde, em princípio, pelos vínculos constituídos na vigência do seu direito. O condômino, que adquiriu o seu direito em 1975, por exemplo, não responde pelas despesas de conservação da coisa (comum) relativas ao ano de 1974 e 1973. Apenas é obrigado a concorrer para as despesas com a manutenção da coisa durante o período subseqüente à sua aquisição. No ônus real, porém, o titular da coisa responde mesmo pelo cumprimento de obrigações constituídas antes da aquisição do deu direito (...) o ônus real constitui, assim, uma obrigação que inere à coisa, que adere a ela, que a segue, como a sombra persegue o corpo. É uma obrigação que acompanha a coisa, como um peso (ônus) que recai sobre seu valor ativo". (...) Os ônus reais consistem em obrigações periódicas ou reiteradas e são inerentes à coisa que, em regra, serve de garantia ao cumprimento".
} 
Igual posicionamento assumido por Manuel Henrique Mesquita, para quem os ônus reais se distinguem das obrigações propter rem em dois aspectos: a ambulatoriedade da obrigação e a preferência ${ }^{202}$.

Sustenta que o credor do ônus real dispõe, em caso de execução, relativamente aos demais credores do executado, de um direito de preferência sobre a coisa onerada. Este direito de preferência, assevera, não existe nas obrigações propter rem.

José de Oliveira Ascensão critica diretamente a posição de Manuel Henrique Mesquita e não reconhece a garantia ou o privilégio do credor sobre a coisa ${ }^{203}$. Forçoso reconhecer que não há, decerto, fundamento legal para a mencionada prevalência.

Em nossa concepção, há muito mais pontos em comum do que diferenças entre as obrigações propter rem e os ônus reais. Ambos decorrem da titularidade sobre uma situação jurídica de direitos reais e consistem no conteúdo passivo dos direitos reais.

A doutrina não oferece critérios seguros para a diferenciação entre os institutos.

Considerando, ademais, que são escassos e quase inexistentes os exemplos de ônus reais em nosso ordenamento, entendemos que a expressão deve ser utilizada prioritariamente para refletir o aspecto passivo dos direitos reais sobre coisa alheia.

Evita-se, desta forma, a indesejada confusão conceitual entre os conceitos de ônus real e obrigação propter rem.

\footnotetext{
${ }^{202}$ Op. cit., p. 421. Idêntica a posição de Luís A. Carvalho Fernandes (Op. cit., p. 187).

${ }^{203}$ Op. cit., p. 590. Vale conferir as palavras do autor: "Não obstante, M. H. Mesquita retomou esta posição. Não se afasta da definição por nós dada, mas pretende que ao credor assistiria um direito de garantia sobre a coisa onerada. $O$ único elemento distintivo da obrigação propter rem seria o elemento garantia. $O$ ônus real seria assim obrigação propter rem mais garantia imobiliária. Impõe assim à lei uma conseqüência tão gravosa, que a lei de nenhum modo faz pressentir; e deixa-nos sem critério, além do nominal (uso da expressão 'ônus real', que é por demais falivel) para saber em que casos devemos considerar que a obrigação propter rem traz acopulada uma garantia, e em que casos não traz”.
} 


\title{
CAPÍTULO I: CONTRIBUIÇÕES CONDOMINIAIS
}

\section{O dever do condômino de participar do custeio do condomínio}

\author{
Estabelece o artigo 1.336, I, do Código Civil ${ }^{204}$ que é dever do
} condômino contribuir para as despesas do condomínio na proporção das suas frações ideais, salvo disposição em contrário na convenção.

A obrigação reveste-se de caráter propter rem $^{205}$, pois decorre da simples titularidade do direito real. É uma conseqüência da propriedade e tem como ratio essendi a garantia do funcionamento e da própria subsistência do condomínio.

Para José de Oliveira Ascensão ${ }^{206}$ a contribuição condominial é revestida de um caráter real, pois está diretamente relacionada ao aproveitamento e funcionalidade da coisa.

Consoante melhor doutrina ${ }^{207}$, as despesas condominiais podem ser classificadas em duas espécies.

\footnotetext{
${ }^{204}$ A disposição já existia na Lei no 4.591/64, mais precisamente em seu artigo 12 e, também, no artigo 624 do Código Civil de 1916. O parágrafo primeiro do artigo 1336 do atual Código Civil prescreve que o condômino inadimplente ficará sujeito aos juros moratórios convencionados ou, não sendo previstos, os de um por cento ao mês e multa de até dois por cento sobre o débito.

${ }^{205}$ Nesse sentido, já entendia Pontes de Miranda: "a obrigação que exsurge do dever de concorrer, em proporção, ou segundo adejcção, para as despesas, é propter rem” (Tratado de Direito Privado, vol. 12, p. 77). Ainda que, como abordado a seguir, a obrigação possa recair sobre quem não tem relação real com o bem.

${ }^{206}$ Direito civil - reais, p. 241. "É decisivo que a situação jurídica, não apenas genética mas também funcionalmente, seja elemento da solução global dum conflito, mesmo que através da criação de um modus vivendi entre os participantes. A dívida não é aqui uma dívida avulsa da situação real, como seria uma dívida de preço; é um momento do equilíbrio que se estabelece entre os direitos. Como tal, a relação da qual ela deriva é uma relação real. $O$ dever de prestar, tal como o poder de exigir, integram-se no conteúdo dos direitos reais em conflito, porque são indispensáveis para delimitar os termos exactos da afectação daquele bem, e as prestações singulares estão sujeitas a um regime real."

${ }^{207}$ Rubens Carmo Elias Filho (As despesas do condomínio edilício, p. 96/97), com apoio na lição de Norberto J. Novellino, assevera que "as despesas ordinárias constituiriam todas aquelas indispensáveis para manter o bom estado das partes e bens de uso comum do edifício, assim como suas condições de seguridade, comodidade e decoro, como também para cobrir o prêmio de seguro do edifício que o administrador tem obrigação de fazer. Já as despesas extraordinárias compreenderiam as decorrentes de inovações realizadas nas partes e bens comuns por resolução dos proprietários, objetivando lograr o melhoramento do uso, ou talvez de procurar maior renda, como seria o caso de adaptação de um espaço comum do térreo para destinar sua exploração ou aluguel como local de comércio em benefício do condomínio”.
} 
São ordinárias as despesas que representam os gastos de custeio do condomínio (salários dos empregados, o consumo de luz, água e esgoto, insumos em geral, seguro, manutenção de elevadores etc.). Extraordinárias são aquelas relacionadas à realização de obras e reparações.

Em havendo co-propriedade numa mesma unidade condominial, a doutrina e jurisprudência vêm considerando que a obrigação é solidária entre os proprietários, de modo que o condomínio, representado pelo síndico, pode exigir de qualquer um deles o pagamento da cota integral das despesas ${ }^{208}$.

Nesses casos, aquele que arcou com a cota integral pode buscar junto aos co-proprietários, em regresso, o ressarcimento do quanto pagou a mais ${ }^{209}$.

\section{A transmissão da propriedade e a contribuição condominial}

O artigo 1.345 do Código Civil determina que o adquirente de unidade responde pelos débitos do alienante ${ }^{210}$, em relação ao condomínio, inclusive quanto às multas e juros moratórios.

Desse modo, a lei atribui expressamente o caráter ambulatório à contribuição condominial, tornando o adquirente da unidade devedor das obrigações pretéritas.

\footnotetext{
${ }^{208}$ Cf. J. Nascimento Franco (Condomínio, p. 295/296): “no caso de unidade autônoma possuída por duas ou mais pessoas, há solidariedade no cumprimento das obrigações condominiais. Configura-se, no caso, uma obrigação conjunta, mas indivisível, donde poder o síndico, a seu exclusivo critério, cobrar a cota integral nas despesas a qualquer um dos co-proprietários e não necessariamente deles, em litisconsórcio passivo". Nesse mesmo sentido: "A ação de cobrança de cotas condominiais tem natureza de ação pessoal. Caracteriza-se como solidária a responsabilidade pelo seu pagamento, podendo o síndico cobrar o débito de qualquer dos co-proprietários, uma vez que a obrigação é indivisível frente ao condomínio. Ressalva-se, apenas, a quem pagar o direito de regresso previsto no art. 1.318 do novo Código Civil." (REsp n ${ }^{\circ} 500.185-$ RJ, Relatora Min. Nancy Andrighi, DJ 10/10/2005)

${ }^{209}$ Aqui cabe uma discussão a respeito da efetiva utilização dos serviços pelos co-proprietários. A matéria jamais poderia ser oposta em relação ao condomínio, pois a obrigatoriedade de contribuição não está relacionada ao uso efetivo das facilidades e serviços colocados à disposição.

${ }^{210}$ Note-se que não há qualquer distinção em relação à natureza dessas despesas, razão pela qual a responsabilidade do adquirente compreende as despesas ordinárias e extraordinárias.
} 
Trata-se, à evidência, de uma opção do legislador, cuja finalidade é garantir o equilíbrio econômico e financeiro do condomínio, que poderia ser prejudicado em caso de alienação da propriedade pelo devedor.

No direito português não há disposição semelhante, de sorte que, naquele país, o adquirente de unidade condominial responde apenas pelos débitos que surgirem na vigência de sua propriedade.

A regra já existia na Lei $n^{\circ} 4.591 / 64$, mais precisamente em seu artigo $4^{\circ}$, parágrafo único, com a seguinte redação: “a alienação ou transferência de direitos de que trata este artigo dependerá de prova de quitação das obrigações do alienante para com o respectivo condomínio" 211.

Como adverte J. Nascimento Franco ${ }^{212}$, apenas o recibo emitido pelo síndico ou administrador constitui prova eficaz da quitação. Assim, não basta eventual declaração de inexistência do débito pelo alienante, até mesmo porque as convenções entre particulares não podem ser opostas ao condomínio.

\footnotetext{
${ }^{211}$ A redação original estabelecia que "o adquirente de uma unidade responde pelos débitos do alienante, em relação ao condomínio, inclusive multas". O dispositivo, alterado pela Lei $\mathrm{n}^{\circ} 7.182 / 84$, passou a vigorar com a seguinte redação: "a alienação ou transferência de direitos de que trata este artigo dependerá de prova de quitação das obrigações do alienante para com o respectivo condomínio". Já o parágrafo segundo, do artigo $2^{\circ}$ da Lei 7.433/85 estabeleceu que: "(...), considerar-se-á prova de quitação a declaração feita pelo alienante ou seu procurador, sob as penas da lei, a ser expressamente consignada nos instrumentos de alienação ou de transferência de direitos". Assim, se o adquirente aceitasse a declaração, a venda poderia ser feita sem prova de quitação das despesas. Contudo, sem aceitação do adquirente, nenhuma venda ou promessa de venda poderia ser realizada. Essas questões, contudo, diziam respeito apenas ao alienante e ao adquirente e não atingiam o condomínio. Conforme J. Nascimento Franco: "de qualquer forma, e por se tratar de débito vinculado ao imóvel, perante o condomínio é irrelevante e considerada res inter alios aludida declaração do vendedor, motivo pelo qual, segundo assentado entendimento jurisprudencial $e$ agora, em face do art. 1.335 do CC (na verdade o autor se refere ao artigo 1.345), o adquirente responde pelas despesas não pagas pelo alienante, embora possa regressivamente voltar-se contra este reclamando o respectivo reembolso, caso a escritura de venda tenha estabelecido esse direito". A mesma orientação seguia o Superior Tribunal de Justiça (REsp nº 1654/RJ). De qualquer modo, não há mais a restrição ao registro de compra e venda sem prova da quitação.

212 Diz o autor (Ob. cit., p. 252): "somente o recibo expedido pelo síndico ou pelo administrador devidamente credenciado constitui prova eficaz de quitação, motivo pelo qual não têm os Tribunais admitido outros, tais como declaração de inexistência de débito pelo alienante da unidade autônoma devedora, visto que se trata de dívida propter rem $e$ nenhum acerto entre o vendedor e comprador interfere nas relações diretas entre o condomínio e os condôminos". Dispõe o artigo 322 do Código Civil que "quando o pagamento for em quotas periódicas, a quitação da última estabelece, até prova em contrário, a presunção de estarem solvidas as anteriores". J. Nascimento Franco sustenta que essa presunção não se estende às cotas extraordinárias, razão pela qual o síndico tem o direito de recusar o pagamento da última parcela sem o recebimento das anteriores vencidas.
} 
Cabe ressalvar que a alienação da unidade condominial não exonera o alienante da dívida.

Como visto em capítulo próprio, na obrigação propter rem não é a coisa que responde pela dívida, mas o devedor com todo o seu patrimônio ${ }^{213}$.

Vale dizer, a lei amplia o rol dos legitimados a responder pela dívida condominial, de modo que, em caso de venda da unidade, poderá ser cobrada também do adquirente.

É uma faculdade que poderá ser exercida pelo condomínio, de acordo com um juízo de conveniência e oportunidade ${ }^{214}$.

É importante consignar, ainda, que o alienante responde apenas pelos débitos que se constituíram até o momento da tradição, em função da regra do artigo 502 do Código Civil "o vendedor, salvo convenção em contrário, responde por todos os débitos que gravem a coisa até o momento da tradição”.

Todavia, permanece responsável por débitos cuja existência não era conhecida àquela época ${ }^{215}$.

\footnotetext{
${ }^{213}$ Nesse sentido, Eduardo Sócrates Castanheira Sarmento Filho (A responsabilidade pelo pagamento de cotas condominiais no regime da propriedade horizontal, p. 88) elucida que "em caso de alienação do bem, o vendedor continua vinculado e responsável pela dívida, não obstante a transmissão e seu direito”.

${ }^{214}$ Também é o entendimento de Milena Donato: “(...) ao se interpretar o art. 1.345 em conjunto com o art. 502, ambos do Código Civil, não é possível entender que a transmissão, a título singular, do direito real, altera-se o pólo passivo da relação obrigacional. Ou seja, pode-se sustentar que o legislador criou expediente processual para proteger o condomínio, possibilitando que a ação de cobrança de encargos condominiais seja proposta diretamente em face do adquirente, já que esse possui, ao menos, um imóvel para ser executado, qual seja, a unidade autônoma. Todavia, tal possibilidade conferida ao condomínio não tem o condão de alterar o devedor da obrigação propter rem. Assim sendo, mesmo que se adote o entendimento de que o art. 1.345 do Código Civil criou expediente processual pelo qual o adquirente é responsável pelos débitos do alienante em relação ao condomínio, o alienante permanece como devedor das obrigação reais nascidas na vigência de sua titularidade. Por esta razão, não há por que se excluir a possibilidade de o condomínio cobrar o seu crédito diretamente do alienante" (A responsabilidade do adquirente pelos encargos condominiais na propriedade horizontal, p. 104/105).

${ }^{215}$ Exemplifica J. Nascimento Franco (Ob. cit., p. 300) o raciocínio: "há casos em que, embora tenha o alienante pago todas as contas, surge após a venda despesa anterior desconhecida. Exemplo: salários dos empregado reconhecidos retroativamente pela Justiça do Trabalho, multas impostas ao condomínio por fato anterior à venda etc. de qualquer modo, a unidade vendida sempre responderá pelo débito, em virtude de sua natureza jurídica propter rem. Assim, o adquirente tem de pagar, mas fica com direito de regressivamente exigir reembolso do alienante." .
} 


\section{Noção de condômino: legitimidade passiva e aspectos processuais}

J. Nascimento Franco ${ }^{216}$ sustenta que a expressão "condômino", além do proprietário inscrito na matrícula do imóvel, “abrange também o promitente comprador e o cessionário de direitos relativos às unidades autônomas (art. 1.334, $\$ 2^{\circ}$, do Código Civil), bem como, por analogia, o usufrutuário, o nu-proprietário, o fiduciário, ou qualquer outro titular de direito à aquisição das unidades autônomas do edifício”.

Nesse mesmo sentido, Eduardo Sócrates Castanheira Sarmento Filho adverte que "o entendimento de que a obrigação de pagar tais cotas é do proprietário (promitente-vendedor), em nome de quem a unidade está registrada na tábula registral, decorre, principalmente, da falsa idéia de que somente o proprietário é sujeito passivo de uma obrigação propter rem. Como assevera Messineo, também os titulares de outros direitos reais, inclusive o possuidor, podem suportar o cumprimento de uma obrigação propter rem” 217.

O condômino pode atribuir a outra pessoa o dever de pagar o condomínio, como freqüentemente ocorre nos contratos de locação ${ }^{218}$. Essa cláusula, evidentemente, não pode ser oposta ao condomínio, de maneira que o locador permanece responsável pelos eventuais débitos.

Não obstante, entende-se que o locatário é parte legítima para discutir judicialmente questões relacionadas às despesas condominiais e, eventualmente, até mesmo consignar o pagamento em nome do condômino. Discute-se se ele pode ser colocado no polo passivo em ação de cobrança ${ }^{219}$.

\footnotetext{
${ }^{216}$ Op. cit., p. 288.

217 Op. cit., p. 89.

218 A Lei $\mathrm{n}^{\circ}$ 8.245/91 estabelece, em seus artigos 22 e 23, os deveres do locador (pagar as despesas extraordinárias de condomínio) e do locatário (pagar as despesas ordinárias). Essas estipulações, todavia, valem apenas entre as partes da relação locatícia e jamais poderiam ser opostas ao condomínio.

${ }^{219}$ Nesse sentido, J. Nascimento Franco: “de todo modo, no pólo passivo da ação de cobrança figura sempre o condômino e não seu inquilino, uma vez que inexiste vínculo jurídico, no tocante a despesas, entre ele e o condomínio". O Superior Tribunal de Justiça já decidiu diferente: “A ação de que dispõe o condomínio para buscar haver o valor de cotas condominiais em atraso deve ser proposta, em princípio, contra quem figure no álbum imobiliário como proprietário, promissário-comprador, cessionário ou como locatário da unidade autônoma em relação à qual exista débito em aberto. Calcada na prova a decisão das instâncias ordinárias, é de desacolher-se o apelo especial. (REsp no 30.117-1 - RJ - 4 ${ }^{\mathrm{a}}$ T. - Rel. Min. Sálvio de Figueiredo - DJU 11.09.95).
} 
Na definição do condômino responsável pelas despesas, não há maiores questionamentos naquelas hipóteses em que o proprietário concentra em suas mãos todos os poderes inerentes ao domínio. A dúvida surge quando há unidade condominial prometida à venda ${ }^{220}$.

Como estabelece o artigo 1.225, VII, do Código Civil o direito do promitente comprador do imóvel é real ${ }^{221}$, desde que devidamente registrado em Cartório.

A tendência verificada na doutrina e nos tribunais é considerar que incumbe ao compromissário comprador o pagamento das despesas de rateio com a coisa comum e, por conseguinte, é plenamente possível que figure no polo passivo da relação processual.

Há farta jurisprudência do Superior Tribunal de Justiça, no sentido de que o condomínio pode optar entre ajuizar a ação contra o proprietário (promitente vendedor) ou em face do compromissário comprador, conforme as circunstâncias do caso concreto $^{222}$.

J. Nascimento Franco considera que a posse direta do apartamento torna o compromissário comprador responsável pelas despesas de condomínio ${ }^{223}$.

\footnotetext{
${ }^{220}$ O problema é muito bem colocado por Milena Donato Oliva: "questão controversa consiste em saber se a obrigação propter rem acompanha o destino do direito real de que se origina quando nele se opera uma mutação subjetiva. Tal problema apenas surge quando, verificados os pressupostos que condicionam o nascimento das obrigações propter rem, ocorra um ato translativo do direito real antes do cumprimento desta obrigação. Com efeito, não há dissenso na doutrina acerca da vinculação do titular de uma situação jurídica real às obrigações propter rem nascidas enquanto for titular. Contudo, uma vez verificado o ato translativo de domínio, diverge-se quanto à responsabilidade pelas obrigações propter rem nascidas - mas ainda não cumpridas - antes deste ato." (Op. cit., p. 78).

${ }^{221}$ Desde que devidamente registrado, como impõe o artigo 1.417 do Código Civil. O titular do direito real pode exigir do promitente vendedor, ou de terceiros, a quem os direitos daquele forem cedidos, a outorga da escitura definitiva de compra e venda, conforme o disposto no instrumento particular; e, se houver recusa, requerer ao juiz a adjudicação do imóvel.

${ }^{222}$ Confira-se REsp n $n^{\circ}$ 728.251-SP: "Sob esse prisma, pois, esta Corte tem afirmado que a ação de cobrança de cotas condominiais pode ser proposta tanto contra o proprietário como contra o promissário-comprador ou afins, dependendo da situação de cada caso, pois o interesse primordial é o da coletividade de receber recursos para o pagamento de despesas indispensáveis e inadiáveis, podendo o credor escolher entre aqueles que tenham uma relação jurídica vinculada ao imóvel (v.g. REsp 194.481/São Paulo, de relatoria do e. Ministro Ruy Rosado Aguiar, DJ de 22/03/99). A responsabilidade, portanto, deve ser aferida de acordo com as circunstâncias do caso concreto (v.g. EREsp 138.389/MG, Rel. Min. Sálvio de Figueiredo Teixeira, DJ de 13/09/99)".

${ }^{223}$ Op. cit., p. 290. Dá, assim, grande ênfase à questão do conhecimento, pelo condomínio, da celebração do compromisso.
} 
O Superior Tribunal de Justiça, em diversas decisões, considera que a ciência, pelo condomínio, da transmissão da posse é essencial para exonerar o promitente devedor ${ }^{224}$.

\section{A preferência do crédito condominial}

Para reforçar a importância dos créditos condominiais, a jurisprudência vem reiteradamente entendendo que o crédito condominial possui preferência sobre o credor hipotecário $^{225}$.

Também é tranquilo o entendimento no sentido de que o arrematante de bem em processo judicial também responde pelos débitos em aberto do imóvel ${ }^{226}$.

Em ação de falência, já decidiu o Superior Tribunal de Justiça que os débitos condominiais não são dívida do falido, mas encargos da massa. Devem, portanto, ser pagos prioritariamente ${ }^{227}$. A questão, contudo, não é pacífica ${ }^{228}$.

O artigo $3^{\circ}$, IV, da Lei $n^{\circ} 8.009 / 90$ estabelece que a ação de cobrança de contribuições devidas em função do imóvel consiste em exceção à impenhorabilidade do chamado bem de família.

\footnotetext{
${ }^{224}$ São diversos os acórdãos segundo os quais a transferência de posse, sem a devida notificação ao condomínio, não pode ser alegada em ação de cobrança de despesas condominiais. Nesse sentido: "Obrigação propter rem. Súmula STJ - 7. Transferência de posse, por documento particular, sem intimação do condomínio, não pode ser oposta a este" (REsp 291.688/SP, Rel. Min. Ari Pargendler, DJ 04.06.2001); "CIVIL. QUOTAS DE CONDOMÍNIO. O proprietário de unidade sujeita a regime de condomínio só se exime da responsabilidade de pagar quotas respectivas, se provar que o condomínio teve ciência da venda do imóvel ou que o adquirente dele tem a posse. Recurso Especial não conhecido." (Superior Tribunal de Justiça AGRg no REsp n ${ }^{\circ}$ 734.245-São Paulo). Ainda REsp n ${ }^{\circ}$ 535.570, REsp 291.688-SP, REsp 278.386-SP, DJ 12/3/2001, e REsp 679.019-SP, DJ 20/6/2005. (STJ - REsp no 717.265 - SP - Rel. Min. Jorge Scartezzini J. 03.08.2006).

225 "Com efeito, o inadimplemento das cotas condominiais compóe débito que representa obrigação propter rem, que se constitui em função da coisa e de sua existência, para evitar-se o perecimento e a utilização, tornando-a útil à habitação.(...) A orientação mais moderna da jurisprudência desta Corte adota posição inversa ao julgado, no sentido de que o crédito condominial possui preferência sobre o do credor hipotecário." (Superior Tribunal de Justiça, REsp no 654.651-São Paulo, Relator Ministro Aldir Passarinho Junior, j. 19/4/2007). Nessa mesma linha, confira-se: REsp n ${ }^{\circ}$ 469.915/RJ, REsp no 208.896/RS, REsp n ${ }^{\circ}$ 67.701/RS, REsp n ${ }^{\circ} 592.427 / R S$, REsp n ${ }^{\circ}$ 605.056/SP, REsp n ${ }^{\circ}$ 577.547/RS, REsp n ${ }^{\circ}$ 208.896/RS, REsp n ${ }^{\circ}$ 652.505/RS e REsp no $315.963 / \mathrm{RJ}$.

${ }^{226}$ AgRg n. 781.739, REsp n. 829.312-RS, REsp n. 829.312-RS, REsp n. 659.584-SP, REsp n. 671.941-RJ, REsp n. 572.767-SC. Também o adquirente de bem em alienação fiduciária (REsp n. 827.085 - São Paulo).

${ }^{227}$ STJ - REsp 709.497 / SP

${ }^{228}$ STJ - CC n 37.178 - GO - Rel. Min. Cesar Asfor Rocha - J. 26.04.2006.
} 
Questiona-se, assim, acerca de eventual incompatibilidade com o direito à moradia, garantido pelo artigo $6^{\circ}$ da Constituição Federal, o qual não poderia ser subtraído por lei infraconstitucional.

Eros Grau, no julgamento do Recurso Extraordinário n ${ }^{\circ}$ 439.003-5, explica que a relação condominial é, tipicamente, relação de comunhão de escopo (os interesses dos contratantes são paralelos).

Nesse mesmo sentido, é remansosa a jurisprudência do Superior Tribunal de Justiça $^{229}$ ao admitir a penhorabilidade do bem de família para satisfazer dívida condominial.

\section{Condomínios irregulares e atípicos}

Como abordado alhures, as contribuições condominiais podem ser consideradas propter rem, uma vez que, por disposição legal, o condômino responde pelas contribuições em virtude da sua condição de titular de um direito real sobre a unidade.

A questão, contudo, é bastante tormentosa nos casos de condomínios irregulares ou atípicos. Trata-se de situação bastante comum; moradores de uma determinada área organizam-se na forma de uma associação, que passa a prestar os mais diversos serviços no local, tais como guarita com seguranças, ronda, jardinagem, paisagismo, limpeza, dentre outros. O condomínio, contudo, não é regularmente instituído.

Discute-se, inicialmente, se aquele que possui um imóvel em tal situação está obrigado a concorrer para as despesas geradas. Isso porque, ao contrário do que ocorre com os condomínios regulares, não existe uma norma legal que imponha o dever de contribuição.

O tema não é simples e encontra grande divergência na doutrina e, principalmente, na jurisprudência.

${ }^{229}$ Confira-se REsp n ${ }^{\text {o }} 741.601 / \mathrm{SP}$, REsp n ${ }^{\circ} 172.866$ /SP e REsp n ${ }^{\circ} 846.187 / \mathrm{SP}$. 
De um lado, há aqueles que defendem a obrigatoriedade da contribuição, sob o argumento de que o proprietário utiliza-se de serviços e, portanto, deve participar do custeio.

A outra posição sustenta, com fundamento no direito constitucional de livre associação, que ninguém pode ser compelido a participar daquilo que não deseja.

Vejamos a primeira corrente. Explica Flávia de Almeida Viveiros de Castro que a matéria deve ser encarada sob o prisma da oferta e da efetiva prestação dos serviços $^{230}$.

Destarte, com fulcro nas teorias da declaração tácita e do comportamento concludente no negócio jurídico, assevera a autora que "o sujeito desenvolve certas ações, ou assume determinado comportamento, de molde a denunciar, de forma inequívoca, no quadro das circunstâncias existentes, a vontade de vincular-se à determinada situação jurídica",231.

J. Nascimento Franco, ao comentar as decisões que negam o direito à cobrança com fundamento na inexistência de condomínio e, portanto, de obrigação de custeio, apresenta sua posição: "nosso ponto de vista diverge desta última corrente $e$ coincide com o daquelas outras, não só porque o aproveitamento de utilidades sem o respectivo pagamento constitui forma de parasitismo, que o Direito não pode respaldar, como também porque ocorre, no caso, comunhão de interesses em razão da qual decorre a obrigação de custearem os serviços de uso coletivo" ${ }^{, 32}$.

\footnotetext{
${ }^{230}$ Obrigações propter rem e condomínios atípicos, p. 72: “(...) há a aceitação tácita do morador que dos mesmos se utiliza, criando-se uma relação contratual de fato. Ou seja: a associação surge para oferta de serviços em benefício dos moradores e assim cumpre o seu papel. O gozo dos serviços pela mesma ofertados importa em aceitação tácita da oferta”.

${ }^{231}$ Prossegue o raciocínio (idem): "Assim, o proprietário de lote ou construção que não ingressa na associação, mas deixa seu lixo ensacado à porta de casa para ser retirado pelo funcionário da associação, permite a instalação de interfone em sua residência para comunicação com a portaria, usa o serviço de varredura da rua, feito por empregados pagos pela associação, usa o adesivo que identifica os carros dos moradores, requer que os seguranças contratados verifiquem as pessoas que se dirigem à sua moradia e não apresenta qualquer obstáculo ou crítica às regras de convivência do local desenvolve comportamento típico, a permitir que se infira sua tácita vinculação ao condomínio ou associação".

${ }^{232}$ Op. cit., p. 284/285.
} 
Decerto, a vedação ao enriquecimento sem causa é o principal fundamento daqueles que defendem a obrigatoriedade da contribuição dos que usufruem de serviços prestados por associação de moradores em condomínios atípicos ou irregulares ${ }^{233}$.

Expresso no artigo 884 do Código Civil ${ }^{234}$, significa que aquele que se enriquecer à custa de alguém é obrigado a restituir o indevidamente auferido.

Para Carlos Nelson Konder, essa valoração se projeta no campo da ciência do direito sob duas formas: é um princípio que atua em todos os ramos do nosso ordenamento e, também, fonte de obrigações, mais especificamente de restituir aquilo que foi indevidamente objeto de locupletamento ${ }^{235}$.

O Código Civil anterior não tratava especificamente do instituto, mas já era considerado um princípio geral do direito brasileiro e podia ser vislumbrado em diversos artigos. Em realidade, a origem remonta ao direito romano, que já previa as actiones in rem verso, que objetivavam reverter o proveito indevidamente obtido.

No sistema anterior, há várias decisões judiciais invocando o enriquecimento sem causa como embasamento para suas decisões. O Supremo Tribunal Federal já se manifestou no sentido de que consiste em garantia constitucional implícita.

A vedação ao enriquecimento sem causa também é prevista no BGB, como cláusula geral ( $\$ 812$, inciso primeiro), no Código Civil italiano de 1942 e no Código Civil Português de 1966.

\footnotetext{
${ }^{233}$ Flávia de Almeida Viveiros de Castro também recorre ao princípio da solidariedade, expresso no artigo $3^{\circ}$, I, da Constituição Federal para fundamentar sua posição. Diz que "firma-se, deste modo, o abandono da perspectiva individualista, egoísta e fonte de conflitos, para se privilegiar um comportamento solidário, responsável, firmado em benefício da sociedade como um todo. (...) conclui-se, portanto, que com base na generosa idéia da solidariedade pode-se igualmente pretender que os moradores de determinada comunidade contribuam para sua conservação e manutenção."

234 “Art. 884 - Aquele que, sem justa causa, se enriquecer à custa de outrem, será obrigado a restituir o indevidamente auferido, feita a atualização dos valores monetários."

${ }^{235}$ Enriquecimento sem causa e pagamento indevido, p. 378.
} 
Discute-se a respeito da natureza do enriquecimento, isto é, se deve ser necessariamente patrimonial ou se poderia cogitar de uma vantagem moral ${ }^{236}$.

O enriquecimento sem causa não significa, necessariamente, a ideia de um empobrecimento (diminuição de patrimônio) do titular do direito à restituição ${ }^{237}$. Também não deve existir uma causa que justifique o enriquecimento, tal como enuncia o artigo 885 do Código Civil ${ }^{238}$.

Aqueles que, por sua vez, entendem que o morador não pode ser obrigado a arcar com as contribuições exigidas pelas associações apóiam-se no artigo $5^{\circ}$, $\mathrm{XX}$, da Constituição Federal segundo o qual "ninguém poderá ser compelido a associar-se ou a permanecer associado".

Vale dizer, apenas aqueles que quiseram participar da associação é que estariam obrigados a responder pelos recursos necessários à sua manutenção, nos termos estabelecidos no seu estatuto (artigo 54, IV, do Código Civil).

A proteção constitucional conferida ao direito de associação tem natureza de garantia fundamental e, como tal, é cláusula pétrea.

Compreende o direito de ingressar numa associação e, também, o direito de não ser coagido a associar-se ou a permanecer em qualquer associação.

\footnotetext{
${ }^{236}$ É o exemplo dado pela doutrina do aluno que se aproveita de aula particular alheia. Para Carlos Nelson Konder (Ob. cit., p. 383), "o cerne da discussão sobre o valor do enriquecimento está na distinção entre dois tipos de avaliação do enriquecimento: o enriquecimento real e o enriquecimento patrimonial. $O$ enriquecimento real vincula-se ao objeto do enriquecimento. É a quantificação objetiva do valor da vantagem adquirida, o valor de uso do bem ou direito. Já o enriquecimento patrimonial está ligado ao sujeito enriquecido. E se calcula a partir do exame comparativo do seu patrimônio. É a diferença real e a hipotética, isto é, se o fato que gerou o enriquecimento não tivesse ocorrido. Para fins de quantificação da obrigação de restituir o enriquecimento sem causa, o parâmetro é o enriquecimento patrimonial."

${ }^{237}$ Na Jornada de Direito Civil, ocorrida em Brasília no mês de setembro de 2002, foi aprovada uma Proposição sobre o art. 884, a qual resultou no seguinte Enunciado: a expressão "se enriquecer à custa de outrem" do art. 884 do novo Código Civil não significa, necessariamente, que deverá haver empobrecimento. É o exemplo usado por Antunes Varela (Direito das obrigações, p. 199) daquele que utiliza cavalo alheio para ganhar uma corrida da qual o dono não participaria. Aqui também se aplica a ideia de empobrecimento real e empobrecimento patrimonial.

${ }^{238}$ Art. 885 - A restituição é devida, não só quando não tenha havido causa que justifique o enriquecimento, mas também se esta deixou de existir. A propósito, Nesse aspecto, Mario Júlio de Almeida Costa diz "quer dizer, reputa-se que o enriquecimento carece de causa, quando o direito o não aprova ou consente, porque não existe uma relação ou um facto que, de acordo com os princípios do sistema jurídico, justifique a deslocação patrimonial; sempre que aproveita, em suma, pessoa diversa daquela a quem, segundo a lei, deveria beneficiar.”
} 
Já foi mencionado que há flutuação jurisprudencial sobre a cobrança de taxa condominial por associação de moradores. O Superior Tribunal de Justiça, em particular, apresenta acórdãos antagônicos, razão pela qual o então Ministro Carlos Alberto Menezes de Direito, atualmente no Supremo Tribunal Federal, sugeriu um posicionamento definitivo da Corte.

Para o eminente Ministro Ruy Rosado de Aguiar, aquele que se recusa a contribuir, mas não deixa de usufruir dos benefícios, enriquece-se à custa do sacrifício alheio $^{239}$.

Nancy Andrigui, relatora do AgRg no Resp no 490.419-SP, observa que a obrigatoriedade da contribuição não decorre da caracterização do loteamento como aberto ou fechado, mas sim da "efetiva fruição dos serviços prestados por seus moradores".

Como se vê, a ênfase é dada à prestação de serviços, razão pela qual a questão da prova de efetiva fruição é necessária ${ }^{240}$.

239 “CONDOMÍNIO ATÍPICO. Associação de moradores. Despesas comuns. Obrigatoriedade.

O proprietário de lote integrante de gleba urbanizada, cujos moradores constituíram associação para prestação de serviços comuns, deve contribuir com o valor que corresponde ao rateio das despesas daí decorrentes, pois não é adequado continue gozando dos benefícios sociais sem a devida contraprestação. Precedentes. Recurso conhecido e provido. (...) tenho que a existência de entidade associativa, instituída pela maioria dos moradores de área urbana objeto de parcelamento do solo, pode cobrar de todos os proprietários de lotes que integram a gleba a quota correspondente ao rateio das despesas feitas em beneficio comum. A não ser assim, aquele que se recusa a contribuir e não deixa de usufruir dos benefícios estará se enriquecendo à custa do sacrifício alheio" (Superior Tribunal de Justiça - REsp no 439.661 - RJ - $4^{\text {a }}$ T. - Rel. Min. Ruy Rosado de Aguiar - j. 1.10.2002 - v.u).

"AGRAVO NO RECURSO ESPECIAL - Loteamento aberto ou fechado - Condomínio atípico - Sociedade prestadora de serviços - Despesas - Obrigatoriedade de pagamento.

O proprietário de lote integrante de loteamento aberto ou fechado, sem condomínio formalmente instituído, cujos moradores constituíram sociedade para prestação de serviços de conservação, limpeza e manutenção, deve contribuir com o valor correspondente ao rateio das despesas daí decorrentes, pois não se afigura justo nem jurídico que se beneficie dos serviços prestados e das benfeitorias realizadas sem a devida contraprestação. Precedentes."

(STJ - AgRg no REsp no 490.419 - SP - $3^{\text {a }}$ T. - Rela. Min. Nancy Andrighi - j. 10.06.2003 - v.u)

Nesse mesmo sentido, REsp n ${ }^{\circ} 439.661-R J$, REsp n ${ }^{\circ}$ 139.952-RJ, REsp no 261.892-SP, REsp n ${ }^{\circ}$ 490.419-SP, REsp no 180.838, AgRg nos Edcl no AI no 671.082-DF).

240 "Condomínio - Loteamento - Despesas com segurança e conservação - A doutrina e a jurisprudência têm entendido ser legítima a cobrança judicial de proprietário de imóvel inserido em loteamento, de despesas com segurança e conservação das vias de acesso - Todavia, na hipótese vertente, não houve a comprovação destes serviços, sendo que a prova competia à apelante, nos termos do artigo 330, inc. I, do CPC - Recurso improvido." (Tribunal de Justiça de São Paulo, Relator: Sérgio Gomes, Apelação Cível No 235.224-4/6, São Paulo, 18 de junho de 2002). 
Em posicionamento contrário, Carlos Alberto Menezes Direito dá ênfase ao aspecto associativo e sustenta que não é razoável que os próprios estatutos estabeleçam que aqueles que adquiram os lotes sejam obrigados a integrar a associação ${ }^{241}$.

O Ministro Humberto Gomes de Barros, relator do REsp n 444.931-SP, é ainda mais explícito: "A questão é simples: o embargado não participou da constituição da associação embargada. Já era proprietário do imóvel, antes mesmo de criada a associação. As deliberações desta, ainda que se revertam em prol de todos os moradores do loteamento, não podem ser impostas ao embargado. Ele tinha a faculdade - mais do que isso, o direito constitucional - de associar-se ou não. E não o fez. Assim, não pode ser atingido no rateio das despesas de manutenção do loteamento, decididas e implementadas pela associação, em nosso ordenamento jurídico há somente três fontes de obrigações: a lei, o contrato ou o débito. No caso, não atuam nenhuma dessas fontes”.

Manuel Henrique Mesquita, sustenta que as obrigações propter rem são taxativas e, portanto, existem apenas nos casos previstos em lei ${ }^{242}$. Afirma, textualmente, que não poderão se revestir desta natureza as obrigações assumidas por adquirentes dessas associações.

Em nossa concepção, a análise deve ser realizada em conformidade com o caso concreto.

\footnotetext{
${ }^{241}$ REsp 623.274. "não há dúvida, portanto, de que se trata de associação de moradores, associação sem fins lucrativos que congrega, na forma de seu estatuto, aqueles que aderirem. Isso quer dizer que esse tipo de associação não pode ser considerado um condomínio para efeitos da Lei $n^{\circ}$ 4.591/64. Como associação civil, ela exige a associação de cada associado, não sendo razoável pressupor-se, de acordo com os próprios estatutos, que automaticamente aqueles que adquirem o lote estão obrigados a se integrar, diferente, portanto, da própria estrutura do condomínio organizado sob o regime da Lei $n^{\circ} 4.591 / 64$ ”.

${ }^{242}$ Obrigações reais e ônus reais, p. 290. "(a obrigação) assumida pelos adquirentes dos lotes de terrenos compreendidos em dado empreendimento urbanístico, de realizarem determinadas obras destinadas a assegurar a harmonia estética do conjunto, ou de contribuírem, segundo certa proporção, para um fundo afectado ao pagamento de serviços (v.g., de vigilância ou de limpeza) de que todos beneficiam; etc. Obrigações desta índole só poderão produzir efeitos inter partes, não vinculando, portanto, os subadquirentes (a título originário) dos prédios em relação aos quais foram assumidas” $\mathrm{O}$ autor propõe uma solução: "com vista a conseguir efeitos tanto quanto possível aproximados de uma obrigação propter rem, poderá convencionar-se que cada proprietário fica vinculado a não alienar o direito de propriedade sem ceder conjuntamente a sua posição no contrato que constitui a fonte de obrigação. E poderá estabelecer-se mesmo uma cláusula penal para o caso de tal vinculação não ser respeitada (...). Estas cláusulas, todavia, não modificam a natureza da obrigação assumida, que deverá ser tratada, para todos os efeitos, como uma obrigação autônoma, sujeita ao regime geral das relações creditórias”.
} 
Não basta que os serviços sejam disponibilizados ao morador, sob pena de compeli-lo a participar daquilo que não quer. É necessária a comprovação de que realmente utiliza, ou se aproveita concretamente, dessas facilidades.

As posições divergentes privilegiam dois princípios igualmente importantes, a vedação ao enriquecimento sem causa e o direito de livre associação.

Todavia, acaso demonstrado que o morador efetivamente utiliza o(s) serviço(s), deverá participar do custeio, sob pena de onerar, injustamente, os demais proprietários.

O fundamento (vedação ao enriquecimento ilícito) não se coaduna com a noção de obrigação propter rem; vale dizer, não se pode compelir o morador a contribuir pela simples condição de titular de um direito real sobre imóvel situado na área de abrangência do "condomínio irregular", mas pelo fato de que efetivamente utiliza os serviços que são oferecidos.

Assim, a contribuição de proprietário exigida por associação de moradores para o custeio das despesas comuns não pode ser considerada obrigação propter rem.

Seja qual for a posição adotada, contudo, consideramos que tal obrigação jamais poderá ser transferida aos eventuais adquirentes do imóvel, por absoluta falta de embasamento legal. 


\section{CAPÍTULO II: DIREITO AMBIENTAL}

\section{Breves considerações acerca da responsabilidade civil objetiva}

É subjetiva a responsabilidade nos casos em que a culpa do agente consiste em pressuposto necessário do dano indenizável. Em outras palavras, a responsabilidade do causador do dano, ou de seu responsável legal ${ }^{243}$, somente se configura quando comprovada a conduta dolosa ou culposa.

Em determinadas situações, todavia, a lei estabelece o dever de reparação independentemente da aferição de culpa ${ }^{244}$. Trata-se da chamada responsabilidade legal ou objetiva, em que, para a caracterização do dever de indenizar, basta a verificação do nexo de causalidade entre a conduta e o dano.

O Código Civil de 2002 consolidou um processo de superação do sistema anterior, de caráter unitário, que condicionava a responsabilidade civil à aferição de culpa $^{245}$. Em realidade, já havia uma série de manifestações legislativas que contemplavam a responsabilidade objetiva, com destaque para o sistema instituído pelo Código de Defesa do Consumidor ${ }^{246}$.

São diversas as teorias que buscam justificar a responsabilidade objetiva.

\footnotetext{
${ }^{243}$ A exemplo do que determina o artigo 932 do Código Civil.

${ }^{244}$ Há situações em que a culpa é presumida pela lei; inverte-se o ônus da prova. Veja-se, por exemplo, o caso do artigo 936 do Código Civil: “o dono, ou detentor, do animal ressarcirá o dano por este causado, se não provar culpa da vítima ou força maior”. É a chamada responsabilidade objetiva imprópria. Em outras hipóteses, dispensa-se qualquer discussão a respeito da culpa. É a responsabilidade objetiva pura ou própria. ${ }^{245}$ O artigo 159 do Código Civil de 1916 sintetizava a responsabilidade civil baseada na ideia de culpa do agente. A disposição, que foi mantida pelo atual Código (artigo 186, cuja redação é semelhante, porém mais técnica), agora convive com a noção da responsabilidade sem culpa, expressa no artigo 927, § único: "Haverá obrigação de reparar o dano, independentemente de culpa, nos casos especificados em lei, ou quando a atividade normalmente desenvolvida pelo autor do dano implicar, por sua natureza, risco para os direitos de outrem”.

${ }^{246}$ A esse respeito, explica Teresa Ancona Lopez (Nexo causal e produtos potencialmente nocivos: a experiência brasileira do tabaco, p. 42) que "o Direito Brasileiro continua adotando como fundamento da responsabilidade civil a culpa (e evidentemente suas variações e presunções), porém, cada vez mais, inclui na legislação a responsabilidade objetiva, que depois da promulgação do Código de Defesa do Consumidor tomou fôlego e passou a se tornar mais conhecida e mais estudada, apesar de ainda encontrarmos resistência na jurisprudência que, vez por outra, coloca como culpa 'in vigilando', culpa 'in eligendo', culpa 'in omittendo', etc, casos típicos de responsabilidade legal, como é a responsabilidade fundada no risco”.
} 
Merece destaque a teoria do risco, segundo a qual aquele que exerce uma atividade que cria um risco de dano para terceiros deve ser obrigado a repará-lo, ainda que não seja demonstrada qualquer conduta culposa ou dolosa ${ }^{247}$. Prevalece a ideia do riscoproveito, ou seja, a atividade criadora do risco beneficia alguém que, portanto, deve ser o responsável pelos danos decorrentes.

Importante observar que o reconhecimento da responsabilidade objetiva não implica na abolição do sistema fundado na culpa. Esta segue sendo importante elemento da responsabilidade civil que, contudo, tornou-se mais complexa.

Caio Mário da Silva Pereira, após brilhante análise das teorias que justificam a responsabilidade objetiva, assevera que a extinção total do conceito de culpa provocaria um resultado antissocial e amoral, "dispensando a distinção entre lícito e ilícito, ou desatendendo à qualificação de boa ou má da conduta, uma vez que o dever de reparar tanto corre para aquele que procede na conformidade da lei quanto para aquele outro que age ao seu arrepio", 248.

Assim, hoje vigora um sistema misto, no qual a responsabilidade civil subjetiva é a regra, temperada, entretanto, com diversas hipóteses de responsabilidade sem culpa.

\footnotetext{
247 José de Aguiar Dias recorre à lição de Alvino Lima para explicar a percepção da necessidade ou o surgimento da teoria do risco (Da Responsabilidade Civil, p. 64/65): "dentro do critério da razoabilidade fundada na culpa não era possível resolver um sem-número de casos que a civilização moderna criava ou agravava, imprescindivel se tornava, para a solução do problema da responsabilidade extracontratual, agastar-se do elemento moral, da pesquisa psicológica do íntimo do agente, ou da possibilidade de previsão ou de diligência, para colocar a questão sob um ângulo até então não encarado devidamente, isto é, sob o ponto de vista exclusivo da reparação, e não inferior, subjetivo, como na imposição da pena. Os problemas da responsabilidade são tão-somente os da reparação de perdas. Os danos e a reparação não devem ser aferidos pela medida da culpabilidade, mas devem emergir do fato causador da lesão de um bem jurídico, a fim de se manterem incólumes a interesses em jogo, cujo desequilíbrio é manifesto, se ficarmos dentro dos estreitos limites de uma responsabilidade subjetiva".

${ }^{248}$ Instituições de direito civil. Vol. III, p. 366/367. Prossegue o autor dizendo que, "na necessária evolução do pensamento, entendemos que a ordem jurídica deverá fixar dois tipos de responsabilidade civil: a) a primeira fundada na culpa, caracterizada como um erro de conduta ou transgressão de uma regra predeterminada, seja de natureza contratual, seja extracontratual; b) a segunda, com a abstração da idéia de culpa, estabelecendo ex lege a obrigação de reparar o dano, desde que fique positivada a autoria de um comportamento, sem necessidade de se indagar se foi ou não contrário à predeterminação de uma norma. Uma vez apurada a existência do fato danoso, caberá indenização por parte do ofensor ou de seu preponente; mas, como se não cuida aqui da imputabilidade da conduta, somente há de ser cabida naqueles casos expressamente previstos na lei, pois é claro, se for deixado sem uma frenação conveniente, a conseqüência será o inevitável desaparecimento da primeira, com os inconvenientes acima apontados, da equiparação da conduta jurídica à antijurídica".
} 


\section{O caráter objetivo da responsabilidade civil ambiental}

Constatou-se, há muito, que as regras clássicas da responsabilidade civil fundada na culpa não seriam suficientes para enfrentar o problema ambiental ${ }^{249}$. Decerto, a responsabilidade objetiva nos casos de danos ao meio ambiente encontra previsão legal muito antes da edição do novo Código Civil.

Nesse sentido, a Lei $\mathrm{n}^{\mathrm{o}} 6.938 / 81^{250}$, que dispõe sobre a Política Nacional do Meio Ambiente, estabelece em seu artigo 14, parágrafo primeiro, que "é o poluidor obrigado, independentemente da existência de culpa, a indenizar ou reparar os danos causados ao meio ambiente e a terceiros, afetados por sua atividade”.

Quem danifica o ambiente, portanto, tem o dever de repará-lo, independentemente da licitude da atividade que exerce.

Paulo Affonso Leme Machado ressalta que a responsabilidade objetiva ambiental é uma tendência no direito comparado ${ }^{251}$. Entre nós, a questão foi constitucionalizada ${ }^{252}$.

\footnotetext{
${ }^{249}$ A esse respeito, pondera Edis Milaré (Direito do meio ambiente, p. 896) que "imaginou-se, no início da preocupação com o meio ambiente, que seria possível resolver os problemas relacionados com o dano a ele infligido nos limites estreitos da teoria da culpa. Mas, rapidamente, a doutrina, a jurisprudência e o legislador perceberam que as regras clássicas de responsabilidade, contidas na legislação civil de então, não ofereciam proteção suficiente e adequada às vitimas do dano ambiental, relegando-as, no mais das vezes, ao completo desamparo. Primeiro, pela natureza difusa deste, atingindo, via de regra, uma pluralidade de vítimas, totalmente desamparadas pelos institutos ortodoxos do Direito Processual clássico, que só ensejavam a composição do dano individualmente sofrido. Segundo, pela dificuldade de prova da culpa do agente poluidor, quase sempre coberto por aparente legalidade materializada em atos do Poder Público, como licenças e autorizações. Terceiro, porque no regime jurídico do Código Civil, então aplicável, admitiam-se as clássicas excludentes de responsabilização, como, por exemplo, caso fortuito e força maior. Daí a necessidade de busca de instrumentos legais mais eficazes, aptos a sanar a insuficiência das regras clássicas perante a novidade da abordagem jurídica do dano ambiental”.

${ }^{250} \mathrm{O}$ mesmo ocorre com a exploração de recursos minerais, que impõe ao agente a obrigação de reparar o meio ambiente degradado ${ }^{250}$. A Lei $\mathrm{n}^{\circ} 6.453 / 77$ que trata da responsabilidade civil por danos nucleares já estabelecia, em seu artigo $4^{\circ}$, a obrigação de reparação, independentemente da existência de culpa.

${ }^{251}$ Direito ambiental brasileiro, p. 336. Defende o autor o sistema da responsabilidade objetiva, segundo o qual "quem danificar o ambiente tem o dever jurídico de repará-lo. Presente, pois, o binômio dano/reparação. Não se pergunta a razão da degradação para que haja o dever de indenizar elou reparar. (...) Não interessa que tipo de obra ou atividade seja exercida pelo que degrada, pois não há necessidade de que ela apresente risco ou seja perigosa. Procura-se quem foi atingido e, se for o meio ambiente e o homem, inicia-se o processo lógico-jurídico da imputação objetiva ambiental. Só depois é que se entrará na fase do estabelecimento do nexo de causalidade entre a ação ou omissão e o dano. É contra o Direito enriquecer-se ou ter lucro à custa da degradação do meio ambiente”.

${ }^{252} \mathrm{O}$ artigo 21, XXIII, 'd', e artigo 225 da Constituição Federal.
} 
José Afonso da Silva, com apoio na lição de Rodolfo de Camargo Mancuso, ressalta que a tendência da doutrina é no sentido de não aceitar as cláusulas excludentes de responsabilidade. Em tema de interesses difusos, sustenta, o que importa é o dano produzido e a necessidade de uma integral reparação. Desse modo, a eventual demonstração, pelo causador do dano, da licitude de sua atividade não afasta o dever de reparação ${ }^{253}$.

O dano ambiental resulta de atividades que, direta ou indiretamente, causam a degradação do meio ambiente.

Edis Milaré pondera que não é toda e qualquer perturbação que é objeto de proteção pelo direito ambiental, mas apenas aquelas que produzem um resultado significativo, “cujos reflexos negativos transcendessem os padrões de suportabilidade estabelecidos" ${ }^{254}$.

A adoção do sistema da responsabilidade objetiva não afasta a necessidade do nexo de causalidade entre a atividade e o dano dela resultante. Decerto, apenas a aferição da culpa é que fica prejudicada.

Teresa Ancona Lopez ensina que "nexo causal em responsabilidade civil é o liame obrigatório entre o fato (causa) e o dano (efeito)",255.

A identificação do nexo causal em matéria ambiental é extremamente complexa, em especial naqueles casos em que há pluralidade de autores do dano ecológico $^{256}$.

\footnotetext{
${ }^{253}$ Direito ambiental constitucional: "não exonera, pois o poluidor ou degradador a prova de que sua atividade é normal e lícita, de acordo com as técnicas mais modernas. Lembra Helli Alves de Oliveira a doutrina da normalidade da causa e anormalidade do resultado, que fundamenta a reparação no caso da responsabilidade objetiva. Não libera o responsável nem mesmo a prova de que a atividade foi licenciada de acordo com o respectivo processo legal, já que as autorizações e licenças são outorgadas com a inerente ressalva de direitos de terceiros; nem quem exerce a atividade poluidora dentro dos padrões fixados, pois isso não exonera o agente, de verificar, por si mesmo, se sua atividade é ou não prejudicial, está ou não causando dano".

${ }^{254}$ Ob. cit., p. 901. Mas o autor pondera que a questão é complexa, pois em geral a lei não apresenta parâmetros que permitam uma verificação objetiva. Além disso, não está relacionada com a licitude da atividade, pois apenas a lesividade ao meio ambiente já é suficiente para provocar a tutela jurisdicional. Assim, conclui que "a aferição da anormalidade ou perda do equilíbrio se situa fundamentadamente no plano fático e não no plano normativo, segundo normas preestabelecidas".

${ }^{255}$ Ob. cit., p. 22.
} 
Patrícia Faga Iglesias $\operatorname{Lemos}^{257}$ destaca que essa dificuldade de prova tem gerado o estabelecimento de presunções de causalidade.

\section{Princípios da responsabilidade civil ambiental}

Como ressalta Edis Milaré ${ }^{258}$, os objetivos do Direito Ambiental são fundamentalmente preventivos, pois a degradação ambiental, como regra, é irreparável. Caracteriza-se, assim, o princípio da prevenção.

Como conseqüência, os legitimados para o ajuizamento da ação civil pública não estão obrigados a aguardar a consumação do dano ambiental para agir. Ao contrário, o interessado pode e deve atuar para coibir atividades que apresentem mera potencialidade de dano.

Nessa mesma linha de raciocínio colocam-se todas as práticas administrativas com o objetivo de evitar o dano ambiental, tal como o estudo prévio de impacto ambiental previsto na Constituição Federal.

\footnotetext{
${ }^{256}$ O problema é bem sintetizado por Edis Milaré (Ob. cit., p. 903), "a determinação segura do nexo causal, já que os fatos da poluição, por sua complexidade, permanecem muitas vezes camuflados não só pelo anonimato, como também pela multiplicidade de causas, das fontes e de comportamentos, seja por sua tardia consumação, seja pelas dificuldades técnicas e financeiras de sua aferição, seja, enfim pela longa distância entre a fonte emissora e o resultado lesivo, além de tantos outros fatores". Diante desse quadro, com apoio na lição de José Rubens Morado Leite, assevera que "não surpreenderá que o caminho a prosseguir conduza e justifique a instituição de um sistema assentado na inversão do ônus da prova, à semelhança do que já ocorre entre nós, em tema de relações de consumo (Lei no 8.078/90, art. 6º VIII)". Paulo Affonso Leme Machado exemplifica uma situação: "num distrito industrial ou num conglomerado de indústrias pode ser difícil apontarem-se todas as fontes poluidoras que tenham causado prejuízo. A vítima não está obrigada a processar conjuntamente os poluidores, podendo escolher aquele que lhe convier, chamar à responsabilidade, por exemplo, optando por um poluidor solvente e não pelo insolvente. Na produção do prejuízo não é preciso que um produto poluente cause por si só uma determinada doença, como por exemplo asma ou a bronquite. Hão de ser considerados os efeitos sinérgicos das emissões, concorrendo conjuntamente para a eclosão da moléstia”.

${ }^{257}$ Meio ambiente e responsabilidade civil do proprietário: análise do nexo causal, p.155. Diz a autora que " $a$ grande dificuldade de prova tem gerado o estabelecimento de presunções de causalidade. Por exemplo, se a contaminação do rio se dá por determinado tipo de poluente emitido por várias indústrias de um complexo, em princípio, todos os emissores poderiam ser considerados causadores do dano. Apenas aquele ou aqueles que demonstrarem que não causaram o dano deixarão de ser responsabilizados. São as situações em que encontramos atividades chamadas potencialmente poluidoras. Esse tema é polêmico, pois, enquanto se facilita a prova para a vítima, dificulta-se muito a prova para o pretenso responsável.".

${ }^{258}$ Op. cit., p. 898.
} 
O princípio do poluidor-pagador expressa a lógica da responsabilidade civil ambiental. Aquele que causa danos assume todos os riscos de sua atividade. Põe fim à prática inadmissível de socialização do prejuízo e da privatização do lucro.

Explica Cristiane Derani que o princípio objetiva a internalização dos custos relativos externos da deterioração ambiental ${ }^{259}$. É importante consignar que o princípio não pode ser interpretado como um estímulo à degradação ambiental, isto é, não se trata da fixação de um preço pela atividade que cause poluição. Ao contrário, o que se busca é estimular a adoção de medidas acautelatórias que impeçam a ocorrência do dano.

Em conformidade com o princípio da reparação integral, a lesão causada ao meio ambiente deve ser recuperada em sua integridade ${ }^{260}$. Para Edis Milaré ${ }^{261}$, com apoio na lição de José Rubens Morato Leite, a eventual aniquilação econômica do agente não contradiz o princípio.

\section{A reparação ambiental como obrigação propter rem}

Definidos os principais contornos da responsabilidade civil ambiental, importa analisar um aspecto que concerne diretamente ao objeto deste trabalho: o entendimento de muitos doutrinadores e da jurisprudência no sentido de que a obrigação de reparar os danos ambientais consistiria em uma obrigação propter rem ${ }^{262}$.

\footnotetext{
${ }^{259}$ Direito ambiental econômico, p. 158-159. Nas palavras da autora: "O princípio do poluidor-pagador (Verursacherprinzip) visa à internalização dos custos relativos externos de deterioração ambiental. Tal traria como conseqüência um maior cuidado em relação ao potencial poluidor da produção, na busca de uma satisfatória qualidade do meio ambiente. Pela aplicação deste princípio, impõe-se ao 'sujeito econômico' (produtor, consumidor, transportador", que nesta relação pode causar um problema ambiental, arcar com os custos da diminuição ou afastamento do dano. (...) Pelo princípio do poluidor-pagador, arca o causador da poluição com os custos necessários à diminuição, eliminação ou neutralização deste dano".

${ }^{260}$ É o que se extrai do artigo $225, \S 3^{\circ}$, da Constituição Federal e artigo $14, \S 1^{\circ}$, da Lei n ${ }^{\circ} 6.938 / 81$.

${ }^{261}$ Op. cit., p. 900. "o legislador constituinte não limitou a obrigação de reparar o dano, o que conduz à reparação integral. (...) $O$ dano deve ser reparado integralmente, o mais aproximadamente possível, pela necessidade de uma compensação ampla da lesão sofrida. (...) o agente é obrigado a reparar o dano, sob pena de redundar em impunidade. (...) Risco criado pela conduta perigosa do agente, impondo-se ao mesmo um dever-agir preventivo, como meio de se eximi da reparabilidade integral do eventual dano causado. (...) A eventual aniquilação da capacidade econômica do agente não contradiz o princípio da reparação integral".

${ }^{262}$ É a posição de Carlos Alberto de Salles (Propriedade Imobiliária e Obrigações "Propter Rem" pela Recuperação Ambiental do Solo Degradado), "a obrigação de sanar os distúrbios ambientais relacionadas à degradação do solo, como se verifica, decorre da própria condição da coisa, aderindo ao direito de propriedade, caracterizando-se, dessa forma, como propter rem”.
} 
A esse respeito, consideramos que, tecnicamente, não se trata de obrigação real; o dever de reparação é uma conseqüência da degradação ambiental e não propriamente da titularidade de um direito real ${ }^{263}$.

Em verdade, quando doutrina e jurisprudência afirmam que a obrigação de reparar o dano ambiental é propter rem enfatizam o aspecto da ambulatoriedade que usualmente caracteriza essas obrigações. Deste modo, pretendem afirmar que quem quer que seja o titular do direito real sobre o bem estará obrigado a proceder à reparação ambiental.

Não há complicações naqueles casos em que o causador do dano permanece como titular do direito real. Decerto, será obrigado a reparar o prejuízo, independentemente de culpa, em atenção ao princípio da reparação integral.

Desnecessário, em tais hipóteses, recorrer ao conceito das obrigações reais.

A resposta, contudo, é complexa nos casos em que, após a materialização do dano, opera-se a transmissão da titularidade do direito real. Nesse passo, é preciso discutir se o dever de recomposição do dano acompanha o bem e, destarte, poderia ser exigido do novo titular.

Carlos Alberto de Salles ${ }^{264}$ responde afirmativamente e defende que a obrigação acompanha o direito real transmitido, independentemente de previsão contratual acerca do assunto.

O tema vem sendo tratado pela jurisprudência.

\footnotetext{
${ }^{263}$ Como já abordado em capítulo próprio, a obrigação decorrente de um ato ilícito não é uma obrigação real. ${ }^{264}$ Confira-se: “(...) da caracterização das obrigações ambientais de recuperação do solo como obrigações propter rem extraem-se algumas importantes conseqüências que devem ser destacadas. Primeiro, a vinculação dessas obrigações a um direito real, significando dizer que o titular do domínio da coisa responde pelos gravames produzidos pelo bem de sua propriedade. Segundo, que tais obrigações transferem-se junto com a transmissão da coisa, por meio de negócios jurídicos. Vale dizer, independentemente de previsões contratuais a respeito, a obrigação de reparar o solo degradado transferese ao adquirente. Terceiro, que tais obrigações transferem-se, também, ao sucessor a título singular”.
} 
Inicialmente, o Superior Tribunal de Justiça colocava a configuração do nexo de causalidade como essencial para que se pudesse responsabilizar o adquirente de imóvel já desmatado. Assim, não seria possível imputar ao novo proprietário a obrigação de reparar o dano ${ }^{265}$.

Após a vigência do Código Civil de 2002, entretanto, a orientação do Superior Tribunal de Justiça mudou, atribuindo ao novo titular de direito real a responsabilidade pela reparação aos danos ambientais, ainda que causados em período anterior à aquisição da propriedade ${ }^{266}$.

Patrícia Iglesias pondera que "esta mudança da jurisprudência se encontra em perfeita consonância com a proteção dos direitos de terceira geração, uma vez que ao tratarmos de interesses difusos que atingem a todos indistintamente, como é o caso do meio ambiente, devemos procurar sua proteção acima de qualquer interesse exclusivamente individual" 267.

\footnotetext{
${ }^{265}$ REsp n ${ }^{\circ} 229.302$.

${ }^{266}$ Confira-se: "PROCESSUAL CIVIL. ADMINISTRATIVO. DANOS AMBIENTAIS. AÇÃO CIVIL PÚBLICA. RESPONSABILIDADE DO ADQUIRENTE. TERRAS RURAIS. RECOMPOSIÇÃO. MATAS. INCIDENTE DE UNIFORMIZAÇÃO DE JURISPRUDÊNCIA. ART. 476 DO CPC. FACULDADE DO ÓRGÃO JULGADOR.
}

1. A responsabilidade pelo dano ambiental é objetiva, ante a ratio essendi da Lei 6.938/81, que em seu art. $14, \S 1^{o}$, determina que o poluidor seja obrigado a indenizar ou reparar os danos ao meio-ambiente e, quanto ao terceiro, preceitua que a obrigação persiste, mesmo sem culpa. Precedentes do STJ:RESP 826976/PR, Relator Ministro Castro Meira, DJ de 01.09.2006; AgRg no Resp 504626/PR, Relator Ministro Francisco Falcão, DJ de 17.05.2004; RESP 263383/PR, Relator Ministro João Otávio de Noronha, DJ de 22.08.2005 e EDcl no AgRg no RESP 255170/SP, desta relatoria, DJ de 22.04.2003.

2. A obrigação de reparação dos danos ambientais é propter rem, por isso que a Lei 8.171/91 vigora para todos os proprietários rurais, ainda que não sejam eles os responsáveis por eventuais desmatamentos anteriores, máxime porque a referida norma referendou o próprio Código Florestal (Lei 4.771/65) que estabelecia uma limitação administrativa às propriedades rurais, obrigando os seus proprietários a instituírem áreas de reservas legais, de no mínimo $20 \%$ de cada propriedade, em prol do interesse coletivo. Precedente do STJ: RESP 343.741/PR, Relator Ministro Franciulli Netto, DJ de 07.10.2002." (Resp n ${ }^{\circ}$ 745.363-PR, Relator Ministro Luiz Fux, j. 20 de setembro de 2007). Em igual sentido: “(...) 5. Ao adquirir a área, o novo proprietário assume o ônus de manter a preservação, tornando-se responsável pela reposição, mesmo que não tenha contribuído para o desmatamento. Precedentes de ambas as Turmas de Direito Público. Incidência da Súmula 83/STJ." (Superior Tribunal de Justiça, Resp nº 826976-PR, Relator Ministro Carlos Meira, j. 1 de setembro de 2006) "A questão enfrentada pelo recorrente encontra-se pacificada neste Superior Tribunal de Justiça, com o mesmo entendimento do acórdão recorrido, no sentido de que o particular que adquire propriedade rural tem responsabilidade pelo seu reflorestamento, mesmo quando já a adquira devastada, ante a transferência da obrigação de conservação da área. (Superior Tribunal de Justiça, AgRg no Resp n ${ }^{\circ}$ 504626-PR, Relator Ministro Francisco Leitão, j. 17 de maio de 2004). Ainda: Resp n ${ }^{\circ}$ 282.781-PR, Resp nº 237.690-MS, Relator Ministro Paulo Medina, j. 13 de março de 2002.

${ }^{267}$ Ob. cit., p. 160. 
Bárbara Almeida de Araújo ${ }^{268}$, comentando a nova tendência do Superior Tribunal de Justiça, diz que a obrigação decorre da lei, sem necessidade de sua caracterização como propter rem.

O direito ambiental contempla, em regra, obrigações de não fazer ${ }^{269}$ (v.g. proibição de desmatamento em determinada área, preservação da vegetação ciliar) e, como tal, prescinde do conceito de obrigação propter rem. Insere-se nos limites e restrições impostos ao titular pelo estatuto do direito real.

A recomposição ambiental, em princípio, não consiste em obrigação real, pois é uma conseqüência de um dano ambiental.

Não há uma disposição legal específica, tal como ocorre com a contribuição condominial, que imponha ao adquirente de área desmatada o dever de recompor o dano.

Não obstante, acompanhamos o entendimento predominante da doutrina e jurisprudência no sentido de que é possível estabelecer tal obrigação. Inicialmente, é preciso frisar que, em matéria ambiental, prevalece o interesse da coletividade.

É a disposição clara do artigo 225 da Constituição Federal: "todos têm direito ao meio ambiente ecologicamente equilibrado, bem de uso comum do povo e essencial à sadia qualidade de vida, impondo-se ao Poder Público e à coletividade o dever de defendê-lo e preservá-lo para as presentes e futuras gerações".

\footnotetext{
${ }^{268}$ As obrigações propter rem, p. 119/120. Afirma a autora que "pode-se estar diante de uma obrigação ex lege, sem necessidade da caracterização como obrigação propter rem. Ao mesmo tempo, não se deve esquecer que, se o princípio da taxatividade não significa a restrição completa da autonomia da vontade, tendo em vista que existe possibilidade de alteração do conteúdo das obrigações reais, deve-se ser feito juízo de legitimidade constitucional sobre tais deveres jurídicos, com finalidade de não ser imposta excessiva restrição ao direito de propriedade. Finalmente, para a constituição da obrigação propter rem deverá ser observado, de alguma forma, o princípio da publicidade, sob pena de serem atingidos os interesses de terceiros, em razão do seu caráter ambulatório e de seu poder de seqüela".

${ }^{269}$ Caso a lei imponha ao titular do direito real obrigações de conteúdo positivo, pode-se falar em obrigação real.
} 
Ademais, ao contrário do que poderia ocorrer com uma obrigação qualquer, o adquirente não pode alegar surpresa com a situação, pois a degradação ambiental é identificável no momento da transmissão do direito real.

Por fim, pode-se aproveitar a concepção de Manuel Henrique Mesquita a respeito da ambulatoriedade das obrigações reais cuja prestação consiste em um fazer na própria coisa.

Decerto, partindo da premissa de que a recuperação ambiental é necessária, incumbe àquele que detém o domínio sobre a coisa realizá-la. Não seria possível compelir o alienante, pois não detém o domínio sobre a coisa.

Nessa ordem de ideias, a obrigação de reparação dos danos ambientais pode ser imposta ao titular do direito real sobre o bem, com supedâneo na disciplina constitucional de proteção ao meio ambiente. 


\section{CAPÍTULO III: IMPOSTOS SOBRE PROPRIEDADE IMOBILIÁRIA}

\section{Classificação dos tributos ${ }^{270}$. Impostos reais e pessoais}

Nas palavras de Hugo de Brito Machado, obrigação tributária "é a relação jurídica em virtude da qual o particular (sujeito passivo) tem o dever de prestar dinheiro ao Estado (sujeito ativo), ou de fazer, não fazer ou tolerar algo no interesse da arrecadação ou da fiscalização dos tributos, e o Estado tem o direito de constituir contra o particular um crédito" ${ }^{271}$.

Verificada a ocorrência do fato gerador ${ }^{272}$ previsto na lei surge, em favor do Estado, a obrigação tributária.

Os impostos são uma espécie de tributo que independem de qualquer atividade estatal específica em relação ao contribuinte ${ }^{273}$. Nesse passo, o fato gerador de um imposto está sempre vinculado ao agir (ou ao ter) do contribuinte, sem relação com uma ação do Estado. Fala-se, dessa forma, que consistem em exação não vinculada.

Dentre as diversas classificações utilizadas pela doutrina especializada, importa mencionar aquela que distingue os impostos entre reais e pessoais.

Reais são os impostos que incidem sobre uma determinada riqueza ou situação econômica, sem considerar as características específicas do contribuinte. Pessoal, por sua vez, é o imposto cuja quantidade de tributo é determinada conforme a condição econômica do sujeito passivo.

\footnotetext{
${ }^{270} \mathrm{O}$ conceito de tributo é previsto no artigo $3^{\circ}$ do Código Tributário Nacional: “tributo é toda prestação pecuniária compulsória, em moeda ou cujo valor nela se possa exprimir, que não constitua sanção de ato ilícito, instituída em lei e cobrada mediante atividade administrativa plenamente vinculada”. O sistema tributário nacional contempla cinco espécies de tributos, quais sejam, os impostos, as taxas, as contribuições de melhoria, as contribuições sociais e os empréstimos compulsórios.

${ }^{271}$ Curso de direito tributário, p. 134.

272 O conceito é dado pelo próprio Código Tributário Nacional (artigo 114): "fato gerador da obrigação principal é a situação definida em lei como necessária e suficiente à sua ocorrência".

273 Artigo 16 do Código Tributário Nacional. Como explica Hugo de Brito Machado (Op. cit., p. 296), a doutrina especializada, inspirada na lição de Geraldo Ataliba, classifica os tributos em vinculados (taxa e contribuição de melhoria) e não vinculados (impostos).
} 
Exemplo clássico é o imposto de renda, cujas alíquotas (quantidade do tributo) são variáveis segundo a renda do contribuinte.

A distinção, portanto, está diretamente relacionada ao princípio previsto no artigo 145, $\S 1^{\circ}$ da Constituição Federal, segundo o qual os impostos, sempre que possível, terão caráter pessoal e serão graduados segundo a capacidade econômica do contribuinte.

\section{Noções gerais sobre IPTU ${ }^{274}$.}

\section{Determinam a Constituição Federal e o Código Tributário Nacional que o} Imposto sobre a Propriedade Predial e Territorial Urbana - IPTU é da competência dos Municípios.

Tem função predominantemente fiscal, isto é, objetiva a arrecadação de recursos financeiros para o erário. Todavia, admite-se a função extrafiscal, em especial para adequar a utilização da propriedade à política de desenvolvimento urbano executada pelo Poder Público municipal ${ }^{275}$.

O fato gerador do IPTU é a propriedade, o domínio útil ou a posse de bem imóvel por natureza ou por acessão física ${ }^{276}$, como definido na lei civil, localizado na zona urbana do município.

\footnotetext{
274 A União Federal, por sua vez, é competente para instituir o Imposto Territorial Rural - ITR. Tem disciplina análoga ao IPTU no que diz respeito ao objeto da presente dissertação. Assume função essencialmente extrafiscal e serve como instrumento auxiliar do disciplinamento estatal da propriedade rural. Sacha Calmon Navarro Coêlho (Curso de direito tributário brasileiro, p. 310/311): "Desde a Emenda $n^{\circ} 18$ à Constituição de 1946, elegeu-se o ITR como instrumento de política fundiária, certo ainda que alguns entusiastas da tese da 'revolução do tributo' chegaram ao ponto de predicar uma reforma agrária sem expropriação, bastando o manejo correto da tributação sobre as terras".

${ }^{275}$ Com efeito, o artigo 182 da Constituição Federal oferece importante ferramenta aos Municípios para compelir os proprietários a empregarem a adequada utilização do bem. O parágrafo $4^{\circ}$ do mencionado dispositivo constitucional faculta ao Poder Público municipal, mediante lei específica para área incluída no plano diretor, exigir, nos termos da lei federal, do proprietário do solo urbano não edificado, subutilizado ou não utilizado, que promova seu adequado aproveitamento, sob pena, sucessivamente, de (a) parcelamento ou edificação compulsórios; (b) imposto sobre a propriedade predial e territorial urbana progressivo no tempo e (c) desapropriação com pagamento mediante títulos da dívida pública de emissão previamente aprovada pelo Senado Federal, com prazo de resgate de até dez anos, em parcelas anuais, iguais e sucessivas, assegurados o valor real da indenização e os juros legais. Desta forma, evita-se - ou ao menos é desestimulada - a especulação imobiliária.

${ }^{276}$ Veja-se que o Imposto Territorial Rural - ITR incide apenas sobre os imóveis por natureza. O IPTU também incide sobre as edificações.
} 
Há quem alegue que a tributação da posse não seria constitucional, pois a Constituição Federal apenas autoriza a instituição do imposto sobre a propriedade. Hugo de Brito Machado rechaça esse argumento, pois considera que a posse é um desdobramento da propriedade e, assim, estaria incluída no conceito ${ }^{277}$.

Todavia, como alerta Sacha Calmon ${ }^{278}$, não é qualquer posse que pode ser tributada. A posse do locatário, arrendatário, usuário, comodatário, dentre outras congêneres, não é passível de configurar o sujeito passivo da obrigação tributária. Em realidade, a posse prevista no Código Tributário Nacional é a da pessoa que já é ou pode vir a ser proprietária da coisa.

Ressalta Valéria C. P. Furlan que a doutrina inclui o IPTU na categoria de imposto real, em razão do aspecto material (propriedade ou domínio útil) do seu núcleo. Todavia, há autores de renome que sustentam o caráter pessoal do imposto ${ }^{279}$.

Sacha Calmon assevera que a classificação do imposto como imposto real, por grande parte dos tratadistas, denota má assimilação da ciência das finanças e, ainda, insuficiente acuidade de análise jurídica.

\footnotetext{
${ }^{277}$ Diz o autor: “(...) falando a Constituição em propriedade, naturalmente abrangeu a posse, que nada mais é que um direito inerente à propriedade. A autorização constitucional é para tributar a propriedade, e o CTN facultou à lei ordinária tomar para fato gerador do tributo a propriedade, o domínio útil ou a posse, vale dizer, o direito pleno, total que é a propriedade, ou um de seus elementos, o domínio útil, ou ainda a posse. Se a propriedade, com todos os seus elementos, está reunida em poder de uma pessoa, o tributo recai sobre ela. Se está fracionada, isto é, se ninguém é titular da propriedade plena, ou porque há enfiteuse, ou porque a posse está com pessoa diversa do proprietário, que é desconhecido, ou imune ao tributo, ou isento, então o tributo recai sobre o domínio útil, ou a posse".

278 Op cit., p. 352: "Temos para nos que o intuito do legislador da lei complementar tributária foi o mesmo do legislador latino: atingir o proprietário do bem imóvel ou o 'quase-proprietário' (o enfiteuta), ou ainda o que aparentava ser o 'proprietário' (o possuidor)”. Prossegue dizendo que "a hipótese de incidência do IPTU, portanto, harmonizados a Constituição e o Código Tributário Nacional, é o direito de propriedade sobre imóveis ou a sua posse, como a externalização do domínio ou o direito do enfiteuta sobre coisa alheia, por configurar uma 'quase-propriedade' (propriedade de fato ex vi lege)". Essa também é a posição da jurisprudência do Superior Tribunal de Justiça (REsp nº 863.396 - DF).

${ }^{279}$ A discussão é intensa. Para Valéria C. P. Furlan: "não existem, juridicamente falando, impostos reais, pois, se entendemos que a relação jurídica só pode acontecer entre duas pessoas, entre dois sujeitos - teoria kelseniana -, o imposto também, como toda relação jurídica, sempre será pessoal; até porque o imóvel não paga imposto, quem paga é o proprietário do imóvel ou o seu possuidor, no caso do IPTU (...) É dizer, se aceitássemos a classificação meramente econômica dos impostos em reais e pessoais - segundo a qual nem todos os fatos tributários poderiam ser considerados aptos para ensejar a observância do princípio da capacidade contributiva, mas apenas as hipóteses dos impostos ditos 'pessoais'-, cairia por terra a classificação jurídica dos tributos extraída do próprio texto constitucional”.
} 
Para o autor, tal classificação decorre justamente de uma confusão com o conceito de obrigação ambulatória ${ }^{280}$. A questão, em realidade, perdeu o interesse.

Havia uma enorme discussão a respeito da possibilidade de instituição do IPTU com alíquotas progressivas. O Supremo Tribunal Federal, após alguma divergência sobre a questão, adotou entendimento no sentido da inconstitucionalidade do imposto ${ }^{281}$.

Com o advento da Emenda Constitucional 29/00 estabeleceu-se, expressamente, que o IPTU pode ser progressivo em razão do valor do imóvel e adotar diferentes alíquotas em função da localização e uso do imóvel ${ }^{282}$.

\section{Sucessão da responsabilidade tributária}

A lei tributária pode submeter determinada pessoa, contribuinte ou não (mas sempre vinculada ao fato gerador da obrigação tributária), ao direito do fisco de exigir a prestação tributária.

\footnotetext{
${ }^{280}$ Op.cit., p. 351: "Sem embargo, estamos convencidos de que tal vezo enraíza-se, a par dos vícios acima expostos, em uma lembrança mal compreendida de certo tipo obrigacional que existia entre os romanos. Referimo-nos à obrigação ambulatória, em que a prestação era certus na e certus quando, mas o sujeito passivo tanto podia ser conhecido como não, por isso que a coisa ambulava com o dono, e este nem sempre era o mesmo (ambulat cum dominus). Este tipo de obrigação era comum em tributos que recaíam sobre bens imóveis, terras e edificações. Os romanos não se preocupavam com a coisa, por isso que a sua propriedade 'ambulava', em sentido legal, com o seu dono, e este era exatamente quem devia pagar o tributo, fosse lá quem fosse. A muitos pareceu que a pessoa não tinha muita importância, mas a coisa, irrelevante o seu proprietário era o que importava, por isso que o tributo incidia sobre a condição jurídica 'ser proprietário'. O imposto era pessoal. Real era o direito".

${ }^{281}$ Foi, inclusive, editada a Súmula 589, segundo a qual "é inconstitucional a fixação de adicional progressivo do imposto predial e territorial urbano em função do número de imóveis do contribuinte". Confira-se, como ilustração: "IPTU - PROGRESSIVIDADE - No sistema tributário nacional é o IPTU inequivocamente um imposto real. Sob o império da atual Constituição, não é admitida a progressividade fiscal do IPTU, quer com base exclusivamente no seu artigo 145, parágrafo primeiro, porque esse imposto tem caráter real que é incompativel com a progressividade decorrente da capacidade econômica do contribuinte, quer com arrimo na conjugação desse dispositivo constitucional (genérico) com o artigo 156, parágrafo primeiro (específico). A interpretação sistemática da Constituição conduz inequivocamente à conclusão de que o IPTU com finalidade extrafiscal a que alude o inciso II do parágrafo quarto do artigo 182 é a explicitação especificada, inclusive com limitação temporal, do IPTU com finalidade extrafiscal aludido no artigo 156, I, parágrafo primeiro. Portanto, é inconstitucional qualquer progressividade, em se tratando de IPTU, que não atenda exclusivamente ao disposto no artigo 156, parágrafo primeiro, aplicado com as limitações expressamente constantes dos parágrafos segundo e quarto do artigo 182, ambos da Constituição Federal. Recurso extraordinário conhecido e provido, declarando-se inconstitucional o subitem 2.2.3 do setor II da Tabela III da Lei no 5.641, de 22.12.1989, no Município de Belo Horizonte." (Supremo Tribunal Federal - RExtr. no 153.771-0 - MG - Plenário - Rel. Min. Moreira Alves - J. 20.11.96)

${ }^{282}$ Não obstante a alteração constitucional, há que defenda que a própria Emenda 29/00 é inconstitucional, sob o argumento de que a alíquota não progressiva do IPTU seria uma cláusula pétrea.
} 
A sucessão tributária do IPTU e ITR é expressamente prevista no artigo 130 do Código Tributário Nacional, segundo o qual o crédito tributário sub-roga-se na pessoa dos respectivos adquirentes da propriedade, domínio útil ou posse, salvo quando conste do título prova de sua quitação.

Contudo, dispõe o parágrafo único do mesmo artigo que, no caso de arrematação em hasta pública, a sub-rogação ocorre sobre o respectivo preço; vinculado ficará o respectivo preço e não o bem ${ }^{283}$. De tal sorte, o arrematante não é responsável tributário.

\section{O IPTU como ônus real}

Hugo de Brito Machado assevera que a relação tributária contempla, em regra, direitos obrigacionais; estabelece-se entre pessoas determinadas e tem como objeto prestações exigíveis de sujeitos também determinados. Há, todavia, casos em que o legislador vincula a prestação tributária a uma coisa, instituindo um verdadeiro ônus real sobre esse bem ${ }^{284}$.

Nesse passo, argumenta, os impostos cujo fato gerador consiste na propriedade, domínio útil ou posse de bens imóveis devem ser considerados ônus reais.

Com efeito, é forçoso reconhecer que tais impostos têm características que os identifica com os ônus reais, pois consistem em prestações periódicas e reiteradas que, uma vez constituídas, ficam ligadas à coisa.

Decerto, a sub-rogação do adquirente nos créditos tributários tem como finalidade vincular o bem ao cumprimento da obrigação. Frisa Hugo de Brito Machado que o adquirente não responde com todo o seu patrimônio pela dívida, mas apenas com aquele vinculado à dívida.

\footnotetext{
${ }^{283}$ Cf. Hugo de Brito Machado (Op. cit. p. 160). Em suas próprias palavras: "A não ser assim, ninguém arremataria em hasta pública, pois estaria sempre sujeito a perder o bem arrematado, não obstante tivesse pago o preço respectivo. Justifica-se o disposto no art. 130 do Código Tributário Nacional porque entre o arrematante e o anterior proprietário do bem não se estabelece relação jurídica nenhuma. A propriedade é adquirida pelo arrematante em virtude de ato judicial e não de ato negocial privado”.

${ }^{284}$ Comentários ao Código Tributário Nacional, p. 530.
} 
A mesma orientação é adotada por Milena Donato Oliva, para quem a responsabilidade do adquirente é limitada às forças do objeto do direito real; considera, entretanto, que o contribuinte à época do surgimento do fato gerador responde pelo crédito com todo o seu patrimônio ${ }^{285}$.

Para a autora, os débitos fiscais não se autonomizam, isto é, não se incorporam ao patrimônio do devedor, mas aderem à coisa. E, como tal, uma vez transmitida a titularidade do direito real, as dívidas acompanham o bem, exonerando o alienante.

Luiz Alberto Gurgel de Faria pensa de modo diverso e argumenta que o alienante não é exonerado das obrigações vencidas até a data da transmissão da titularidade. Responderia, assim, solidariamente com o adquirente ${ }^{286}$.

Em nossa concepção, o regime especial do ônus real decorre, efetivamente, da utilização da expressão sub-rogação no Código Tributário Nacional.

Como explica Caio Mário da Silva Pereira, o conceito de sub-rogação contém a ideia da substituição, isto é, uma pessoa toma o lugar de outra, assumindo sua posição e sua situação jurídica como credor ou devedor ${ }^{287}$.

Nesse passo, não consideramos possível afirmar que o alienante permaneça vinculado às prestações vencidas até o momento da transferência da titularidade do direito real, justamente porque houve a substituição da sua condição do devedor, assumida pelo novo titular.

Parece-nos coerente, ainda, que o adquirente não responda com todo o seu patrimônio pelas dívidas anteriores ao qual foi sub-rogado, dada a vinculação do débito à própria coisa. Entretanto, quanto aos débitos que surgiram na pendência de sua titularidade responde com todo os seus bens.

\footnotetext{
${ }^{285}$ A responsabilidade do adquirente pelos encargos condominiais na propriedade horizontal, p. 86.

${ }^{286}$ Código Tributário Nacional Comentado, p. 628.

${ }^{287}$ Instituições de direito civil. Vol. II, p. 144.
} 


\section{CAPÍTULO IV: OUTRAS SITUAÇÕES}

\section{Os direitos de vizinhança}

\subsection{Considerações gerais}

As relações de vizinhança, também chamadas de situações jurídicas vicinais, traduzem-se em restrições ao direito de propriedade, necessárias à convivência social.

Anota Orlando Gomes que essas limitações não são editadas para atender aos interesses dos particulares; em realidade, é o interesse coletivo de harmonizar os conflitos individuais dos proprietários vizinhos que justifica a existência da regulamentação ${ }^{288}$.

San Tiago Dantas ${ }^{289}$ é autor de magnífica obra sobre a matéria, referência na doutrina. Destaca que os direitos de vizinhança devem ser compreendidos em dois sentidos distintos.

Usualmente, explica, a doutrina enfatiza apenas o aspecto objetivo dos direitos de vizinhança, caracterizando-os como o conjunto de disposições legais relacionadas à limitação do domínio.

\footnotetext{
${ }^{288}$ Direitos reais, p. 215.

${ }^{289}$ O conflito de vizinhança e sua composição, p. 259. Vale citar as palavras do autor: "É certo que os direitos de vizinhança são um conjunto de normas, todas elas restritivas do direito de propriedade, ou antes, do poder de uso que se contém nesse direito, quando dizemos que o dono de um prédio deve suportar que para ele escorram as águas naturais do prédio superior, ou que deve conceder passagem ao vizinho sem saída para a via pública, ou (...), estamos enunciando regras limitativas do arbítrio do proprietário e tolhendo ao seu direito aquela amplitude e indeterminação de exercício que lhe são conceituais. Não é menos verdade, que, com o impor essas normas, o legislador teve em mira organizar as bases daquela comunhão natural que alguns já mostraram existir entre vizinhos, e por conseguinte não quis crear privilégios ou onus para os prédios, e sim sancionar aqueles deveres de mútua assistência que o consórcio civil impõe a todos no interesse da liberdade de cada um. O que devemos ter simultaneamente em vista, é que a expressão direitos de vizinhança pode ser tomada em dois sentidos, e que só a um deles nos referimos quando os conceituamos como 'restrições à propriedade no interesse dos particulares'. O primeiro é o sentido objetivo: chamamos direitos de vizinhança ao conjunto de normas que assim limitam o domínio. $O$ segundo é o sentido subjetivo: e aqui chamamos direito de vizinhança àquele poder que, por aplicação de alguma das normas aludidas, se concretiza em favor de um proprietário, e por ele pode ser exercido em relação ao prédio que com o seu confina”.
} 
Há, contudo, um sentido subjetivo que merece destaque e que corresponde justamente ao poder jurídico que se concretiza em favor de um proprietário, que pode ser exercido em face do proprietário ou possuidor de prédio vizinho.

Luciano de Camargo Penteado assevera que os direitos de vizinhança têm em sua origem a titularidade de uma situação jurídica do direito das coisas (propriedade ou posse) e, ainda, a possibilidade de que o exercício das faculdades sobre o imóvel de que se tem a titulação provoque reverberações em outro imóvel ${ }^{290}$.

A multiplicidade de problemas e situações conflituosas decorrentes da proximidade física de imóveis demanda uma análise essencialmente casuística para a matéria. Há, em razão dessa variedade e heterogeneidade, certa dificuldade para a construção de um sistema ou de uma teoria geral do direito de vizinhança.

Não obstante, já na sistemática do Código Civil de 1916 havia um capítulo específico para a matéria. O novo Código Civil manteve a disciplina e trata do assunto nos seus artigos 1.277 a 1.313 .

A lei civil regula, dentre outras questões, o uso anormal da propriedade, as árvores limítrofes, a passagem forçada, os limites entre prédios e o direito de construir.

\subsection{Direitos de vizinhança como obrigação propter rem}

Os direitos de vizinhança implicam, na maior parte das vezes, obrigações de natureza negativa. Estão diretamente relacionados à função social e aos limites que são inerentes ao direito de propriedade.

Há muito se entende que as faculdades e os poderes do proprietário não são absolutos e devem ser exercidos em consonância com os interesses sociais, dentre os quais se incluem os direitos dos vizinhos.

\footnotetext{
${ }^{290}$ Direito das coisas, p. 319. O autor também ressalta que o conceito jurídico de vizinhança é mais amplo do que aquele empregado na linguagem coloquial. Nesta, fala-se em vizinho como sendo o morador de paredes lindeiras, do mesmo quarteirão ou mesmo de uma região dentro de um bairro. O sentido jurídico é outro e compreende todo o espaço que possa ser atingido por uma interferência.
} 
Assim, por exemplo, o artigo 1.277 do Código Civil tem como objetivo evitar o uso anormal da propriedade, de sorte que ao vizinho prejudicado é lícito fazer cessar as interferências prejudiciais à sua segurança, ao seu sossego e à sua saúde ${ }^{291}$.

Interessante notar que a norma não é dirigida apenas àquelas atividades de cunho ilícito. Na verdade, é possível que determinada situação, ainda que não configure qualquer violação à lei ou a regulamento administrativo, seja considerada prejudicial à vizinhança e, portanto, passível de restrição.

Vale observar que o mencionado artigo legal estabelece, em seu parágrafo único, que, na avaliação de uma determinada situação que caracterize conflito de vizinhança, devem ser sopesados diversos critérios, tais como a natureza da utilização, a localização do prédio, as normas e regulamentos administrativos relacionados ao zoneamento, bem como os limites ordinários de tolerância dos moradores da vizinhança ${ }^{292}$.

Há situações, todavia, em que os chamados direitos de vizinhança impõem aos titulares de direitos reais obrigações de conteúdo positivo. Nessas hipóteses, pode-se falar em obrigações reais propriamente ditas.

Como ilustração, veja-se a determinação do artigo 1.297 do Código Civil que confere ao proprietário o direito de constranger o seu confinante a proceder com ele à demarcação ${ }^{293}$ entre os dois prédios, a aviventar rumos apagados e a renovar marcos destruídos ou arruinados, repartindo-se proporcionalmente entre os interessados as respectivas despesas.

\footnotetext{
${ }^{291}$ Luciano de Camargo Penteado (Op. cit., p. 322) sustenta que o artigo 1.277 do Código Civil é uma cláusula geral a respeito da forma de utilização da propriedade.

${ }^{292}$ São várias as teorias desenvolvidas, a exemplo da pré-ocupação. Como exemplo dessa restrição, vale citar caso julgado pelo extinto Segundo Tribunal de Alçada Civil do Estado de São Paulo, no qual se discutia a construção de um heliponto em bairro residencial, cuja instalação fora autorizada pelas autoridades administrativas: "DIREITO DE VIZINHANÇA - Uso nocivo da propriedade - Utilização de heliponto - Zona residencial - Construção aprovada pela Prefeitura Municipal e níveis de ruído compatíveis com o IPT (Instituto de Pesquisa Tecnológica) - Irrelevância - Perigo para os moradores - Existência Inadmissibilidade. Embora a construção de heliponto em bairro estritamente residencial tenha sido autorizada por ato administrativo junto à Prefeitura de São Paulo e muito embora tenha o laudo pericial constatado que o ruído existente quando do pouso e decolagem do helicóptero seja compatível com as normas técnicas pertinentes, o enfoque da questão, deve levar em consideração não apenas o sossego mas, acima de tudo, a segurança dos vizinhos." (Apelação sem Revisão nº 517.388-00/5, Juiz Relator: Gama Pellegrini, julgamento: 27 de agosto de 1998).

${ }^{293}$ A ação de demarcação de terras particulares é disciplinada nos artigos 946 do Código de Processo Civil.
} 
Trata-se, claramente, de uma obrigação propter rem, pois obriga sujeito a uma prestação de conteúdo positivo unicamente em razão de sua condição de titular de um direito real.

Disposição semelhante é prevista no artigo 1.320 do Código Civil, segundo o qual a todo tempo é lícito ao condômino exigir a divisão da coisa comum, respondendo o quinhão de cada um pela sua parte nas despesas da divisão.

Para Orlando Gomes, os direitos de vizinhança inserem-se na categoria de obrigações in rem scriptae. Aderem à coisa, não sendo determinada pessoa que as assume, mas quem estiver na posse do prédio $^{294}$.

Manuel Henrique Mesquita sustenta que as obrigações reais podem decorrer de uma violação ao estatuto de um direto real. Ilustra esse raciocínio com o caso em que o dono de um prédio constrói nele uma janela voltada sobre o prédio do vizinho, em distância inferior àquela definida em lei.

Nesse exemplo, a violação ao direito de vizinhança faz surgir, para o autor da infração, uma obrigação real e, de outro lado, atribui ao proprietário lesado o direito de exigir a tapagem da janela ${ }^{295}$.

No direito pátrio o assunto é disciplinado nos artigos 1.299 a 1.313 do Código Civil. Da interpretação sistemática desses dispositivos legais infere-se que o direito de construir, inerente ao estatuto real que decorre da propriedade, é limitado pelos direitos de vizinhança e, outrossim, pelos regulamentos administrativos.

\footnotetext{
${ }^{294}$ Direitos reais, p. 216. "As relações de vizinhança podem ser objeto de convenção entre os interessados. Quando, se regem, porém, por disposições legais, as obrigações têm, na sua quase totalidade, a natureza de obrigações reais. Persiste, no entanto, a opinião de que os correlatos direitos de vizinhança são de natureza pessoal, porque podem ser exigidos de qualquer possuidor direto. Argumenta-se, ainda, com o princípio da limitação dos direitos reais diante do qual seria absurda a categoria de direitos reais inominados ou atípicos. Concede-se afinal que alguns direitos de vizinhança tenham natureza pessoal e outros, real. Dessa dificuldade de encerrá-los em uma categoria única provém a tendência, muito difundida doutrinariamente, para considerá-los modalidades de obrigações que se caracterizam pela aderência à coisa”.

${ }^{295}$ Obrigações reais e ônus reais, p. 274.
} 
Caso ocorra violação às proibições legais ou administrativas, assiste ao lesado o direito de compelir o infrator a demolir as construções feitas, bem como a responder pelas perdas e danos.

Em relação à obrigação de fazer (demolir), forçoso reconhecer o seu caráter propter rem. Decerto, todo aquele que for o titular do direito real estará obrigado a adequar a construção aos parâmetros legais e regulamentares.

Vale dizer, o proprietário poderá ser compelido a proceder à demolição da construção, ainda que não tenha sido ele o responsável pela violação.

Todavia, é importante destacar que a eventual responsabilidade pelas perdas e danos não tem natureza propter rem; é regida pelas regras ordinárias da responsabilidade civil, não sendo admissível argumentar que a obrigação ficará incrustada no imóvel, vinculando eventuais adquirentes.

Deste modo, apenas aquele que causou o dano é que pode ser condenado a pagar a indenização.

\section{Servidões}

O legislador do Código Civil de 2002 enunciou, no artigo 1.378, o conceito de servidão, caracterizando-a como o direito real que "proporciona utilidade para o prédio dominante, e grava o prédio serviente, que pertence a diverso dono, e constitui-se mediante declaração expressa dos proprietários, ou por testamento, e subseqüente registro no Cartório de Registro de Imóveis" ${ }^{296}$.

As servidões têm sua origem no direito romano ${ }^{297}$; Servitus tem como significado escravidão, de sorte que no instituto reflete a ideia de submissão de alguma coisa ou pessoa a outrem ou a algo.

\footnotetext{
${ }^{296}$ Exige-se, como se depreende do mencionado dispositivo legal, o registro junto ao Cartório de Imóveis. Pode-se constituir uma servidão pelo testamento, por ato unilateral de vontade, por convenção ou contrato, pela usucapião e por sentença judicial em ação de divisão, para evitar o encravamento.

${ }^{297}$ Entre os romanos e, até período mais recente, havia a divisão entre servidões pessoais e servidões prediais. Note-se que o Código Civil de 1916 abordava no Livro II, Título III, Capítulo III as "Servidões Prediais”. O
} 
Caracterizam-se como direitos reais sobre coisa alheia. A relação de servidão ocorre entre dois imóveis ${ }^{298}$, independentemente de quem sejam os seus respectivos titulares.

Em outras palavras, um imóvel serve ao outro (utilizam-se as designações de prédio dominante e prédio serviente); como direito real, a servidão tem um caráter de perpetuidade. O conteúdo de uma servidão consiste em vantagem para um prédio e restrição ao outro ${ }^{299}$.

Vantagem e restrição, destarte, seriam dois aspectos correlativos das servidões. San Tiago Dantas ${ }^{300}$, com apoio na lição de Lacerda de Almeida, ressalta que as servidões não se confundem com os direitos de vizinhança.

A diferença reside na própria finalidade dos institutos, pois as servidões objetivam vantagens que ampliam o valor do prédio dominante, acrescentando à sua utilidade ou beleza, sem que isso lhe seja essencial ou indispensável.

No âmbito dos direitos vicinais, por sua vez, o direito protegido "é indispensável àquele em cujo proveito a lei o tem constituído; sem ele é impossível não já a comodidade ou o deleite do proprietário, mas a própria utilização do seu prédio pela maneira por que todos usam,301.

atual Código Civil menciona apenas "Servidões". As servidões pessoais, embora guardassem semelhanças quanto ao modo de constituição, defesa e extinção, não são propriamente servidões. São vínculos entre a coisa e a pessoa, tal como ocorre no direito real de uso e habitação.

${ }^{298}$ Evidentemente, não há relação jurídica entre imóveis, de sorte que as servidões são estabelecidas em favor dos titulares de uma situação jurídica de direito real. Fala-se, de modo pouco técnico, em relação entre os prédios, apenas de modo figurativo.

${ }_{299}$ Podem consistir em uma grande variedade de formas. Como exemplos, podemos citar as servidões de trânsito, de esgoto, aqueduto, extração de areia, passagem, não construir, dentre outras.

${ }^{300} \mathrm{O}$ conflito de vizinhança e sua composição, p. 256-257.

${ }^{301}$ Nesse mesmo sentido, explica Orlando Gomes que a servidão produz um aumento de direito para o prédio dominante, a que corresponde uma diminuição para o prédio serviente. Nos direitos de vizinhança, isso não ocorre. O exemplo mais utilizado pela doutrina para caracterizar a diferença entre os institutos é o direito de passagem forçada. Em se tratando de prédio encravado, o proprietário tem o direito de exigi-la, com fundamento na necessidade de tornar útil sua propriedade. Já a servidão de passagem pode ser estabelecida apenas como modo de ampliar o acesso a um prédio, com vistas à comodidade e facilidade. Não importa, aqui, o encravamento. Oliveira Ascensão (Direito civil - reais, p. 249) explica que a servidão representa sempre uma restrição anormal dum direito sobre um imóvel, estabelecida pela via convencional. As restrições legais de vizinhança, por sua vez, traduzem o regime normal desses direitos. 
A origem dos institutos também é distinta, vez que os direitos de vizinhança nascem com o direito de propriedade e derivam diretamente da lei ${ }^{302}$. As servidões, por sua vez, decorrem da vontade das partes e são formadas com o registro do título constitutivo no registro de imóvel.

As chamadas servidões positivas ${ }^{303}$ implicam em permissão de prática de atos sobre o prédio serviente. É o caso da servidão de passagem. Negativas são as servidões que implicam abstenção ao titular do prédio serviente. É o caso da proibição de construir.

Eventualmente, as servidões podem implicar obrigações propter rem. Em regra ${ }^{304}$, as obras necessárias à conservação e uso de uma servidão incumbem ao dono do prédio dominante.

Todavia, é possível que o título constitutivo da servidão imponha ao dono do prédio serviente tal dever.

Nesses casos, trata-se de típica obrigação real, eis que vinculará o titular do direito real a uma prestação de conteúdo positivo (obras necessárias à conservação e uso da servidão) pela simples condição de titular de um direito real.

\section{Usufruto}

\subsection{Considerações gerais}

O usufruto é um direito real, de natureza temporária, que assegura ao titular o direito de utilizar e fruir coisa alheia ${ }^{305}$.

\footnotetext{
${ }^{302}$ Há quem designe os direitos de vizinhança como servidões legais. Fala-se, também, em servidões administrativas naqueles casos em que há restrição ao exercício amplo da propriedade em benefício do interesse público. Como exemplo, cite-se a passagem de cabos de energia, tubulação de água e esgoto, proibição de edificação a determinada altura em região de aeroportos etc. Não há, aqui, elemento essencial às servidões do direito civil, que é a relação entre o prédio dominante e o serviente.

${ }^{303}$ Dentre as classificações, fala-se em servidões rústicas e urbanas, conforme a utilidade proporcionada. São urbanas aquelas constituídas em favor de um prédio edificado, e rústicas são as que se ligam ao solo sem relação necessária com os edifícios que estão na superfície. Servidões aparentes são aquelas que se materializam e são perceptíveis (ex. aqueduto). Não aparentes são aquelas imperceptíveis aos sentidos, que não se manifestam em atos concretos (ex. servidão de não construir).

${ }^{304}$ Artigo 1.381 do Código Civil.
} 
O usufrutuário, com efeito, não é o dono, mas reúne os atributos do uso, da fruição, da administração e da posse. O proprietário permanece com a chamada "nua propriedade", a qual consiste no domínio despojado do jus utendi e jus fruendi.

Tem como função predominante assegurar um meio de subsistência ao usufrutuário, restringindo-se usualmente às relações familiares ${ }^{306}$.

É voluntário, quando constituído mediante contrato ou pelo testamento. O usufruto também pode ser estabelecido pela lei, independentemente de ato de vontade do beneficiário. É o caso do usufruto conferido aos pais sobre os bens dos filhos menores, tal como estipula o artigo 1.689, I, do Código Civil.

Não se confunde com a locação e o comodato, que têm natureza pessoal e, portanto, só produzem efeitos entre as partes contratantes. O usufruto é um direito real e, dessa maneira, tem eficácia erga omnes.

Também se distingue da enfiteuse, prevista no Código Civil de $1916^{307}$. Decerto, os direitos do enfiteuta são mais amplos, pois é possível ao titular até mesmo alienar a coisa. Além disso, a enfiteuse é perpétua e onerosa, ao passo que o usufruto, em regra, é gratuito. Por fim, a enfiteuse incide somente sobre bens imóveis; o usufruto pode ter como objeto bens móveis ou imóveis.

3.2. Os deveres e obrigações impostos ao usufrutuário

Como observa Germán de Castro Vítores, a adequação dos interesses dos sujeitos implicados na relação usufrutuária exige do legislador a previsão de uma série de obrigações, sem prejuízo de eventual regulamentação convencional adequada ao caso concreto $^{308}$.

\footnotetext{
${ }^{305}$ É previsto nos artigos 1.390 a 1.411 do Código Civil.

${ }^{306}$ Cf. Orlando Gomes, Direitos Reais, p. 334. O autor ressalta que é reduzida a sua importância econômica, pois constitui entrave à circulação de riquezas.

${ }^{307}$ Essa espécie de direito real não foi reproduzida pelo novo Código Civil, que expressamente proibiu a constituição de novas enfiteuses e subenfiteuses (artigo 2.038).

${ }^{308}$ La obligación real en el derecho de bienes, p. 646. Exemplifica o autor que podem ser inseridas no título constitutivo do usufruto determinadas garantias, destinadas a assegurar que os bens objeto do direito real
} 
O autor analisa diversas espécies de usufruto reguladas pelo Código Civil espanhol e observa que a regulação do instituto constitui um interessante cenário para o estudo das obrigações reais ${ }^{309}$.

Essa disciplina minuciosa objetiva prevenir um eventual conflito entre os dois titulares dos direitos reais, isto é, o usufrutuário e o nu proprietário. Nesse passo, a lei estipula algumas obrigações, as quais têm manifestamente natureza propter rem.

É a função precípua da obrigação real enunciada por Hassen Aberkane, qual seja, a composição de interesses de titulares de direitos potencialmente rivais.

Destarte, o Código Civil impõe obrigações ao usufrutuário, relacionadas à conservação da coisa e o dever de responder pelas prestações e tributos decorrentes da posse ou do rendimento da coisa usufruída ${ }^{310}$.

Exige-se do usufrutuário que conserve as coisas que lhe foram entregues em usufruto com o cuidado que se espera do homem médio ${ }^{311}$. Deverá, assim, responder pelas despesas ordinárias de conservação. Da mesma forma, está obrigado a avisar ao proprietário acerca de qualquer lesão produzida contra a posse da coisa ou em relação aos seus direitos.

Germán de Castro Vítores realiza interessante análise acerca da possibilidade de renúncia ao usufruto, mais precisamente nos casos em que a coisa necessita de reparações ordinárias no momento da renúncia. Explica que há duas posições distintas.

serão devidamente restituídos ao nu proprietário. Essas garantias são obrigações propter rem e caracterizam interessante exemplo da atuação do princípio da autonomia privada na estruturação dos direitos reais.

${ }^{309}$ Idem, p. 652.

${ }^{310}$ As obrigações estão estabelecidas nos artigos 1.400 a 1.409 do Código Civil.

${ }^{311}$ Cf. Germán de Castro Vítores (idem, p. 648): “(...) la obligación de cuidar las cosas dadas en usufructo como un buen padre de familia (art. 497 CC) que se proyecta y concreta en los diversos deberes del usufructuario, y actúa como principio y criterio informador de su actuación en todo aquello que no reciba específica ordenación legal". 
A primeira, adotada pelo Código Civil de Portugal, enuncia que o usufrutuário pode eximir-se das reparações ordinárias ou despesas a que é obrigado, renunciando ao usufruto. A renúncia, assim, produziria um efeito liberatório.

A tendência, contudo, seria pela impossibilidade de liberação da obrigação em razão da renúncia. Vale dizer, o usufrutuário não estaria impedido de renunciar ao direito real, mas tem o dever de restituir a atender às reparações ordinárias atuais. 


\section{CONCLUSÕES}

Após analisar as diversas hipóteses identificadas como obrigações reais, é possível compreender a dificuldade no trato do instituto.

Dos principais casos estudados verifica-se, como única afinidade, a circunstância de que as obrigações propter rem têm sua origem na titularidade de uma situação jurídica do direito das coisas.

Infere-se, ainda que de modo tênue, que essas obrigações são em geral impostas pela lei como modo de permitir ou facilitar a convivência de direitos reais conflitantes.

O regime jurídico das obrigações reais, justamente pela heterogeneidade de suas manifestações, não obedece a um regime único. Em outras palavras, as características usualmente atribuídas às obrigações propter rem não estão sempre presentes.

As obrigações reais obedecem ao princípio da taxatividade e, portanto, são previstas em lei. É possível notar uma mitigação do princípio em matéria condominial, em especial no estabelecimento de normas de convivência previstas na convenção e no regulamento interno.

Esse regramento evidencia a incidência da autonomia da vontade na estruturação do direito real. Admite-se, assim, a criação de obrigações com natureza propter rem, as quais vinculam os atuais e futuros titulares das unidades condominiais.

É certo, porém, que o conteúdo dessas obrigações estará sempre sujeito a um juízo de legitimidade, em conformidade com os interesses envolvidos. 
Ao contrário do que costuma asseverar a doutrina nacional, consideramos que não é possível afirmar que toda obrigação propter rem seja dotada de ambulatoriedade, isto é, que sempre acompanha a coisa.

Na verdade, o que identifica a obrigação real é a sua origem na titularidade de uma situação jurídica do direito das coisas; isso não significa que, necessariamente, a obrigação permanecerá vinculada ou aderida à coisa.

Vale dizer, a ambulatoriedade, embora usualmente presente nas obrigações propter rem, não é uma característica essencial do instituto. Veja-se, por ilustração, a obrigação do condômino de contribuir com as despesas condominiais.

Ora, não houvesse a determinação do artigo 1.345 do Código Civil, seria descabido defender a responsabilidade do adquirente pelos débitos condominiais vencidos - e não pagos - antes da transmissão. A obrigação é transmitida em razão de expressa vontade do legislador, que entendeu por bem prestigiar o crédito em prol da sobrevivência do condomínio.

Em Portugal, contudo, não existe regra semelhante, de modo que o adquirente apenas responde pelos débitos que surgiram na vigência de sua titularidade sobre o bem.

Situação diferente ocorre, por exemplo, nos casos de débitos relacionados aos serviços de energia e água. Ainda que se admita a natureza propter rem dessas despesas - pois o titular torna-se obrigado ao pagamento pelos serviços prestados ou disponibilizados - não se pode concluir que as dívidas vencidas sejam transmitidas ao novo adquirente, uma vez que inexiste determinação legal nesse sentido.

Veja-se que a prestação que consiste no objeto da obrigação, em algumas situações, está diretamente relacionada à fruição pelo titular do direito real, não sendo razoável imputar ao adquirente a responsabilidade pelos débitos vencidos em todos os casos. 
A renúncia ao direito real não implica, necessariamente, a exoneração das obrigações pendentes.

Como abordado em capítulo próprio, entendemos que é justo e compreensível que o titular de um direito real exerça um juízo de valor a respeito da conveniência, ou não, da manutenção do seu direito.

Tem, portanto, o direito de analisar se os benefícios que aufere com a titularidade da coisa compensam os custos que decorrem de uma obrigação propter rem ou dos ônus que recaem sobre o bem.

Entretanto, no que diz respeito às obrigações propter rem, a renúncia gera efeito apenas em relação àquelas prestações que ainda não se tornaram exigíveis; vale dizer, não é possível a exoneração de obrigações que já se autonomizaram na vigência do seu direito.

As obrigações com eficácia real não se confundem com as obrigações propter rem. São obrigações comuns, com a peculiaridade de que seus efeitos atingem terceiros (erga omnes), em razão de autorização legal e do registro imobiliário. É o caso da cláusula de vigência em contrato de locação e do direito de retrato na compra e venda.

A expressão ônus real, por sua vez, deve ser compreendida como o aspecto passivo que decorre da concorrência de diferentes direitos reais sobre a mesma coisa (direitos reais sobre coisa alheia).

Há uma acepção mais estrita, que remete aos ônus reais originados na Idade Média. Essa figura, cada vez mais rara, apenas encontra alguma importância no que diz respeito aos impostos cujo fato gerador é a propriedade sobre bens imóveis.

Quanto aos chamados condomínios irregulares, discute-se a respeito da obrigatoriedade da contribuição. A divergência coloca em conflito dois princípios igualmente importantes: a vedação ao enriquecimento ilícito e a liberdade de associação. 
De nossa parte, entendemos que o sujeito que efetivamente utiliza os serviços deve ser obrigado a arcar com as contribuições cobradas pelas associações de moradores. Esse dever, entretanto, não tem natureza propter rem, pois não decorre da titularidade do direito real, mas da efetiva utilização dos serviços prestados.

E tais débitos, é importante ressaltar, não aderem à coisa e jamais poderiam ser transferidos ao novo adquirente do bem, por absoluta falta de amparo legal.

A reparação pelos danos ambientais pode ser imposta ao adquirente de área já desmatada; entretanto, não consideramos que essa obrigação seja revestida do caráter propter rem, pois não é a consequiência de um ato ilícito.

Sem prejuízo, consideramos que o novo proprietário pode ser compelido a recuperar o local sob outros fundamentos, notadamente a garantia ao meio ambiente saudável.

A proposta deste trabalho não consistia na superação de conceitos e problemas tão intricados como obrigações propter rem e ônus reais. Essa tarefa, no meu entendimento, não é possível, já que pela diversidade da matéria não existe um regime uniforme.

Talvez o mérito resida justamente na simplificação do conceito, estabelecendo como propter rem (em razão da coisa) aquelas obrigações originadas da titularidade de uma situação jurídica de direito real.

O regime e as características dessas obrigações deverão, contudo, ser analisados caso a caso. 


\section{BIBLIOGRAFIA}

ABERKANE, Hassen. Essai d'une théorie générale de l'obligation propter rem en detroit positif français. Paris: Librairie générale de droit et de jurisprudence, 1957.

ARAÚJO, Bárbara Almeida de. As obrigações propter rem. Obrigações: estudos na perspectiva civil-constitucional. Coord. Gustavo Tepedino, Rio de Janeiro: Renovar, 2005.

AZEVEDO, Antonio Junqueira de. Restrições convencionais de loteamento. Estudos e pareceres de direito privado. São Paulo: Saraiva, 2004.

BALBI, Giovanni, Le obbligazioni propter rem. Torino: G. Giappochelli, 1959.

BESSONE, Darcy. Direito reais. São Paulo: Saraiva, 1988.

BETTI, Emilio. Teoria geral das obrigações. Campinas: Bookseller, 2006.

BEVILAQUA, Clóvis. Direito das coisas. Rio de Janeiro: Forense, 1956.

CÁNFORA, Roxana B. Obligaciones reales. Rosário: Editorial Juris, 1996.

CASTRO, Flávia de Almeida Viveiro de. Obrigações propter rem e condomínios atípicos. Revista dos Tribunais. Vol. 799, p. 64-76, São Paulo, 2002.

CHAVES, Antônio. Lições de direito civil - direito das coisas. São Paulo: Revista dos Tribunais, 1974.

COÊLHO, Sacha Calmon Navarro. Curso de direito tributário brasileiro. $5^{\text {a }}$ ed., Rio de Janeiro: Editora Forense, 2000. 
COMPARATO, Fábio Konder. Direitos e deveres fundamentais em matéria de propriedade. Revista da Fundação Escola Superior do Ministério Publico do Distrito Federal e Territórios. no 10, ano 5, p. 43-51, 1997.

CORTEZ, Antonio Celso Aguilar. Obrigações propter rem (visão contemporânea). Dissertação de mestrado em Direito Civil, Faculdade de Direito da Universidade de São Paulo, 2004.

DANTAS, F. C. de San Tiago. O conflito de vizinhança e sua composição. Rio de Janeiro, 1939.

DERANI, Cristiane. Direito ambiental econômico. São Paulo: Max Limonad, 1997.

DIAS, José de Aguiar de. Da responsabilidade civil. 11 ${ }^{\text {a }}$ ed., Rio de Janeiro: Editora Renovar, 2006.

DIDIER JR., FREDIE. A função social da propriedade e a tutela processual da posse. In: Novo código civil: questões controvertidas - direito das coisas. Coord. Luiz Delgado, Jones Figueirêdo Alves, São Paulo: Método, 2008.

DINIZ, Maria Helena. Curso de direito civil brasileiro. $2^{\circ}$ Vol., $18^{a}$ ed., São Paulo: Saraiva, 2003.

DINIZ, Maria Helena. Curso de direito civil brasileiro. $4^{\circ}$ Vol., $23^{\mathrm{a}}$ ed., São Paulo: Saraiva, 2008.

DINIZ, Maria Helena. Lei de locações de imóveis urbanos comentada. $8^{\circ}$ ed., São Paulo: Saraiva, 2006.

ELIAS FILHO, Rubens Carmo. As despesas do condomínio edilício. São Paulo: Revista dos Tribunais, 2005.

FARIA, Luiz Alberto Gurgel de. Código tributário nacional comentado. $4^{\mathrm{a}}$ ed., coord. Vladimir Passos de Freitas, São Paulo: Revista dos Tribunais, 2007. 
FERNANDES, Cintia Estefania. IPTU texto e contexto. São Paulo: Quartier Latin do Brasil, 2005.

FERNANDES, Luís A. de Carvalho. Lições de direitos reais. $5^{\text {a }}$ ed., Lisboa: Quid Juris, 2007.

FRANCO, J. Nascimento. Condomínio. 5a ed., São Paulo: Revista dos Tribunais, 2005.

FURLAN, Valéria Cristina Pereira. Imposto predial e territorial urbano. São Paulo: Malheiros Editores, 2000.

FUSARO, Andréa. Obbligazione <<propter rem〉> ed onere reale. Digesto. $4^{\mathrm{a}}$ ed., Discipline Privatistiche, Sezione Civile, Utet.

GATTI, Edmundo. Derechos reales - teoría general. Buenos Aires: Lajouane, 2006.

GERI, Lina Bigliazzi. Oneri reali e obbligazioni propter rem. Milano: Giuffré, 1984.

GOMES, Orlando. Direitos reais. 19ª ed., Rio de Janeiro: Editora Forense, 2008.

GOMES, Orlando. Obrigações. 13ª ed., Rio de Janeiro: Editora Forense, 2000.

GONÇALVES, Carlos Roberto. Direito civil brasileiro - direito das coisas. V Vol., São Paulo: Editora Saraiva, 2007.

GONDINHO, André Pinto da Rocha Osório. Direitos reais e autonomia da vontade (o princípio da tipicidade dos direitos reais). Rio de Janeiro: Renovar, 2000.

JUSTO, A. Santos. Direitos reais. Coimbra: Coimbra Editora, 2007.

KONDER, Carlos Nelson. Enriquecimento sem causa e pagamento indevido. In: Obrigações: estudos na perspectiva civil-constitucional. Coord. Gustavo Tepedino, Rio de Janeiro: Renovar, 2005. 
LACERDA DE ALMEIDA, Francisco de Paula. Direito das cousas. Rio de Janeiro: J. Ribeiro dos Santos, 1908.

LEMOS, Patrícia Faga Iglecias. Meio ambiente e responsabilidade civil do proprietário: análise do nexo causal. São Paulo: Revista dos Tribunais, 2008.

LOPEZ, Teresa Ancona. Nexo causal e produtos potencialmente nocivos: a experiência brasileira do tabaco. São Paulo: Quartier Latin, 2008.

LÔBO, Paulo Luiz Netto. Teoria geral das obrigações. São Paulo: Saraiva, 2005.

MACHADO, Paulo Afonso Leme. Direito ambiental brasileiro. $14^{\mathrm{a}}$ ed., São Paulo: Malheiros Editores, 2006.

MACHADO, Hugo de Brito. Curso de direito tributário. 26a ed., São Paulo: Malheiros Editores, 2005.

MACHADO, Hugo de Brito. Comentários ao código tributário nacional. Vol. II, São Paulo: Editora Atlas S.A., 2004.

MAIA, Antonio Carlos Cavalcanti. Responsabilidade por danos. Inexistência de obrigação propter rem... Revista Forense. Vol. 100, n. 376, p. 183-190, Rio de Janeiro, 2004.

MAIA, Paulo Carneiro. Obrigação propter rem. Revista dos Tribunais. $\mathrm{n}^{\circ}$ 315; Enciclopédia Saraiva do Direito, Ed. Saraiva, 1980, vol. 55.

MALUF, Carlos Alberto Dabus e MARQUES, Márcio Antero Motta Ramos. Condomínio edilício no novo código civil. São Paulo: Saraiva, 2004.

MALUF, Carlos Alberto Dabus. A propriedade no código civil de 2002: principais limitações e renúncia. In: Novo código civil: questões controvertidas - direito das coisas. Coord. Luiz Delgado, Jones Figueirêdo Alves, São Paulo: Método, 2008. 
MANNA, Lorena. Le obbligazioni propter rem. Padova: CEDAM, 2007.

MAXIMILIANO, Carlos. Condomínio. 5ª ed., Rio de Janeiro: Freitas Bastos, 1961.

MENEZES CORDEIRO, Antonio. Direito reais. Lisboa: Lex, 1993.

MESQUITA, Manuel Henrique. Obrigações reais e ônus reais. Coimbra: Livraria Almedina, 2003.

MESSINEO, Francesco. Manuale di diritto civile e commerciale. $9^{a}$ ed., Milão: Editora Dott. A. Giuffré, 1965.

MIRANDA, Pontes de. Tratado de direito privado. vol. 12, $3^{\text {a }}$ ed., São Paulo: Revista dos Tribunais, 1984.

MOLINARIO, Alberto Domingo. De las relaciones reales. Buenos Aires: Editora La Universidad, 2006.

MONTEIRO, Washington de Barros. Curso de direito civil - direito das coisas. $37^{\mathrm{a}}$ ed., São Paulo: Saraiva, 2003.

MOREIRA ALVES, José Carlos, Direito romano, $6^{\text {a }}$ ed., Rio de Janeiro: Forense, 2000.

OLIVA, Milena Donato. A responsabilidade do adquirente pelos encargos condominiais na propriedade horizontal. Revista Trimestral de Direito Civil. Vol. 26, Rio de Janeiro: Editora Padma, p. 67-105, 2006.

OLIVEIRA ASCENSÃO, José de. Direito civil. Reais. $5^{\text {a }}$ ed., Coimbra: Coimbra Editora, 2000

PENTEADO, Luciano de Camargo. Direito das coisas. São Paulo: Editora Revista dos Tribunais, 2008. 
PEREIRA, Caio Mário da Silva. Instituições de direito civil. Vol. II, 15 a ed., Rio de Janeiro: Editora Forense, 1997.

PEREIRA, Caio Mário da Silva. Instituições de direito civil. Vol. IV, $14^{\mathrm{a}}$ ed., Rio de Janeiro: Editora Forense, 2000.

PERLINGIERI, Pietro. Perfis do direito civil: introdução ao direito civil constitucional. $3^{\text {a }}$ ed., Rio de Janeiro: Renovar, 2007.

PODESTÁ, Fábio Henrique. Obrigações Propter Rem. Revista da Faculdade de Direito das Faculdades Metropolitanas Unidas de São Paulo. Vol. 9, nº 12, p. 245-253, São Paulo, 1995.

RIZZARDO, Arnaldo. Direito das coisas: Lei $\mathbf{n}^{\mathbf{0}}$ 10.406, de 10.01.2002. Rio de Janeiro: Forense, 2006.

RODRIGUES, Silvio. Direito civil - parte geral das obrigações. $2^{\circ}$ Vol., $26^{a}$ ed., São Paulo: Saraiva, 1998.

RODRIGUES, Silvio. Direito civil - direito das coisas. $5^{\circ}$ Vol., $28^{a}$ ed., São Paulo: Saraiva, 2007.

SALLES, Carlos Alberto de. Propriedade imobiliária e obrigações "propter rem" pela recuperação ambiental do solo degradado. Revista de Direito Ambiental, no 34, p. 9-18, São Paulo, 2004.

SANTOS, Flauzilino Araújo dos. As despesas comuns e a garantia de funcionamento. Disponível em: <http://www.irib.org.br/biblio/boletimel2474.asp> Acesso em 7 de agosto de 2008.

SANTOS, J. M. DE CARVALHO. Repertório enciclopédico do direito brasileiro. Vol. XXXV, Rio de Janeiro: Editor Borsoi. 
SARMENTO FILHO, Eduardo Sócrates Castanheira. A responsabilidade pelo pagamento de cotas condominiais no regime da propriedade horizontal. Revista dos Tribunais. Vol. 767, p. 86-92, São Paulo, 1999.

SERPA LOPES, Miguel Maria de. Curso de direito civil - obrigações em geral. Vol. II, $4^{a}$ ed., Rio de Janeiro: Livraria Freitas Bastos, 1966.

SERPA LOPES, Miguel Maria de. Curso de direito civil - direito das coisas. Vol. VI, $2^{\mathrm{a}}$ ed., Rio de Janeiro: Livraria Freitas Bastos, 1962.

SILVA, José Afonso da. Direito ambiental constitucional. $4^{\mathrm{a}}$ ed., São Paulo: Malheiros Editores, 2003.

SILVA, Roberta Mauro e. Relações reais e relações obrigacionais: propostas para uma nova delimitação de suas fronteiras. Obrigações: estudos na perspectiva civilconstitucional. Coord. Gustavo Tepedino, Rio de Janeiro: Renovar, 2005.

TEPEDINO, Gustavo. Multipropriedade imobiliária. São Paulo: Saraiva, 1993.

TEPEDINO, Gustavo. Obrigações: estudos na perspectiva civil - constitucional. Rio de Janeiro: Renovar, 2005.

TEPEDINO, Gustavo. Código civil comentado: direito das obrigações: artigo 233 a 420. Vol. IV, coord. Álvaro Villaça Azevedo, São Paulo: Atlas S.A., 2008.

TRABUCCHI, Alberto. Istituzioni di diritto civile. 39ª ed., Padova: CEDAM, 1999.

VALERA, Edgardo. Obligaciones propter rem. Revista del colegio de abogados de la plata. $n^{\circ} 61$, p. 127-147, La Plata, 2000.

VARELA, Antunes. Direito das obrigações. Rio de Janeiro: Editora Forense, 1977.

VENOSA, Sílvio de Salvo. Direito civil: direitos reais. Vol. 5, $8^{\text {a }}$ ed., São Paulo: Editora Atlas S.A., 2008. 
VENOSA, Sílvio de Salvo. Direito civil: teoria geral das obrigações. Vol. 2, $8^{\mathrm{a}}$ ed., São Paulo: Editora Atlas S.A., 2008.

VÍTORES, Germán de Castro. La obligación real en el derecho de bienes. Madrid: Centro de Estudios Registrales, 2000.

WALD, Arnoldo. Curso de direito civil brasileiro - direito das coisas. $9^{a}$ ed., São Paulo: Revista dos Tribunais, 1993.

ZANNONI, Eduardo A. Elementos de la obligación. Buenos Aires: Editorial Astrea, 1996. 